\title{
14. JURASSIC LIMESTONES OF THE SEAWARD EDGE OF THE MAZAGAN CARBONATE PLATFORM, NORTHWEST AFRICAN CONTINENTAL MARGIN, MOROCCO ${ }^{1}$
}

\author{
Torsten Steiger, Universitäts-Institut für Paläontologie und Historische Geologie, Munich \\ and \\ Lubomir F. Jansa, Bedford Institute of Oceanography ${ }^{2}$
}

\begin{abstract}
During Leg 79 Jurassic limestones were recovered at four sites drilled at the front of the Mazagan Plateau, making it possible to reconstruct depositional conditions at the outer edge of the continental margin. At Site 544, red Oxfordian limestones overlie red continental clastics and Paleozoic basement. The limestones are composed of cyanobacterial crusts grading upward into bioclastic grainstones and wackestones. Early lithification is evidenced by the development of hardgrounds and cavities as the depositional environment deepened and the sedimentation rates decreased.

At Site 545 Jurassic limestones occur as constituents of debris flows, which are embedded with Miocene nannofossil oozes. The rock fragments were derived from oolitic shoals, coral bioherms, and deeper shelf deposits. Calpionellids indicate a Tithonian to Early Cretaceous age for the clasts. Some of these limestone breccias have a complex history. The first fragmentation occured during the Early Cretaceous, the second during the Late Cretaceous, and the final emplacement happened during the late Miocene. In situ limestones were encountered beneath the Cenozoic cover at Site 545 and indicate the presence of a retreating carbonate platform during the Late Jurassic with a downfaulted platform edge. The uppermost portion is composed of brecciated lagoonal carbonates forming a periplatform talus in front of the developing Mazagan Escarpment. The oldest sediments recovered at Site 545 are sandy slope deposits of Middle Jurassic age. In the middle of the section, dolomitic stromatolites indicate brief regressive intervals. The presence of a poorly lithified talus at the edge of the platform confirms the initial drowning phase of the carbonate platform, which occurred before the final cementation of the Jurassic platform deposits.

At Site 546, located upon a salt dome, two fragments of Jurassic oolitic limestone were embedded into middle Miocene calcareous ooze. Their presence marks the tail of a debris flow.

Site 547 , which is located in a small structural sub-basin at the base of the margin, demonstrates that marine deposition started with the development of stromatolites overlying (?)Triassic continental red beds. A rapid change to pelagic conditions is documented by the deposition of micritic nodular limestones. Black shale interlayers suggest that restricted conditions occasionally developed in the sub-basin, which was filled by sandy and calcareous clastics during the Middle Jurassic. In the Oxfordian, a carbonate ramp was constructed, composed of in situ crusts and proximal breccias that indicate the largest extension of the Mazagan carbonate platform. The upper part of the Jurassic limestone sequence at Site 547 contains nodular limestones and pelagic wackestones, frequently interlayered with calcareous turbidites. The upward change in limestone composition suggests that the shallow-water platform edge retreated landward during the late Tithonian and Early Cretaceous as the Mazagan Escarpment was formed.
\end{abstract}

\section{INTRODUCTION}

Leg 79 was drilled off the northwestern part of the Mazagan Plateau. The area explored covers $160 \mathrm{~km}^{2} \mathrm{lo}-$ cated at the outer continental margin off Morocco. Four sites were located on the deep slope in front of the Mazagan Escarpment (Fig. 1). The shallowest Site 545 was spudded in a water depth of $3150 \mathrm{~m}$ and the deepest Site 547 at a depth of $3940.5 \mathrm{~m}$. The sites were located close together to study the complexity and the dynamics of the carbonate platform slope, the nature of the underlying basement, the origin, character, and age of the evaporites, the paleocirculation and depositional history of the Cenozoic sedimentary cover, and, finally, the role of tectonics in the evolution of the outer continental margin.

1. Site 544 is located on the top of a morphologically elevated structure which was interpreted from dredging

\footnotetext{
${ }^{1}$ Hinz, K., Winterer, E. L., et al., Init. Repts. DSDP, 79: Washington (U.S. Govt. Printing Office).

2 Addresses: (Steiger)Universităts-Institut für Paläontologie und Historische Geologie, Richard-Wagner Str. 10/11, 8000 München 2, Federal Republic of Germany; (Jansa) Geological Survey of Canada, Bedford Institute of Oceanography, Box 1006, Dartmouth, Novia Scotia B2Y 4A2 Canada.
}

results (Renz et al., 1975) and multichannel seismic data (Hinz et al., 1982) as a block of igneous basement. The subsequent study of the area by the French oceanographic vessel Jean Charcot shows that a plateau approximately $14 \mathrm{~km}^{2}$ in area and 3000 to $3500 \mathrm{~m}$ deep can be distinguished from the recent Mazagan Plateau. Site 544 is situated on the northwest margin of this smaller plateau, at a water depth of $3617 \mathrm{~m}$, on the upper slope of the auxiliary escarpment bordering the structure in a southwest-northeast direction, parallel to the larger Mazagan Escarpment.

2. Site 545 was located about $12 \mathrm{~km}$ south-southeast of Site 544 below the modern Mazagan Escarpment. Drilling started at $3150 \mathrm{~m}$ water depth. Layers of Jurassic clasts embedded in Miocene calcareous oozes as well as in situ carbonate platform sediments of Jurassic age were recovered. Unfortunately, the carbonate sequence was not completely drilled, for technical reasons, and drilling was terminated in ?Middle Jurassic sandy limestones.

3. Site 546 was planned in order to confirm the presence of a salt dome predicted by geophysical surveys. The seafloor was encountered at $3992 \mathrm{~m}$. Before the salt was reached, a short sequence of mixed lithologies was 


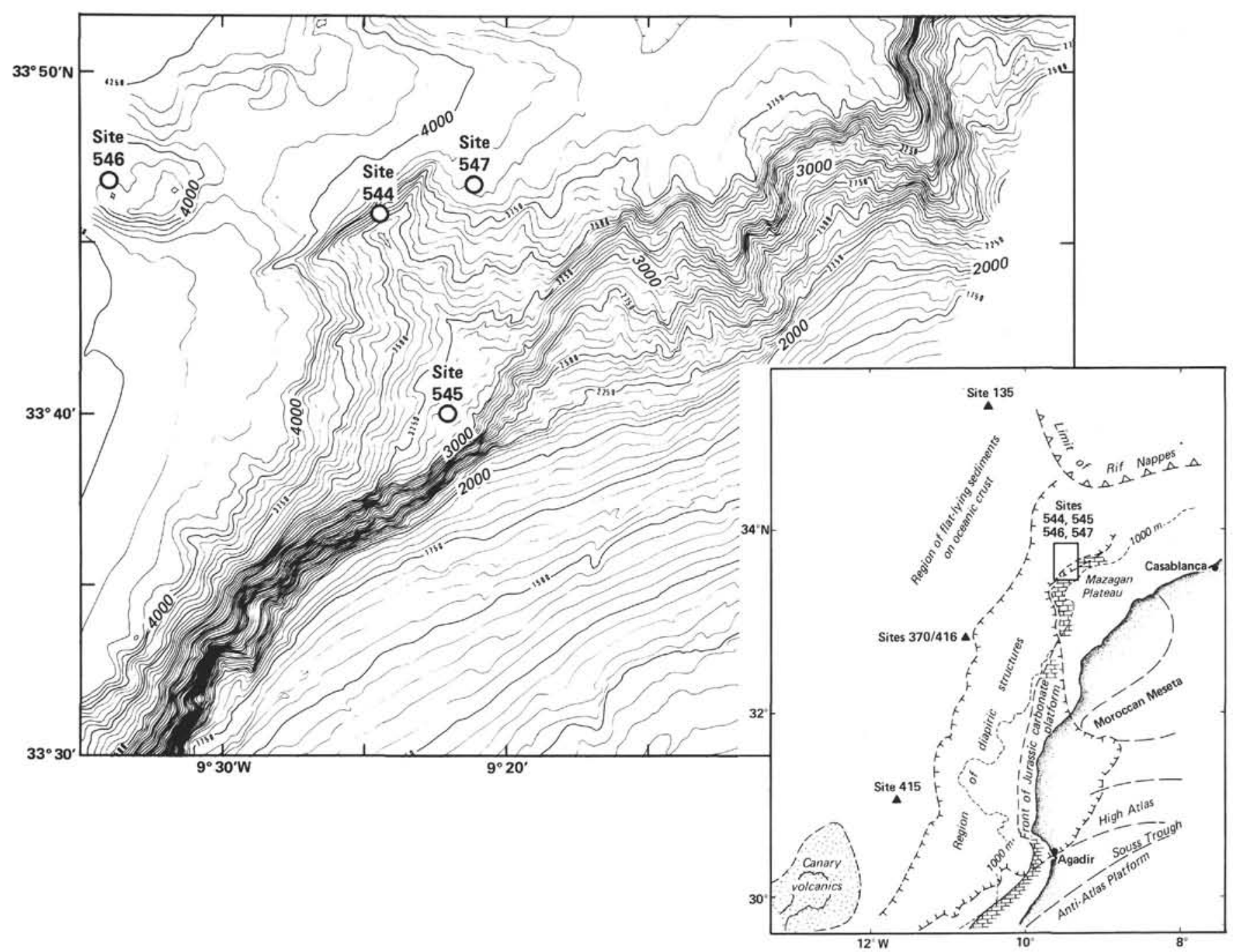

Figure 1. Location and bathymetry of Sites 544-547, from Auzende et al., this volume.

recovered. This sequence contains Jurassic limestones derived from the platform as a result of Miocene gravity flows. Site 546 is about $10 \mathrm{~km}$ west of Site 544 . Between both sites there exists a basin with a water depth of $4000 \mathrm{~m}$.

4. Site 547 was drilled $12 \mathrm{~km}$ north of Site 545 and 5 $\mathrm{km}$ east-northeast of Site 544 at $3490.5 \mathrm{~m}$ water depth. Seismic data indicate that the hole is situated in a small structural sub-basin between the Mazagan Escarpment and the basement ridge on which Site 544 was located. Jurassic and lowermost Cretaceous basinal limestones were found. Drilling was stopped in continental red beds of unknown thickness.

Additional information about the characteristics of the Jurassic-lowermost Cretaceous limestones at the Moroccan continental margin has been provided by dredging at the Mazagan Escarpment (Vema dredge: Renz et al., 1975; Wissmann and von Rad, 1979), DSDP Legs 41 and 50 (Lancelot, Seibold, et al., 1978; Lancelot, Winterer, et al., 1980), and by the CYANA dives (CYAMAZ, 1982: CYAMAZ group, this volume; Auzende et al., this volume).

In this chapter we present results of studies of 300 thin sections prepared from the Leg 79 cores. We con- centrate on the composition of the Jurassic-Lower Cretaceous limestones, their depositional conditions, and the sedimentary dynamics generated by tectonic movements and biogenic buildup in order to reconstruct the paleogeographic development of the Leg 79 area on the outer Mazagan Plateau. The broader relationship between the sites and onshore carbonate platforms in the context of the development of the Northwest African margin is discussed in more detail by Jansa et al. (this volume).

In this chapter, limestones are classified after Dunham (1962), Embry and Klovan (1972), Folk (1959), and Logan and Semeniuk (1976). For quantitative particle estimates the charts of Bacelle and Bosellini (1965) were used. The methods for analysis and interpretation of environmental conditions were influenced by Flügel (1978, 1982).

\section{SITE 544}

The Paleozorc gneiss basement encountered at this site is covered by a sedimentary sequence $184 \mathrm{~m}$ thick. The basement is unconformably overlain by $45 \mathrm{~m}$ of continental red beds which are followed by $35.5 \mathrm{~m}$ of reddish 
brown and yellowish brown mottled limestones. The limestones show minimum variation in general lithology, suggesting deposition in very similar environments. The most characteristic constituents are cyanobacterial oncoids and pelmicritic crusts. Hardgrounds and solution cavities that are also present contain early diagenetic cements and highly recrystallized internal sediments. Nevertheless, environmentally significant minor changes occur in the limestone composition and make it possible to separate a few distinct facies types.

The red limestone is composed of biogenic remains, nonskeletal components, and crusts. The shape and preservation of the skeletal particles indicate that they are the result of natural decomposition rather than of abrasion under high-energy conditions. Some of the nonskeletal components, such as oncoids and coated grains, were influenced by biogenic carbonate precipitation generated by the activity of cyanobacterians (compare Krumbein, 1979); others are strictly mechanically reworked intraclasts. Terrigenous components are represented by angular quartz grains randomly distributed in a micritic matrix.

\section{Biota}

\section{Crinoids}

The most characteristic sessile biota in the sedimentary environment is crinoids. Their columnals are frequently separated and concentrated in patches of wackestone and grainstone. The crinoids belong to the Pentacrinus group, showing typical pentamere sections. Parts of intact stems are also observed. Crinoid remains, as well as fragments of other echinoderms, are generally overgrown by sessile foraminifers and coated by bacterial micrite (Pl. 1, Fig. 1). Some columnals are not encrusted and have been subjected to neomorphic syntaxial calcitization (Pl. 1, Fig. 2).

\section{Sponges}

Calcitized siliceous sponges of the hexactinellid group are sparsely distributed in crustose parts of the limestone sequence. Siliceous sponge fragments are heavily overgrown by cyanobacterial crusts and sessile miliolid foraminifers. Sponge debris is occasionally found as part of intraclasts, together with ostracodes and "filaments" (pelagic bivalves). Uncoated skeletons are rarely seen in micritic sediments. None of the sponges was found to be in situ (Pl.1, Fig. 3).

\section{Corals}

Fragments of solitary corals are rare (PI. 1, Fig. 4). The walls of the corals show solution-cavity fill of microgranular calcite and fine-grained internal sediments which are slightly coarsened by neomorphism. All coral fragments are coated by micrite and sessile miliolid foraminifers.

\section{Sessile Foraminifers}

Sessile foraminifers are very important for the interpretation of the sedimentary environment of the red limestones. They occur as encrustations in cyanobacterial- foraminiferal oncoids and grains. Their tests are attached to different kinds of early lithified surfaces (Pl. 1, Figs. 5, 6).

\section{Serpulids}

Calcite tubes of serpulids are frequently rimmed by micrite occuring as part of cyanobacterial oncoids. Serpulids are also found in place - attached beneath the roofs of subsurface cavities (Pl. 2, Fig. 1).

\section{Bryzoans and Brachiopods}

Tentaculate organisms are not frequent and are ecologically insignificant. Small clasts of bryozoan skeletons are rarely embedded in bioclastic wackestones. Perforate brachiopod shells are seldom found, either in accumulations of "filaments" or as nuclei of cyanobacterial oncoids. No brachiopod was observed in place or even with both shells connected.

\section{Vagile Benthic Foraminifers}

The group of vagile benthic foraminifers is composed of miliolids, nodosariids, rotaliids, and calcareous agglutinating forms. Among the miliolids, Opthalmidium and Nodophthalmidium (Pl. 2, Fig. 2) are most common. Most vagile miliolids are restricted to the bioclastic wackestone facies in the upper part of the sequence. The dominant nodosariids are Lenticulina (Pl. 2, Fig. 3) and uniserial forms (Pl. 2, Fig. 4) of Dentalina and Pseudonodosaria groups. Rotaliids are represented by Spirillina (Pl. 2 Fig. 5) and Trocholina (Pl. 2, Fig. 6). Agglutinating forms are Ammobaculites (Pl.3, Fig. 1) and Rheophax (Pl. 3, Fig. 2). Ammobaculites is relatively common in the bioclastic wackestone facies and uses Ophthalmidium tests for the construction of the wall.

\section{Bivalves and Gastropods}

Benthic bivalves are never seen in life position. All shells are transported and commonly encrusted by bacterial micrite or miliolid foraminifers. Gastropods occur rarely throughout the section; they are not limited to a particular facies type. Complete shells are often enclosed as nuclei of cyanobacterial oncoids (Pl.3 Fig. 4). The shells are replaced by blocky calcite crystals.

\section{Ostracodes}

Shells of ostracodes are embedded as single or double valves (PI. 3, Fig. 5). Double-valved carapaces are easily recognized by their internal calcite cement (Pl. 2, Fig. 5). Ostracodes occur throughout the sequence, but are most common in the wackestone facies.

\section{Echinoids}

Echinoids are rare in the Site 544 limestones, but one whole skeleton that was found in the section signifies calm depositional intervals.

The entire limestone sequence of Site 544 contains open sea nektonic and planktonic organisms.

\section{Ammonites and Aptychi}

Ammonites are encountered throughout the limestones, predominantly as small juvenile shells, mostly in 
the centers of cyanobacterial oncoids (Pl. 3, Fig. 5). Shells of adult ammonites are rare and often abraded (Pl. 3, Fig. 6). Like gastropod walls, ammonite walls are replaced by microgranular sparry calcite. Phragmocones were not dissolved on the seafloor but after burial. Aptychi are very rare. The few aptychus fragments are enclosed in cyanobacterial oncoids (Pl. 4, Fig. 1).

\section{Protoglobigerinids and "Saccocoma"}

The Late Jurassic cenozone fossils used in the Tethyan stratigraphy are also present in the outer Mazagan carbonate platform. Foraminifers of the Protoglobigerina group are very rare and restricted to the upper part of the sequence (Core 554A-13). Two Saccocomalike fragments occur at the top and at the base of the red limestones (Pl. 3, Fig. 4).

\section{Pelagic Bivalves}

In contrast to the scarcity of protoglobigerinids, "Saccocoma," and radiolarians, shells of pelagic bivalves ("filaments") are very common. The thin and undulose shells are often concentrated into coquinas, and most are encrusted by cyanobacterial micrite (Pl. 4, Fig. 3). Shells rimmed by micrite have a preserved platy microstructure. Uncoated shells found in microgranular internal sediments and in micritic wackestones are overgrown by neomorphic syntaxial calcite.

\section{Non-skeletal Sedimentary Particles Generated by Carbonate Cementation and Sediment Binding}

\section{Cyanobacterial Oncoids}

Skeletal particles and intraclasts are very commonly coated by fine-grained micrite (Pl. 4, Fig. 3). The micrite coats are composed of numerous thin layers, which in plane light have the appearance of a thick coating. Most micrite rims have up to 10 laminae. Maximum thickness of the entire cortex is $0.5 \mathrm{~mm}$ but normally ranges from 0.1 to $0.2 \mathrm{~mm}$. Skeletal debris is frequently embedded between the laminae. Although coccoliths have not been found in the micrite, these components resemble the "pelagic ooids" by Jenkyns (1972). "Pelagic oolites" are common in Tethyan Upper Jurassic limestones (Bernoulli and Jenkyns, 1974). Because of the skeletal debris included in the micrite cortex the components found in Site 544 must be regarded as micritic oncoids (Peryt, 1981; Flügel, 1982). Their texture is similar to the "tuberoids" known from epicontinental siliceous sponge buildups (Fritz, 1958; Flügel and Steiger, 1981). Micritic oncoids are also described from Lower Cretaceous calcareous turbidites south of the Mazagan carbonate platform (Schlager, 1980). Because the micritic oncoids grow as a result of the carbonate precipitation and sediment binding by cyanobacteria (Krumbein, 1979; Riding, 1979) we use the term "cyanobacterial oncoid" for their description.

\section{Cyanobacterial Forminiferal Oncoids}

Irregular nodules composed of cyanobacterial crusts and sessile foraminifers which enclose mollusk shells, echinoderms, cyanobacterial oncoids, or composite nu- clei occur in all facies types. The sessile miliolid foraminifers are responsible for the irregular internal fabric of these components. Micritic sediment which alternates with cyanobacterial rims is characterized by a brownish color. This suggests a higher Fe content, or layers rich in organic matter. Foraminifers are frequently the initial encrusting part during the development of the oncoid. The cyanobacterial foraminiferal oncoids are mostly present in bioclastic facies (Pl. 4, Fig. 5).

\section{Intraclasts}

Subangular to angular intraclasts result from fragmentation of consolidated or partially lithified sediment. Because rounded intraclasts are missing at Site 544, long transport distances must not be assumed. Maximum size of the intraclasts is about $5 \mathrm{~cm}$, but some of them could be larger than the core diameter. Intraclasts are frequently overgrown by cyanobacterial micrite and crusts (Pl. 4, Fig. 6). Smaller intraclasts also form the nuclei of cyanobacterial oncoids or cyanobacterial foraminiferal oncoids.

\section{Cavities and Internal Sediments}

Cavities are common in the Site 544 limestones. They occur in both the peloidal crust facies and the detrital mud facies, are arranged subhorizontally, and generally have flattened contours in vertical section. In width they range from a few mm up to the diameter of the core, in height up to $5 \mathrm{~cm}$. The cavities are frequently filled with internal sediment, but filling is normally not complete. Some of the cavities must have been interconnected, because internal sediments have reached a uniform level. The well-defined sequence of cavity systems built up one above the other indicates early lithification followed by formation of cavities and subsequent internal sediment filling. Core observations show that individual cavity intervals are up to $10 \mathrm{~cm}$ thick.

Two types of cavities have been recognized:

1. Vugs occuring in pelmicritic crusts, caused by (a) boring and burrowing of the early lithified sediment, (b) selective dissolution of soluble parts of the crusts, and (c) transport of weakly lithified sediment washed out by bottom currents from underneath a firm sedimentary surface.

2. Cavities in detrital sediments. Vugs and interparticle pores of varying size are present in bioclastic wackestones and grainstones. Some of the cavities could have been generated by bioturbation, others may represent shelter cavities formed between and under larger lithoclasts. Cavities were preserved in the detrital sediments because of the low sedimentation rates and slight compaction. Slow bottom currents helped to keep the pores open.

The interiors of both cavity types represent a particular sedimentary and diagenetic environment. The walls and roofs are frequently occupied by serpulids and sessile foraminifers, suggesting a synsedimentary origin for the cavities (Pl. 2, Fig. 1). The internal sediment, occasionally graded (PI. 5, Fig. 2), is composed of biota (pelagic bivalves, echinoderms) and nonbiogenous material (neomorphic micrite). Compared with the normal rock 
matrix, the internal sediment is much coarser. In a final stage the pores and cavities are closed by bladed and blocky calcite cements (Pl. 5, Fig. 4).

\section{Facies Types}

The red limestones at Site 544 display a very complex in situ sedimentary environment. Three major processes controlled the deposition: (1) Strong encrustation by precipitating and sediment-binding cyanobacteria. (2) Fracturing and reworking of the sediments at and immediately below the seafloor; this includes bioturbation, dehydration, and dissolution of the weakly lithified calcareous silt and mud. (3) Nondeposition, producing lithified and encrusted surfaces.

These processes led to the deposition of two major facies types (Fig. 2): the cyanobacterial crusts and the bioclastic grainstones and wackestones.

\section{Cyanobacterial Crust Facies (Cores 544A-14 through 544A-16)}

This facies predominantly shows pelmicritic and pelsparitic composition (Pl. 11, Fig. 2).

\section{Microfacies}

Irregularly laminated bindstone. Each internal layer is terminated by dark micrite and the space between the laminae is made up of pelsparite. Biota and sedimentary particles are frequently incorporated into the crusts: (a) Sessile biota like siliceous sponges, serpulids, and sessile miliolid foraminifers actively participate in forming the crusts. (b) Debris of other sessile organisms like crinoids, but including ostracodes and Globochaete alpina, are also bound. Laterally extended layers of peloidal crusts are uncommon. Because of reworking and, possibly, local dissolution, these early lithified deposits have a patchy distribution. The areas between the crusts are filled with calcareous debris-wackestones and grainstones composed of calcified sponge remains and intensely encrusted intraclasts derived from reworked crusts. Cavities with geopetal infill as described earlier also occur. The peloidal crusts and the adjacent intraclastic allochemical deposits are commonly interlayered with detrital carbonates resulting from increased sedimentary energy and pelagic influx.

\section{Bioclastic Grainstone and Wackestone Facies (Cores 544A-12 through 544A-15)}

Two microfacies types can be distinguished:

\section{Microfacies 1}

Dark patches of bioclastic wackestone composed of large pentracrinid echinoderm ossicles, cyanobacterial oncoids, and pelagic bivalve shells as well as numerous ostracodes and Globochaete alpina. Just above the peloidal crusts are patches of wackestone strongly encrusted by sessile foraminifers and bordered by a typical hardground fabric.

\section{Microfacies 2}

Bioclastic grainstones (Pl. 11, Fig. 2). There are extended pipelike grainstone areas between the wackestone patches. This type of sediment is predominantly composed of cyanobacterial oncoids containing shells of pelagic bivalves, echinoderms, foraminifers, gastropods, and juvenile ammonites. In this grain-supported rock, the interparticle pores are frequently geopetally filled with internal sediment and sparry cements.

In thin section, some of the wackestone patches resemble intraclasts but are not rotated and show no trace of reworking; thus they seem to represent in situ deposits, followed by posterosional accumulation of grainstones. In the uppermost part of the limestone sequence in Site 544 the matrix-supported and grain-supported sediments are interstratified. The dark wackestones are terminated by hardgrounds (Pl. 1, Fig. 6). Here, the carbonate must have been consolidated early, because subsurface cavity systems are preserved just below the bioclastic wackestone layers. The alternating wackestones, grainstones, and hardgrounds indicate intermittent sedimentation. Long periods of nondeposition would also explain the concentrations of pelagic microfossils and the high quantities of cyanobacterial oncoids in the grainstone pipes and layers.

\section{Sedimentary History}

The petrographic study of the 35.5 -m-thick limestone sequence at Site 544 indicates the following development (Fig. 3):

1. The basal $22.5-\mathrm{m}$-thick peloidal crust facies is characterized by the active growth of cyanobacterial crusts. Upward in the section, the in-place cyanobacterial limestone sequence became discontinuous. Reworking of the crusts produced intraclastic wackestone intervals. In the uppermost part of the peloidal crust facies, bioclastic grainstones and wackestones rich in shells of pelagic bivalves indicate the influence of a pelagic regime on deposition. Paleodepths for the formation of the peloidal crusts are unknown, but the faunal assamblage suggests a water depth of approximately 100 to $200 \mathrm{~m}$ (Flügel and Steiger, 1981).

2. The bioclastic facies displays interaction between early lithified muddy sediments and erosional infill by grainstones. In the lower part of the bioclastic facies interval, nonstratified mottled lithologies suggest continuous deposition as well as intense bioturbation and contemporaneous particle transport by bottom currents. Upward in the section, layered sediments accompanied by the formation of hardgrounds indicate reduced sedimentation rates.

In general, the limestones at Site 544 were deposited under low-energy conditions with variable sedimentation rates found on the outer platforms. Shallow-water lagoonal debris did not reach this area. Low sedimentation rates must be seen not as a result of decreasing carbonate production but as a result of intermittent deposition. The erosional fabric is mainly controlled by bioturbation and also by different intensities of lithification. Bottom currents can be strong enough to generate efficient erosion of the weakly lithified muddy carbonates. A remaining problem is to interpret the change from peloidal crust conditions to bioclastic facies, which is accompanied by increased erosional phenom- 


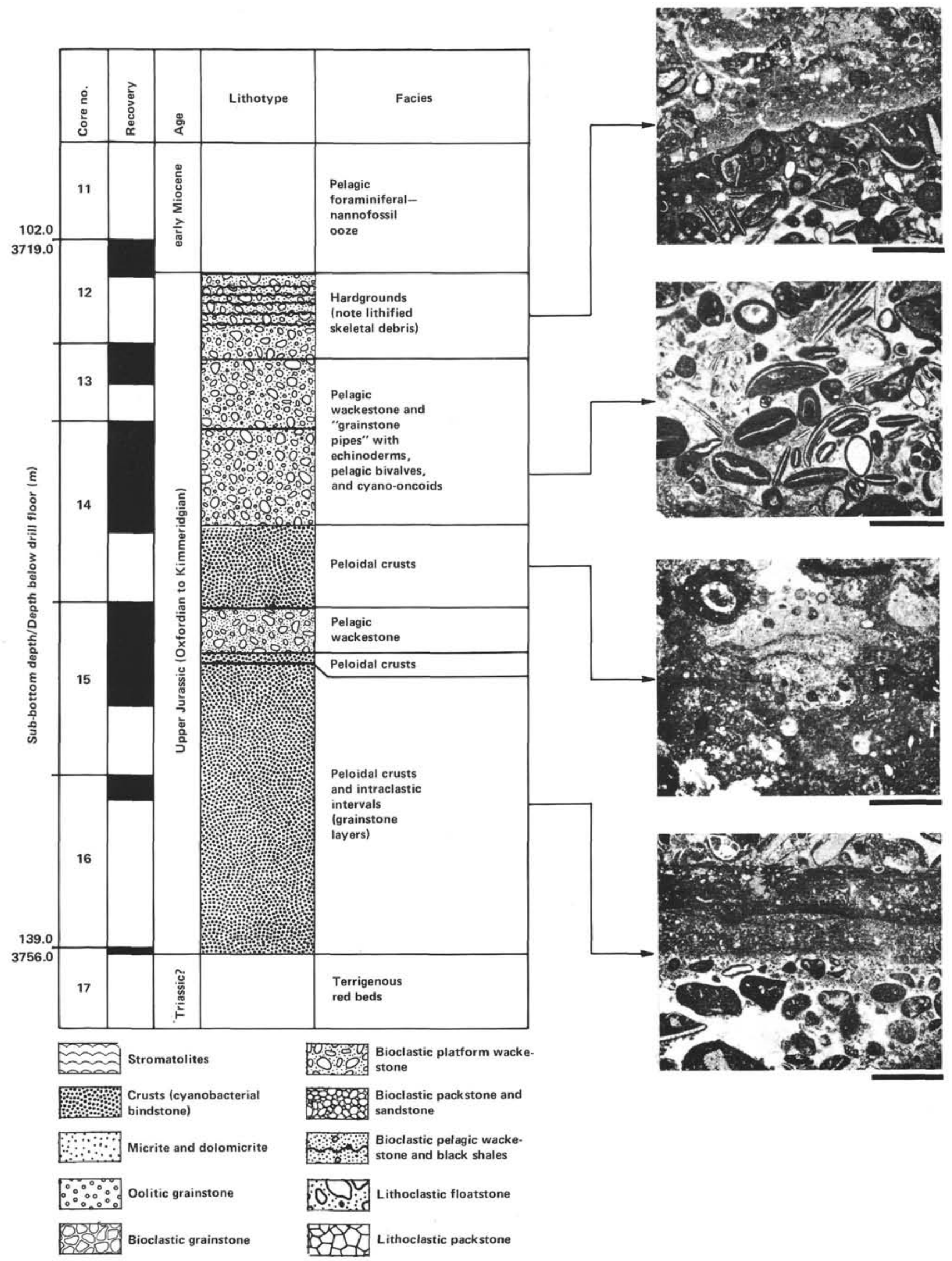

Figure 2. Lithologic column of Hole 544A, Mazagan Plateau, showing the main facies types of the Jurasic limestone sequence. (Scale bar = $1 \mathrm{~mm}$.) 


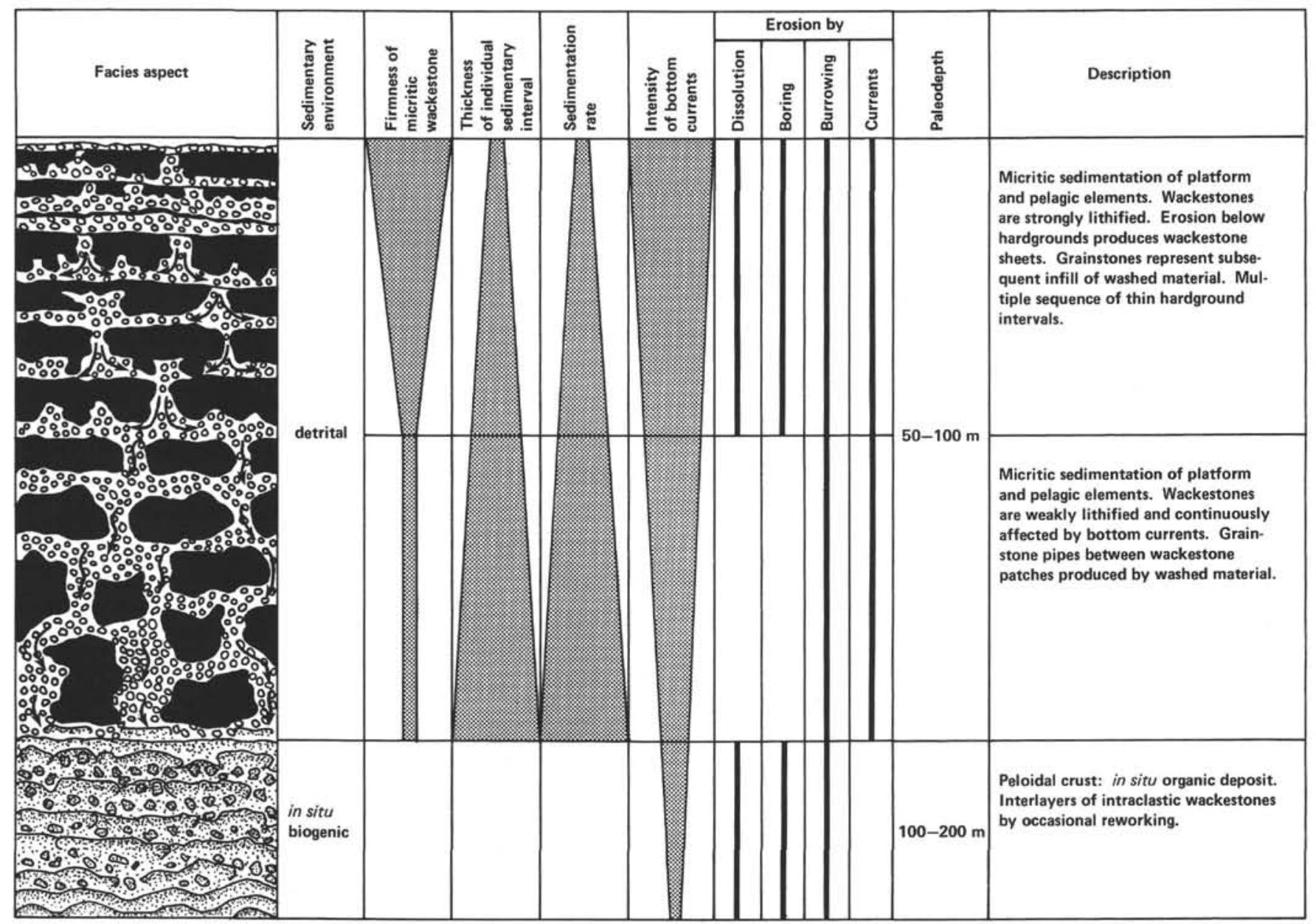

Figure 3. Sedimentological parameters inferred for Site 544 Oxfordian limestones.

ena. This change could suggest a change from calm settling conditions to environments exposed to bottom currents in the open sea. The lithological alterations may be a response to the development of the smaller escarpment which borders the continental block in the northwest (Fig. 14, later). Back-tilting of the tectonic segment could have been responsible for a change of the circulation regime at the depositional site.

\section{SITE 545}

Two different occurrences of Jurassic rocks were recorded in this hole. (1) The first is represented by six layers of limestone lithoclasts deposited by gravity flows and embedded in Pliocene and Miocene pelagic oozes. The lithoclasts consist of mixed lithologies of Upper Jurassic and Upper Cretaceous pelagic and platform deposits. (2) The second occurrence is found as in situ Jurassic carbonate platform sediments, penetrated for about $170 \mathrm{~m}$ (the base of the platform was not drilled). This sequence has been subdivided into (a) shallow-water lagoonal carbonates, $104.8 \mathrm{~m}$ thick, composed of bioclastic grainstones, packstones, and wackestones; (b) sandy limestones and calcareous sandstones, $65.5 \mathrm{~m}$ thick, including oolitic and bioclastic wackestones and packstones. Whereas the upper subunit of this in situ platform sequence could be dated as Late Jarassic, the age and thickness of the lower subunit is unknown. From comparative studies with onshore Jurassic sediments, a Middle Jurassic age is very probable (Michard, 1976; Jansa et al., this volume).

Jurassic Pebbles and Cobbles in Miocene and Pliocene Pelagic Ooze (Cores 10, 11, 15, 16, and 20)

The compostion of the limestone clasts is highly variable. Detailed petrographic study has established the following lithotypes (Fig. 4):

\section{Sponge Facies}

Such deposits, probably derived from sponge buildups, are represented by the following.

1. Bioclastic sponge wackestones occasionally rich in calpionellids.

\section{Microfacies}

Debris of calcitized siliceous sponges (Pl. 6, Fig. 1), coral fragments, clasts of chaetetids, bryozoans, dasycladacean algae (Acicularia sp.), echinoderms, Tubiphytes sp. (PI. 6, Fig. 2), brachiopods, bivalves, benthic foraminifers (Textularia, Lenticulina, Glomospira, Spirillina, Ammobaculites, Trocholina, Nodophthalmidium, Op- 


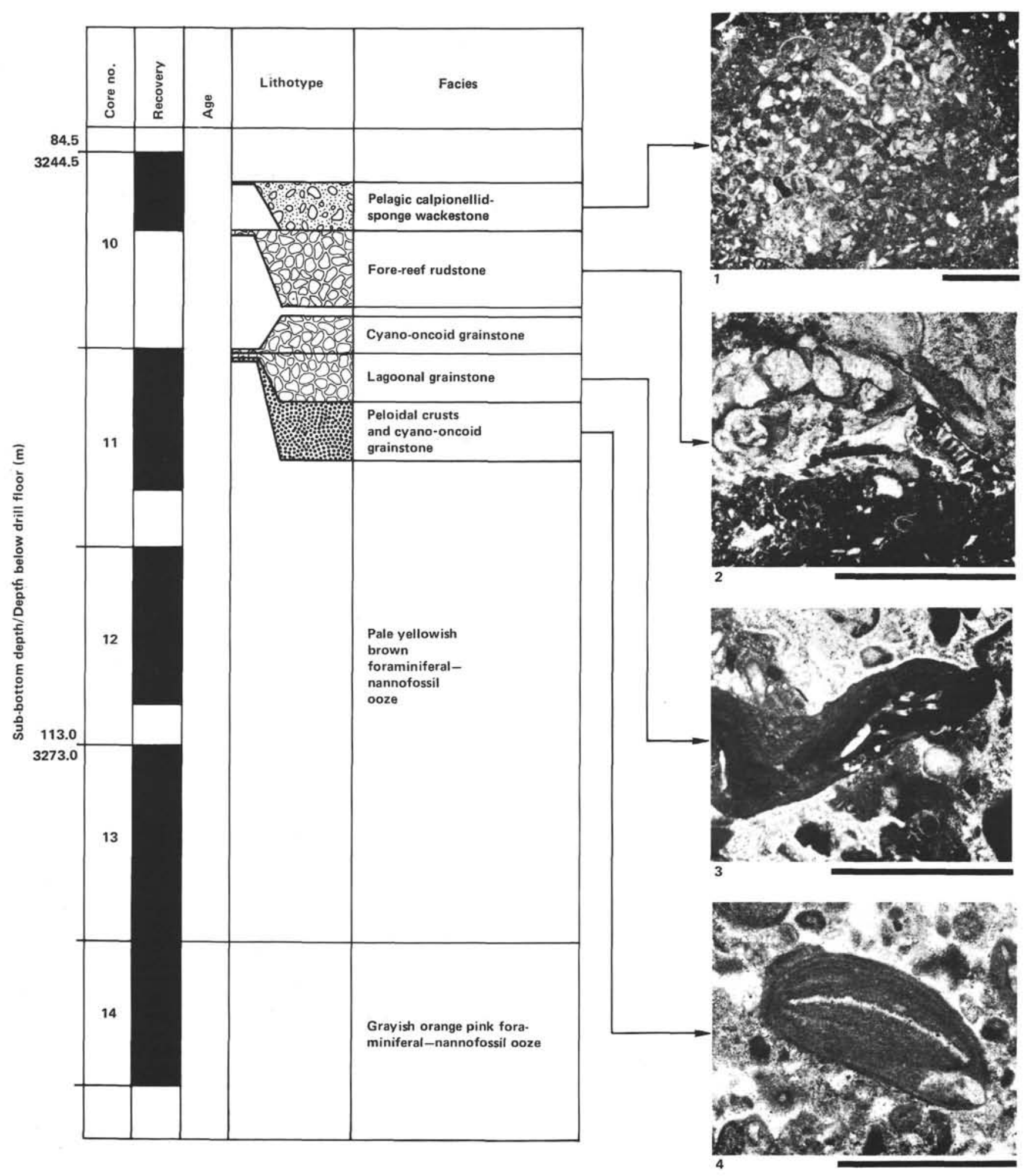

Figure 4. Lithologic column of Site 545, Mazagan Plateau. Predominant facies types of Jurassic limestone pebbles in Miocene gravity flows. Photomicrographs (scale bar, $1 \mathrm{~mm}$ ): (1) bioclastic wackestone with calcitized siliceous sponge; (2) bioclastic rudstone with calcareous algae and coral debris; (3) bioclastic grainstone with Tubiphytes; (4) cyano-oncoid grainstone; (5) ooid grainstone; (6) serpulids in calpionellid-bearing bioclastic wackestone; (7) bioclastic rudstone; (8) strongly encrusted calcitized siliceous sponge. 


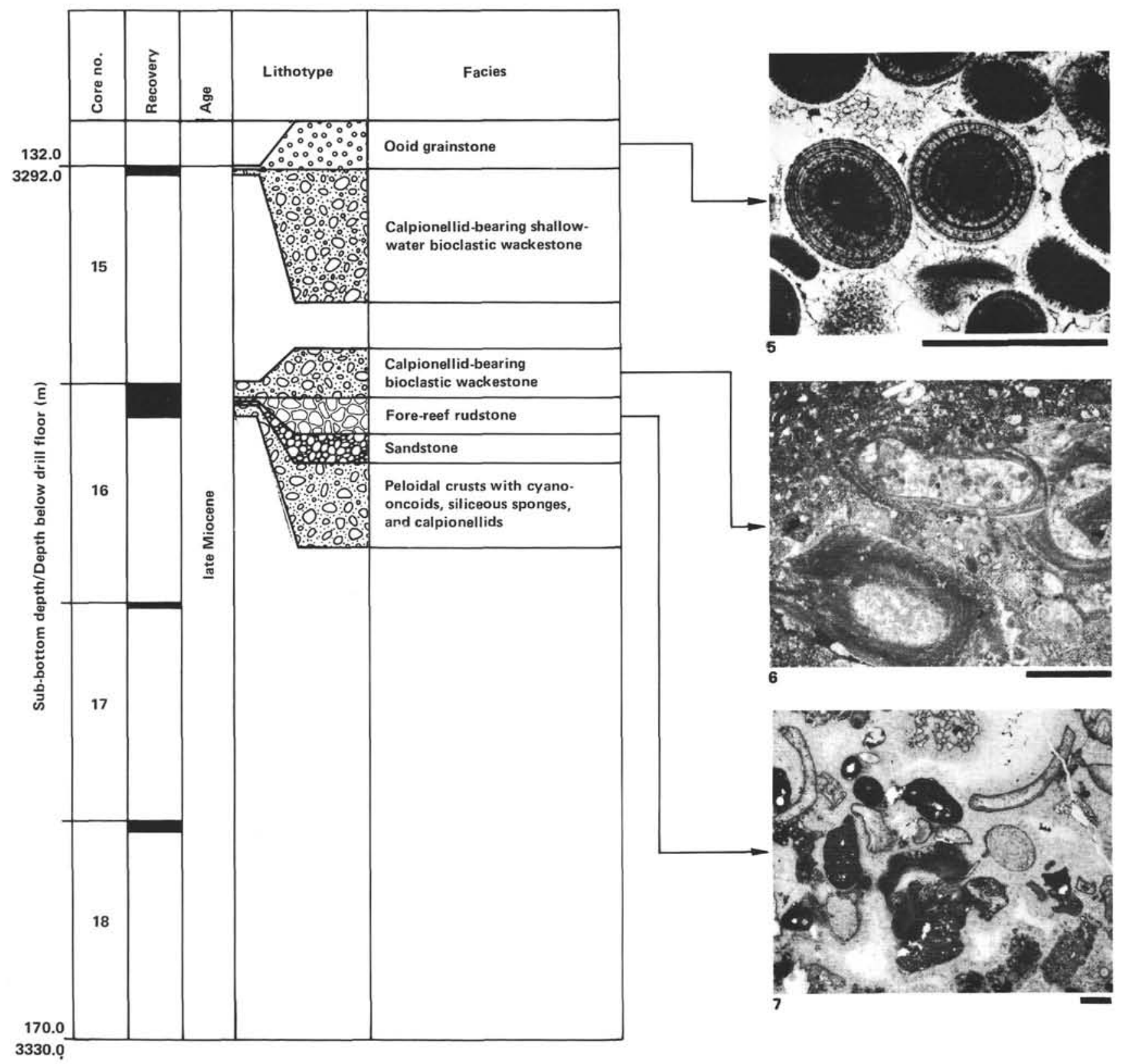

Figure 4. (Continued).

thalmidium), ostracodes; gastropods, ammonites (Pl. 6, Fig. 3), aptychi, and calpionellids float in micritic matrix (Pl. 11, Fig. 3).

2. Bioclastic grainstones and rudstones containing sponge debris and coral reef debris.

\section{Microfacies}

Clasts of calcitized siliceous sponges, corals, chaetetids, bryozoans, gastropods, bivalves, Tubiphytes sp., echinoderms, foraminifers (Trocholina, miliolids, Nautiloculina oolitica Mohler), serpulids, ostracodes, ammonites, and aptychi are cemented by at least two generations of originally fibrous(?) rim cement (Pl. 6, Fig. 4). A blocky cement fills the remaining interparticle pores. The components are generally micritized and altered to cortoids (coated grains; compare Flügel, 1982).

\section{Low-energy Cyanobacterial Oncolitic Wackestones and Peloidal Crusts}

\section{Microfacies}

Cyanobacterial oncoids, small echinoderm remains, foraminifers (Bigenerina, Textularia, Ophthalmidium, nodosariids, Ammobaculites), and peloids float in micritic matrix. Sparry cement occurs in bioturbated areas. Some thin sections show that cyanobacterial oncoids are associated with pelmicritic crusts.

\section{High-energy Oolitic Grainstone Facies}

\section{Microfacies}

Shallow-water high-energy ooids composed of concentric layers are predominant (Pl. 6, Fig. 5). Nuclei of 


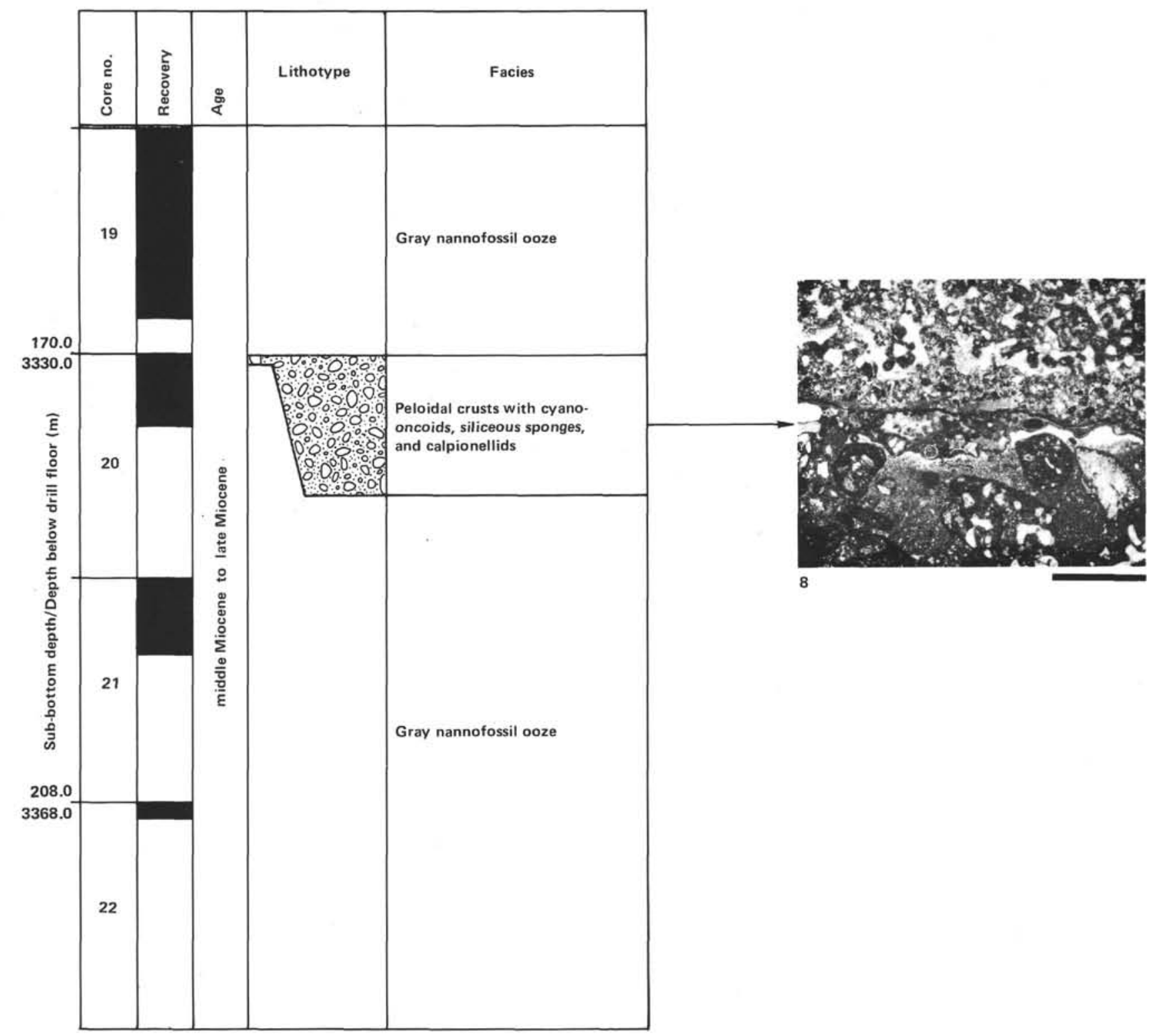

Figure 4. (Continued).

the ooids are remains of dasycladacean algae (Petrascula sp.), coral line algae [Thaumatoporella parvovesiculifera (Raineri)], coral fragments, echinoderms, foraminifers [Trocholina alpina (Leupold), Trocholina elongata (Leupold), Protopeneroplis striata Weynschenk, and Glomospira sp.]. The components were cemented by thin calcite rim cements and later by irregular blocky spar.

For the origin of the rocks it is important to note the high pelagic content in the Jurassic pebbles. In particular, the occurrence of ammonites and aptychi in the grainstones indicates strong mixing of carbonate platform and pelagic biota. The presence of deeper-water siliceous sponges and photic corals supports the conclusion that the reef builders could grow on the same slope on the outer shelf, since the presence of pelagic organisms indicates that there was no reef or structural barrier seaward of the gravity-flow source area.
Most of the resedimented clasts belong to the sponge lithofacies. Jurassic oolites, undetermined sandstones, and Upper Cretaceous breccias (Pl. 6, Fig. 6) are poorly represented. This assemblage agrees with the lithostratigraphic sequence found during CYANA dives $85-90$ (Auzende et al., this volume) south of the Leg 79 drill sites. The pebbles may not have been derived only from the slope above Site 544 . The gravity flows may have come from either south or north, where sponge-crust, calpionellid-bearing material is available at the external segments of the inner carbonate platform.

The Jurassic in situ Carbonate Platform (Cores 56 through 74)

Highly dolomitized grainstones, dolomitic laminites, and near-reef detrital limestones were encountered in the upper $97 \mathrm{~m}$ of the in situ Jurassic platform carbonates. 
However, the uppermost $68 \mathrm{~m}$ could represent proximal resedimented debris accumulated as a periplatform talus (Fig. 5).

\section{Algal Echinoderm Facies (Cores 56 through 63)}

\section{Microfacies}

Grainstones, composed of coral debris (Pl. 7, Fig. 2), calcareous sponges (Pl. 7, Fig. 1), echinoderms, gastropods, bivalves, Tubiphytes sp., Cayeuxia sp., Nipponophycus sp., Thaumatoporella parvovesiculifera (Raineri), dasycladacean algae (Pl. 7, Figs. 3 and 4; e.g., Salpingoporella pygmaea Gümbel), foraminifers (Protopeneroplis striata Weynschenk, Pseudocyclammina lituus Yokoyama), and intraclasts of pelsparite and pelmicrite. The components are cemented by a thin cover of irregularly shaped calcite crystals, most of which are enlarged externally. These types of crystal rims are also developed in biogenic molds that predate dissolution of aragonite shells. Remaining pores are not closed, yielding porosity up to $30-40 \%$. Original porosity is reduced by intense dolomitization. Dolomite rhombs form $5-20 \%$ of the thin section (see Pl. 7, Fig. 3). When present, syntaxial echinoderm cement also contributes to the occlusion of the pores.

\section{Oolitic Facies (Core 64 through Section 545-65-1)}

\section{Microfacies}

Grainstones, composed of concentric ooids (Pl. 8, Fig. 4), coral debris, Tubiphytes sp., gastropods, bivalve shells, foraminifers (Protopeneroplis striata Weynschenk, Quinqueloculina sp., Nautiloculina oolithica Mohler (Pl. 7, Fig. 5), Trocholina alpina (Leupold) (Pl. 7, Fig. 6), algae (Thaumatoporella parvovesiculifera (Raineri), Salpingoporella fragments), lumps (Pl. 8, Fig. 3), and peloids and intraclasts of peloidal and bioclastic packstone (Pl. 8, Figs. 1, 2). The grains are cemented by a thick rim of bladed syntaxial calcite crystals which also appear within gastropod and bivalve shells and which indicate development of a moldic porosity. Dolomitization is strong (Pl. 11, Fig. 4) with individual dolomite rhombs displacing all components, especially the micritic intraclasts and micritized ooids. Dolomitization is late, because dolomite crystals which grew near particle boundaries were stopped by the rigid and insoluble rim cements. As in the previous facies, the remaining pore space is not filled. Open porosity is about $10-20 \%$.

\section{Laminated Dolomite Facies (Cores 65, 66, and 67)}

\section{Microfacies}

Thinly laminated dolomicrosparite is composed of mm-thick bands of dense dolosparite interlayered with peloidal laminae. In sparry layers pyrite crystals are common. Occasionally lamination is disturbed by the deposition of coarser sedimentary particles sinking into the soft bottom. The origin of those particles is uncertain because of the strong dolomitization (Pl. 12, Fig.1).

The laminated dolomites can originate in upper subtidal to intertidal mud flats or supratidal shabkas (Wal- ter, 1976; Purser, 1980). Three layers of laminated and structureless dolomites were recognized. Considering the poor recovery, the dolomitic intervals may be much thicker than found in the cores. The dolomites at Site 545 are interlayered with rudstones containing very coarse fragments of corals, echinoderms, bivalves, and intraclasts. Most of the biogenic particles are coated by micrite. Sessile organisms such as encrusting foraminifers, serpulids, and algae are common. This composition suggests proximity of a reef.

Echinoderm Peloidal Facies Mixed with Near-reef Detrital Facies (Sections 545-67-3 through 545-69-3)

Near-reef clastics are similar to the rudstones above and alternate with micritic echinoderm wackestones and packstones.

\section{Microfacies}

Wackestone and packstones consisting of echinoderm remains, coral fragments, serpulids, and shell debris in micritic and pelmicritic matrix. The enchinoderms are syntaxially overgrown. Dolomitization is weak.

\section{Mixed Carbonate Sandy Lithofacies (Section 545-69-3 through Core 74)}

The shallow-water carbonates earlier considered to have been deposited in a reef and lagoonal environment are underlain by carbonates of varying terrigenous influx. The lithologies are sandy limestones to calcareous sandstones (Pl. 12, Fig. 2).

\section{Microfacies}

Wackestones and packstones containing 3 to $60 \%$ of angular to subrounded quartz grains, up to $2 \mathrm{~mm}$ in diameter, feldspars, phyllitic rock fragments, echinoderm remains, gastropods, lituolid foraminifers (Ammobaculites type, Pl. 8, Fig. 6), Lenticulina, and shallow-water ooids which are partly overgrown by sessile foraminifers (Pl. 8, Fig. 5). Pieces of pyritized wood are also present. Pelagic biota is represented by ammonites, shells of pelagic bivalves, and radiolarians. Matrix of the rock is variably recrystallized pelmicrite. Three microfacies types are distinguished:

1. Sandy echinoderm peloidal facies, which is the dominant microfacies type (Cores 69, 70, 72, and 73).

2. Sandy oolitic facies represented by packstone layers in the sandy echinoderm peloidal facies (Cores 70, 71, and 72 ).

3. Sandy oolitic pelmicrite facies (Cores 73 through 75).

\section{Sedimentary History}

The Jurassic limestone sequence of Site 545 (Fig. 6) can be compared to the evolutionary stages of carbonate platforms (Jansa, 1981). The basal sandy unit represents an initial ramp stage where terrigenous components are mixed with oolites. The exact thickness of the sandy limestone deposits is unknown. They probably correspond to the Middle Jurassic regressive phase recognized in Hole 547B and onshore Morocco (Jansa and Wiedmann, 1982). The stromatolites alternating with near-reef detri- 


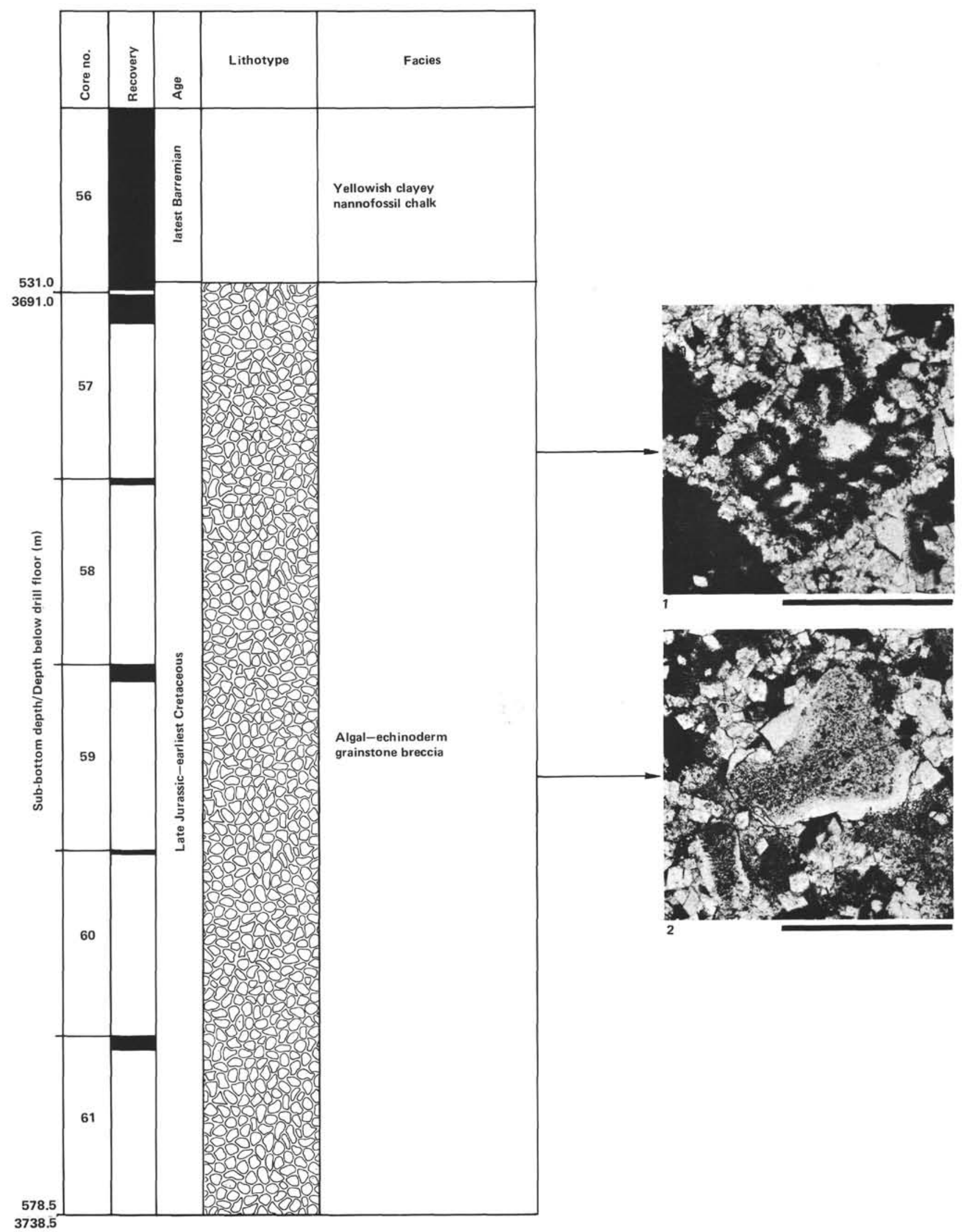

Figure 5. Lithologic column of Site 545, Jurassic carbonate platform. Photomicrographs (scale bar, $1 \mathrm{~mm}$ ): (1) Salpingoporella pygmaea Gümbel in dolomite matrix; (2) dolomitized bioclastic grainstone with calcite-ovegrown echinoderm fragments; (3) brecciated bioclastic grainstone; (4) oolitic grainstone; (5) near-reef rudstone; (6) echinoderm wackestone; (7) sandy peloid wackestone; (8) oolitic quartz packstone; (9) sandy peloid wackestone; (10) oolitic peloid wackestone. 


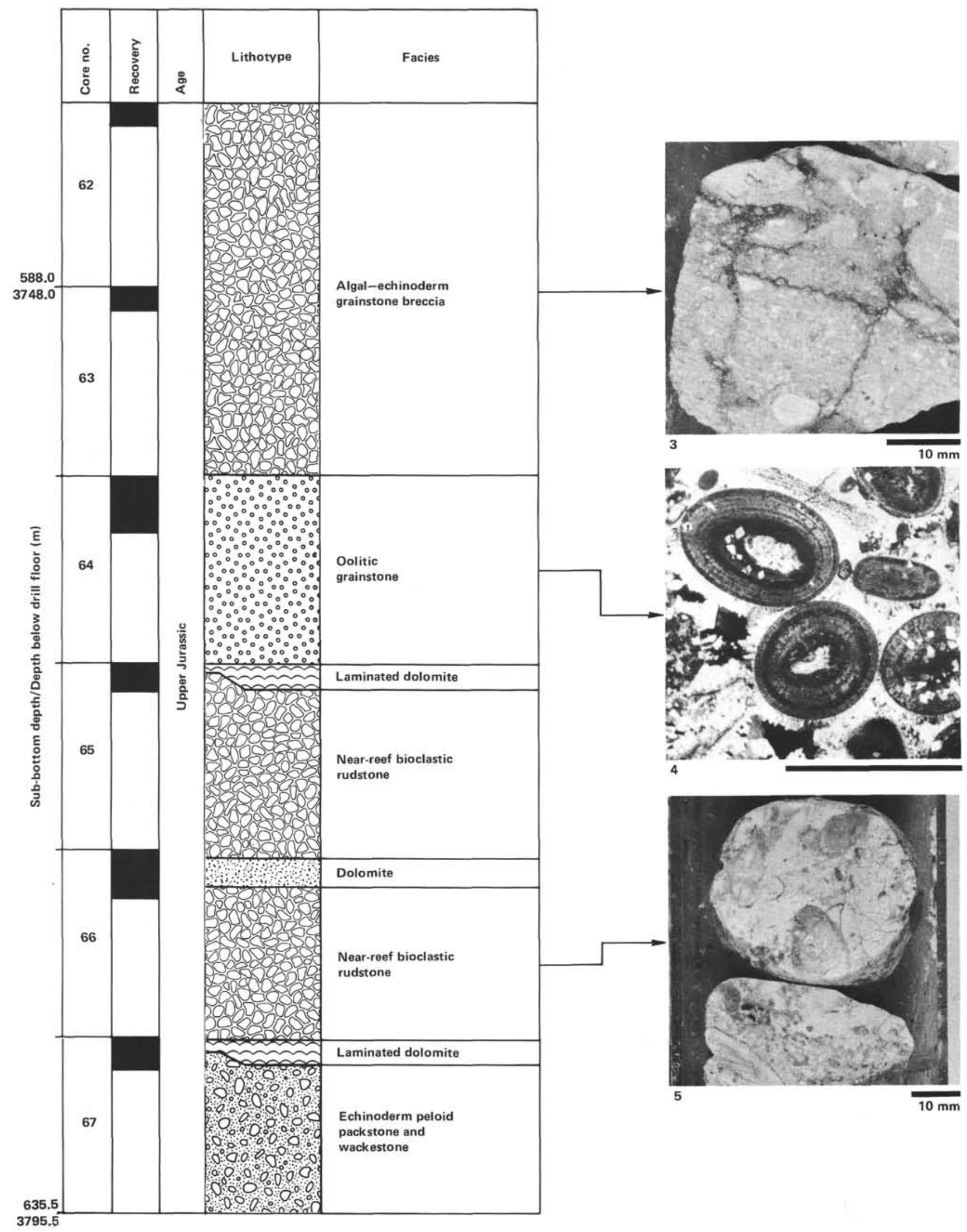

Figure 5. (Continued). 


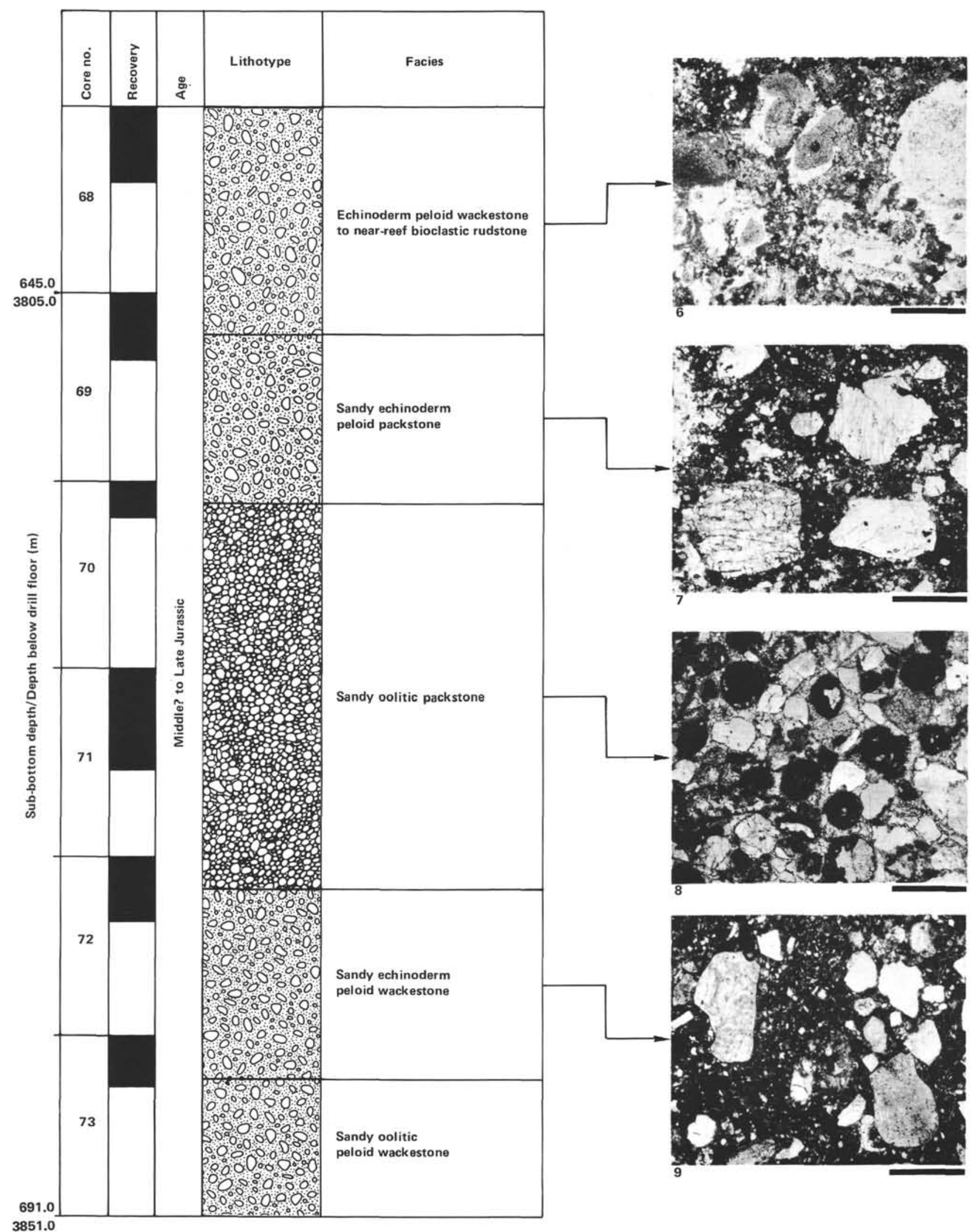

3851.0

Figure 5. (Continued). 

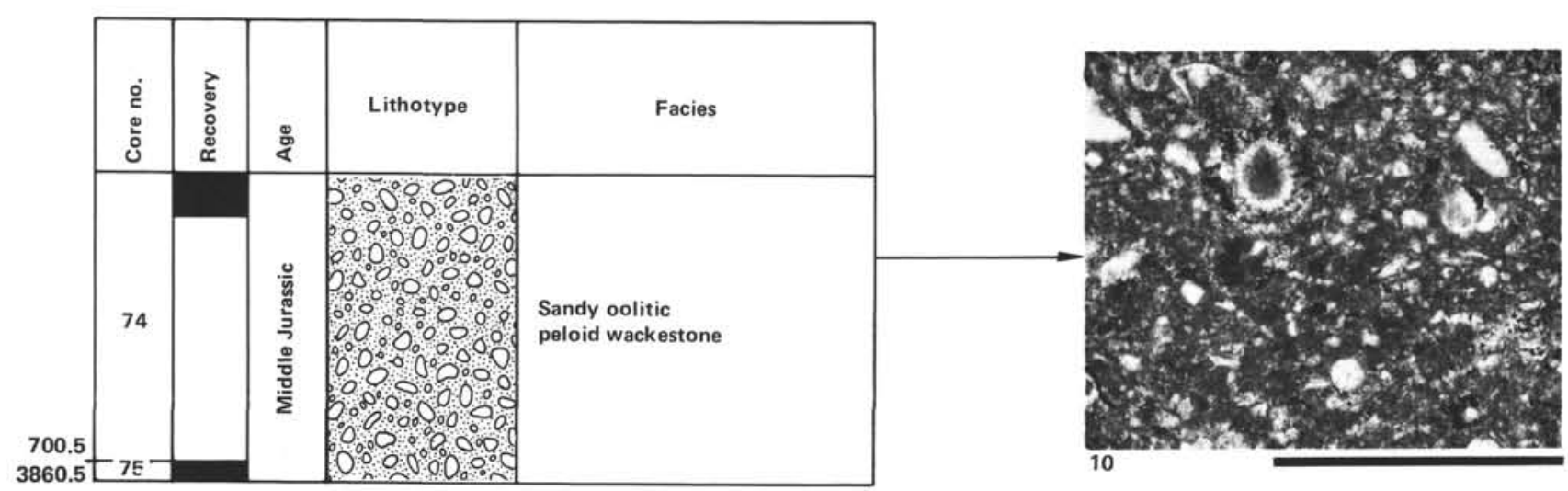

Figure 5. (Continued).

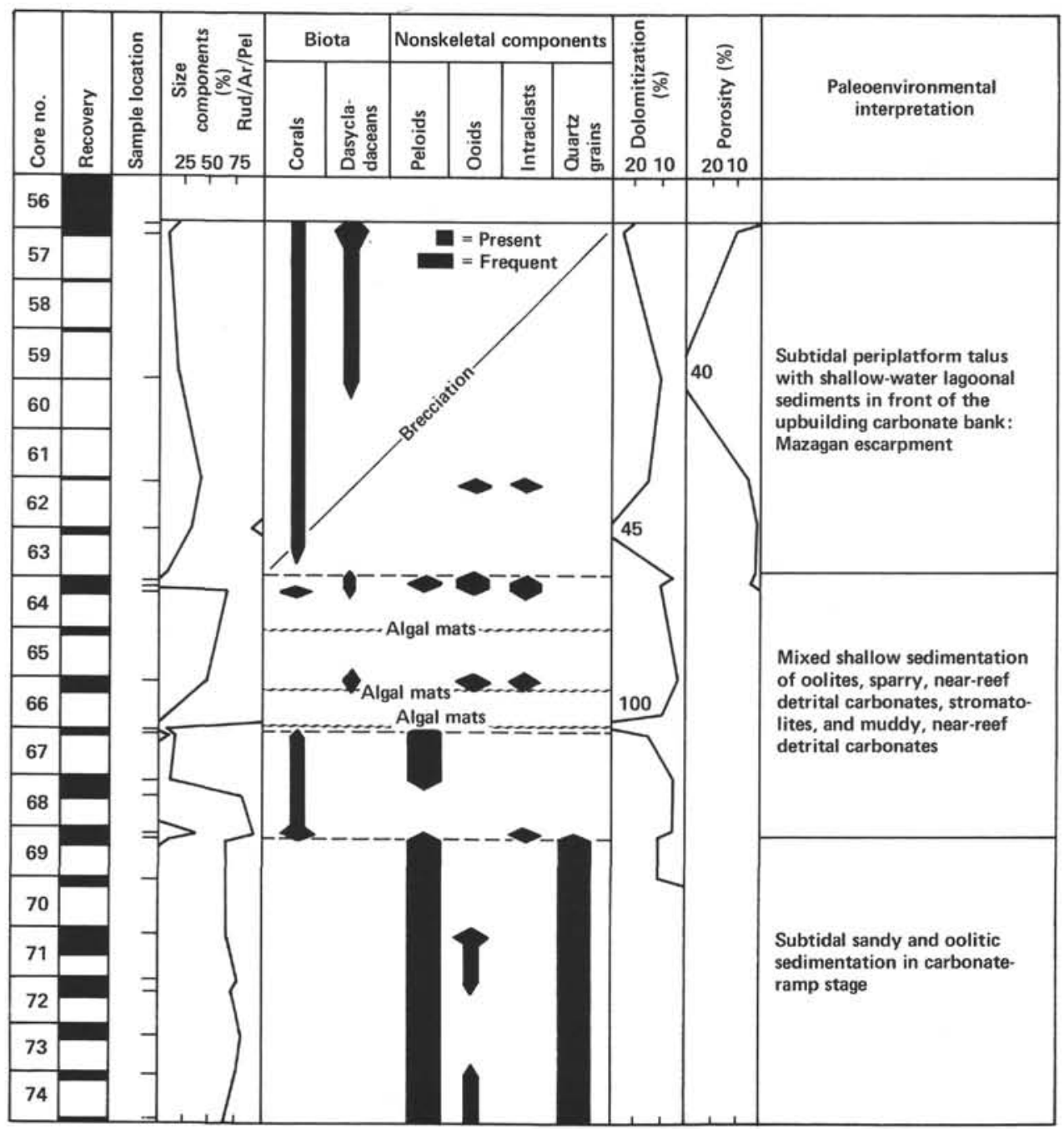

Figure 6. The sedimentological and diagenetic characteristics of Site 545 Jurassic limestones and their paleoenvironmental interpretation.

tal sediments and oolites occuring above the sandy deposits developed either as a result of mixing near the outer shelf or in response to the shallowing of the sedimentary environment. The presence of the overlying lagoonal limestones may support the latter hypothesis. In- tense brecciation, variable textural composition, and borings in some of the limestone fragments indicate the existence of an uncemented periplatform talus in front of the Mazagan Escarpment. Accumulation of the limestone clasts might be the result of platform defacing; al- 
ternatively, the clasts were brought from the inner platform by currents and then deposited on the upper platform slope.

\section{SITE 546}

At Site 546 two subrounded pebbles of Jurassic limestone were recovered (Core 16). Both clasts show similar microfabric (Fig. 7).

\section{Microfacies}

Grainstone composed of echinoderm remains with syntaxial overgrowth, superficial ooids, normal ooids, miliolid vagile benthic foraminifers, ostracodes, peloids, and rare quartz grains. Matrix is irregularly crystallized sparry calcite. No age-significant microfossils were found to date the limestone clasts. Nevertheless the observed lithologies are identical to the Upper Jurassic to lowermost Cretaceous pelsparites which crop out on the steep Mazagan Escarpment slope (CYANA dives; see Auzende et al., this volume). The limestone pebbles are embedded in Miocene nannofossil ooze and were emplaced by gravity flows. In contrast to the proximal Site 545 , the Jurassic clasts in Site 546 represent the distal end of a flow. This suggests that the elevation formed by the salt diapir postdates the gravity flows and is thus younger than middle Miocene.

\section{HOLE 547B}

The Jurassic limestone sequence of Hole 547B is dominated by basinal deposits. In the upper part, autochthonous pelagic calcisiltites alternate with coarse, resedimented deposits derived from both platform and basinal areas. The lower part of the sequence displays deposition and reworking of calcareous nodular sediments interlayered with a few thin, black shales. Brecciated and in situ stromatolites at the base of the sequence mark the marine ingression and the beginning of the calcareous sedimentation. The carbonates of Hole 547B are subdivided from top to base into five lithologic subunits (Fig. 8). Subunits A, B, and C are equivalent to Subunit VIA and Subunits D and E to Subunit VIB (see site chapter).

A. Pelagic calcisiltites with shallow-water platform turbidites, $15 \mathrm{~m}$ thick (547B-6-1, $84 \mathrm{~cm}$ to $547 \mathrm{~B}-8-3,145 \mathrm{~cm}$ ).

B. Deeper-water platform breccias and hardground cycles, $29 \mathrm{~m}$ thick (547B-8-3, $145 \mathrm{~cm}$ to $547 \mathrm{~B}-11-4,108$ $\mathrm{cm})$.

C. Sandy limestone breccias, $24 \mathrm{~m}$ thick (547B-11-4, $108 \mathrm{~cm}$ to $547 \mathrm{~B}-14-2,37 \mathrm{~cm}$ ).

D. Pelagic nodular limestones and black shales, $78 \mathrm{~m}$ thick (547B-14-2, $37 \mathrm{~cm}$ to $547 \mathrm{~B}-23-2,40 \mathrm{~cm}$ ).

E. Stromatolitic limestones, $8 \mathrm{~m}$ thick (547B-23-2, 40 $\mathrm{cm}$ to $547 \mathrm{~B}-24-1,70 \mathrm{~cm}$ ).

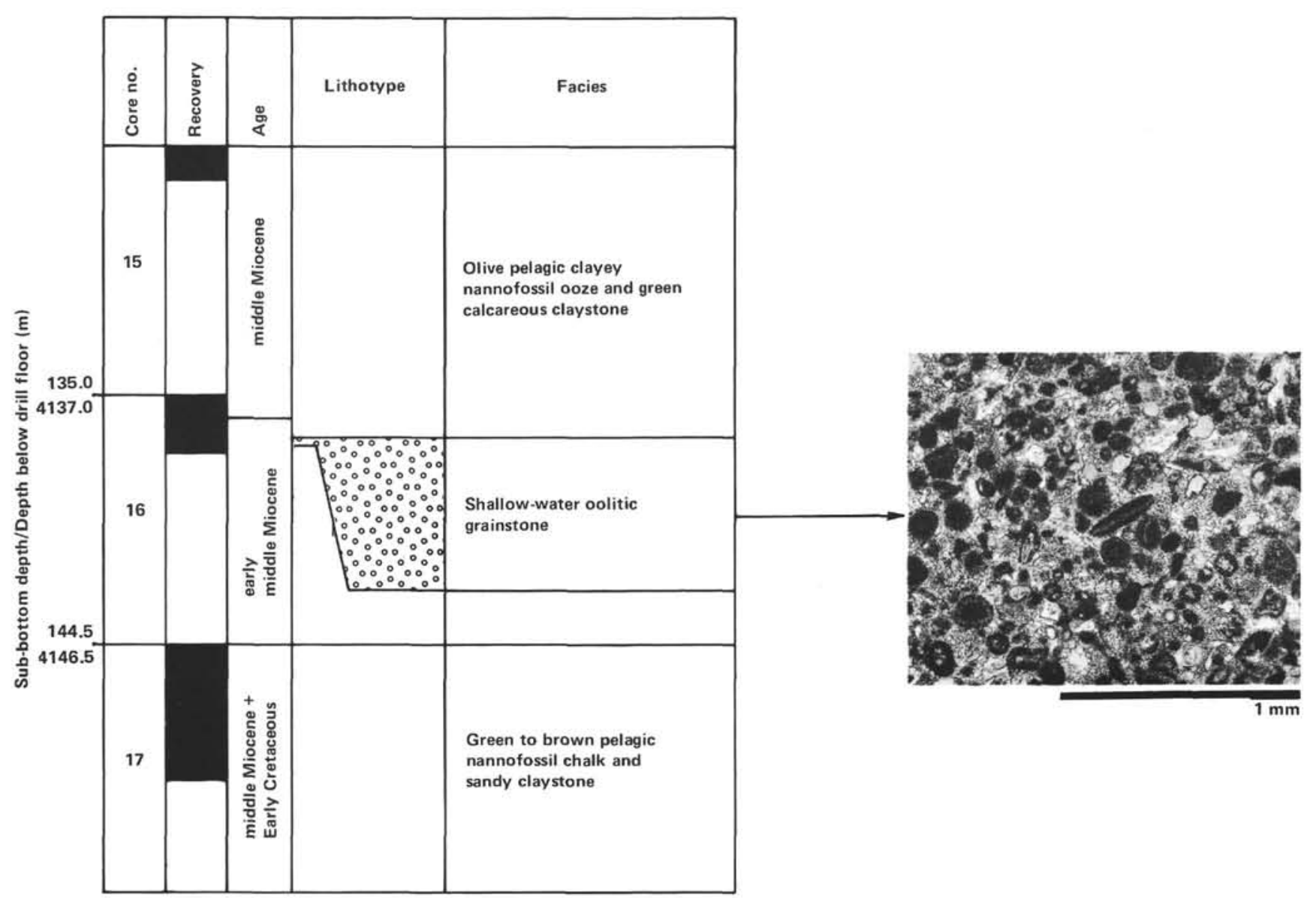

Figure 7. Lithologic column of Site 546, a salt dome on the west Mazagan Plateau containing Jurassic pebbles in middle Miocene sediments. 


\section{Subunit A. Pelagic Calcisiltites}

Four microfacies can be discerned in this subunit.

\section{Microfacies 1}

Wackestones composed of ammonities, echinoderm remains (Saccocoma, Pl. 9, Fig. 2), aptychi, textulariid and nodosariid foraminifers, Protoglobigerina sp. (Pl. 9, Fig. 3), ostracodes, calcite-filled radiolarian molds, and calpionellids (PI. 9, Fig. 1). Matrix is slightly recrystallized micrite and/or pelmicrite. The churned texture indicates bioturbation. Because calpionellids occur frequently in the uppermost $5 \mathrm{~m}$ of Subunit $\mathrm{A}$, this part of the pelagic sequence is described as the "calpionellid microfacies."

\section{Microfacies 2}

This microfacies is underlain by $8 \mathrm{~m}$ of "Saccocoma microfacies," characterized by the presence of pelagic crinoids of the Saccocoma type.

\section{Microfacies 3}

Within the autochthonous calpionellid microfacies, as well as the Saccocoma microfacies, layers of lithoclastic gravity flows, 50 to $60 \mathrm{~cm}$ thick, occur. This microfacies consists of Floatstone, rud-, and grainstones containing angular to well-rounded calcareous lithoclasts, echinoderm remains, nodosariid foraminifers, aptychi, cyanobacterial oncoids, and a very few shallowwater components such as ooids and coral fragments. The lithoclasts are mostly derived from pelagic sediments, as is indicated by the presence of wackestones with pelagic bivalves, radiolarian-sponge spicule wackestone, peloid foraminiferal wackestone, Saccocoma wackestone, and pelsparite. In the uppermost layers, calpionellid wackestone is reworked. Some of the lithoclasts resemble concretionary carbonate nodules. The lithoclasts and bioclasts are surrounded by fine-grained to recrystallized matrix. However, zones at the base and top of the coarse interlayers are cemented with sparry calcite. Geopetal infill of mainly sheltered cavities between the limestone fragments by internal sediment is common. The intraclasts intervals described are considered to represent gravity flows from the carbonate platform slope.

\section{Microfacies 4: Periplatform Turbidites (within Subunit A, Core 547B-7)}

At deeper levels in Core 547B-7, the gravity flows contain progressively more shallow-water platform material. Rudstones and grainstones (Pl. 12, Fig. 3) are composed of angular to rounded lithoclasts, echinoderm remains (coated and uncoated), molluscan shell debris, foraminifers (Pseudocyclammina lituus Yokoyama, Trocholina sp., Nautiloculina oolithica Mohler, Conicospirillina basiliensis Mohler, Protopeneroplis striata Weynschenk (Pl. 9, Fig. 6)), algae (Thaumatoporella parvovesiculifera (Raineri)), and ooids (Pl. 9, Fig. 5). Lithoclasts comprise oolitic pelsparites, foraminiferal grainstones, and bioclastic lagoonal wackestones. Some layers show higher amounts of deeper-water platform components such as cyanobacterial oncoids and pelagic bivalves. The interparticle pores are either filled with recrystallized micrite and echinoderm syntaxial calcite or contain irregularly developed calcite spar. Rims of bladed cement are occasionally observed. The turbidite beds are about 10 to 20 $\mathrm{cm}$ thick. In contrast to the pelagic-slope gravity flows, the periplatform turbidites show grain-size grading.

\section{Subunit B. Deeper-Water Platform Breccias and Hardground Cycles}

The petrographic composition of Subunit B indicates the youngest depositional influence of the Mazagan carbonate platform at Site 547 during the Oxfordian. At this time the platform margin approached the Site 547 basin. Nodular limestones, coquinas of pelagic bivalves, redeposited proximal deeper-water platform sediments, hardground cycles, and in place carbonate crusts reflect fluctuation of the platform boundary.

\section{B1. Nodular Limestones and Layers with Pelagic Bivalves}

The pelagic calcisiltites and calcareous turbidites of Subunit A are underlain by a sequence of grayish or greenish nodular limestones in which three layers of pelagic bivalves occur.

\section{Microfacies 1. Nodular Limestones}

Wackestones composed of calcareous nodules which contain juvenile ammonites, pelagic bivalves, small gastropods, brachiopods, nodosariid foraminifers, and radiolarians. The nodules float in recrystallized micrite matrix. Sand-sized angular quartz grains are rare and scattered in the matrix. Clay seams around the calcareous nodules suggest pressure solution during compaction.

\section{Microfacies 2. Coquina}

Packstones composed of elongated shells of pelagic bivalves up to $15 \mathrm{~mm}$ in length over an area of up to $60 \%$ of the slide studied. Pelmicritic intraclasts, Protoglobigerina sp., echinoderm remains, ostracodes, and sponge spicules are present. Matrix is recrystallized micrite. The shells of the pelagic bivalves generated primary shelter and umbrella porosity. The voids are floored with internal sediment, with the remaining porosity occluded by sparry calcite. In contact with the micritic matrix, the bivalve shells are syntaxially rimmed by neomorphic calcite. Cubes of pyrite which replace micritic and sparitic carbonate are common.

\section{B2. Proximal Limestone Breccias}

The lowest coquina found in Core 8 caps an interval of coarse, calcareous breccias $11 \mathrm{~m}$ thick.

\section{Microfacies}

Rudstones and floatstones composed of angular to rounded limestone lithoclasts, cyanobacterial oncoids, lumps, calcareous nodules, ammonite shells, encrusted fragments of gastropods and bivalves, echinoderm remains, foraminifers (Lenticulina, Nodosaria, Ophthalmidium, sessile foraminifers [PI. 10, Fig. 1]), ostracodes, brachiopods, and calcitized siliceous sponges. Litho- 


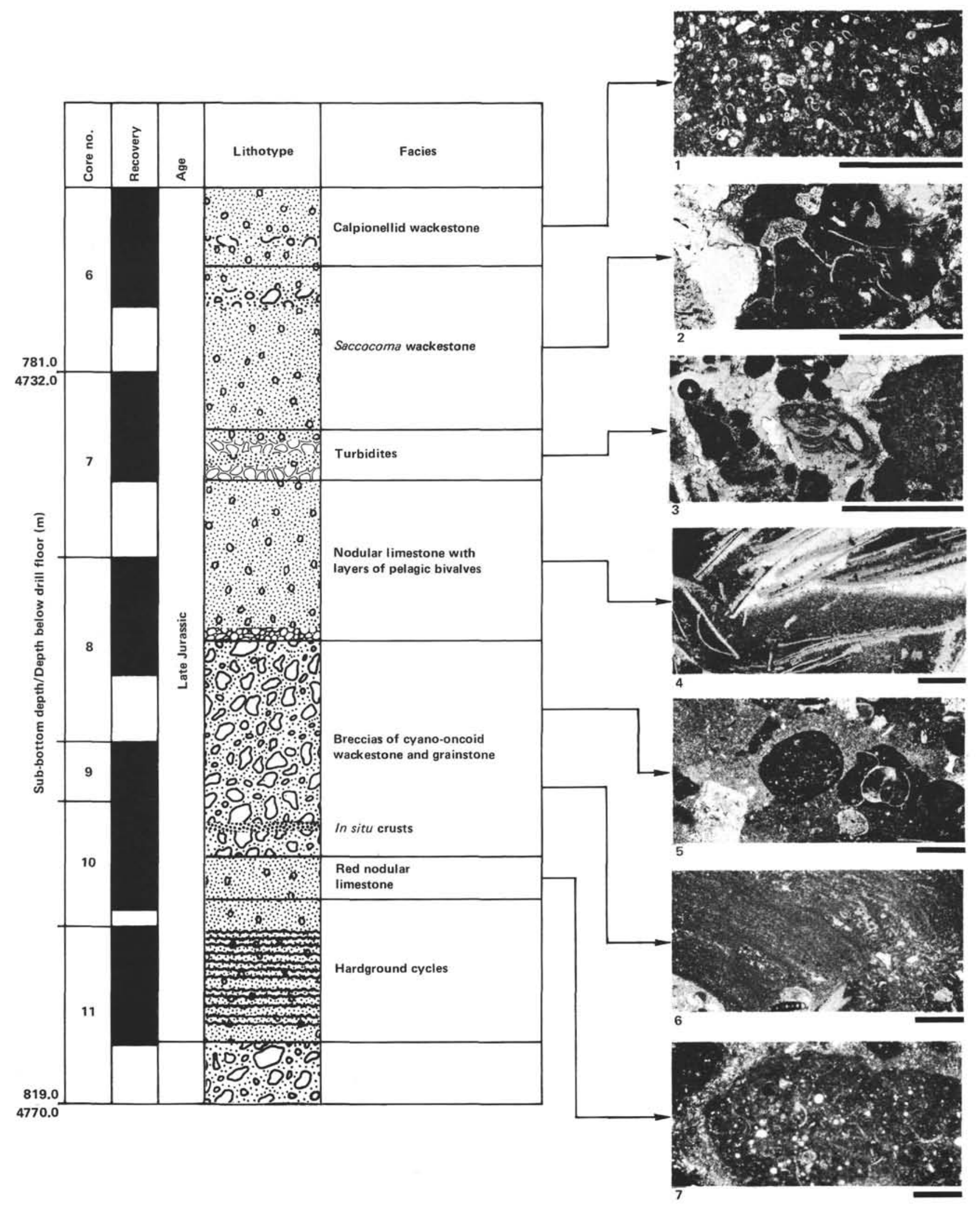

Figure 8. Lithologic column of Hole 547B, Mazagan Plateau. Main facies types of the Jurassic limestones. Photomicrographs (scale bar, 1 mm): (1) calpionellid wackestone; (2) turbidite with Saccocoma wackestone clast; (3) turbidite with Conicospirillina basiliensis Mohler; (4) coquina with pelagic bivalves; (5) cyano-oncoid wackestone; (6) pelmicritic crust; (7) carbonate nodule composed of radiolarians and ostracodes; (8) lithoclastic floatstone; (9) nodular wackestone; (10) dense nodular wackestone; (11) intraclastic packstone; (12) domal fenestral bindstone; (13) laminated bindstone. 


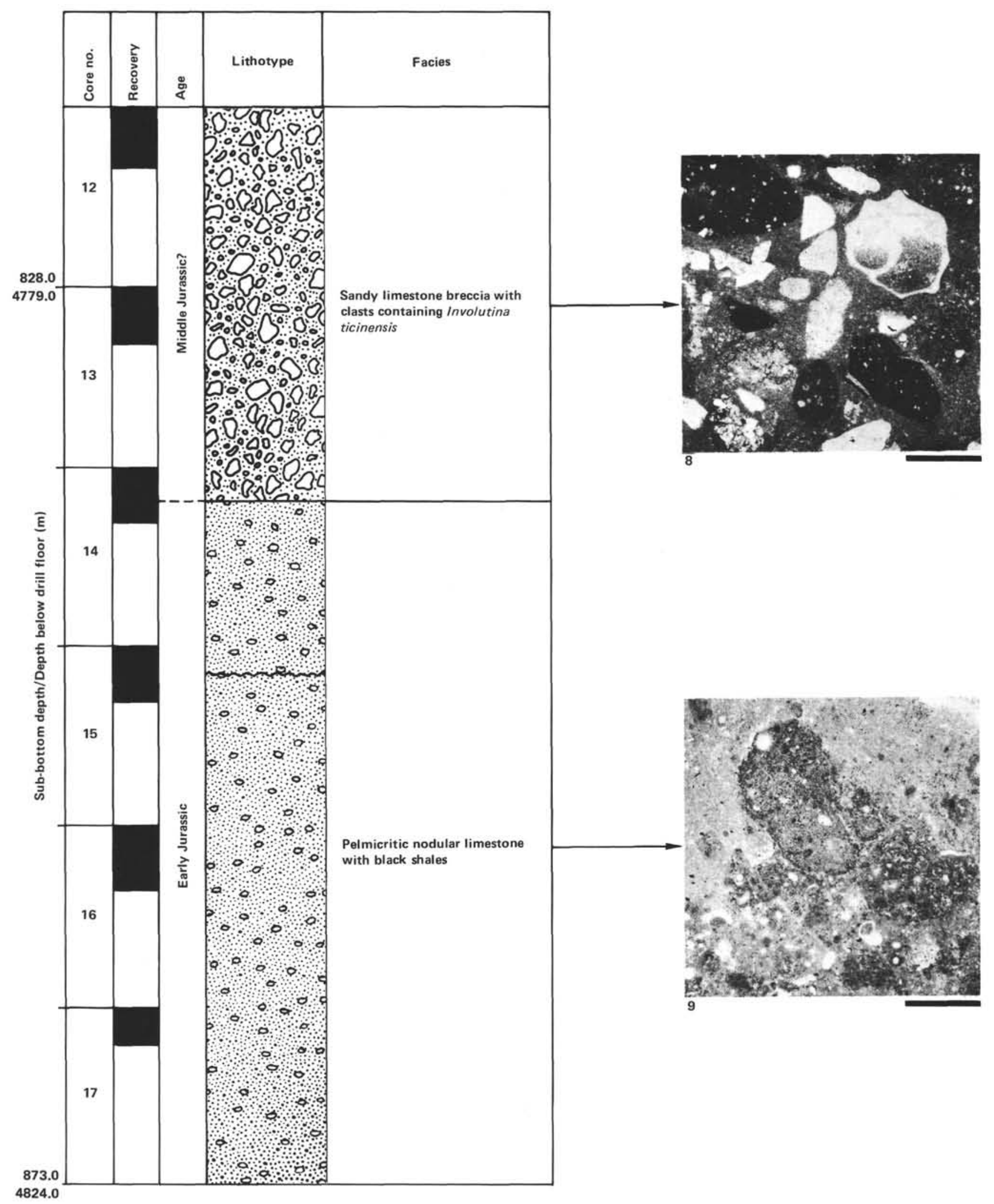

Figure 8. (Continued). 


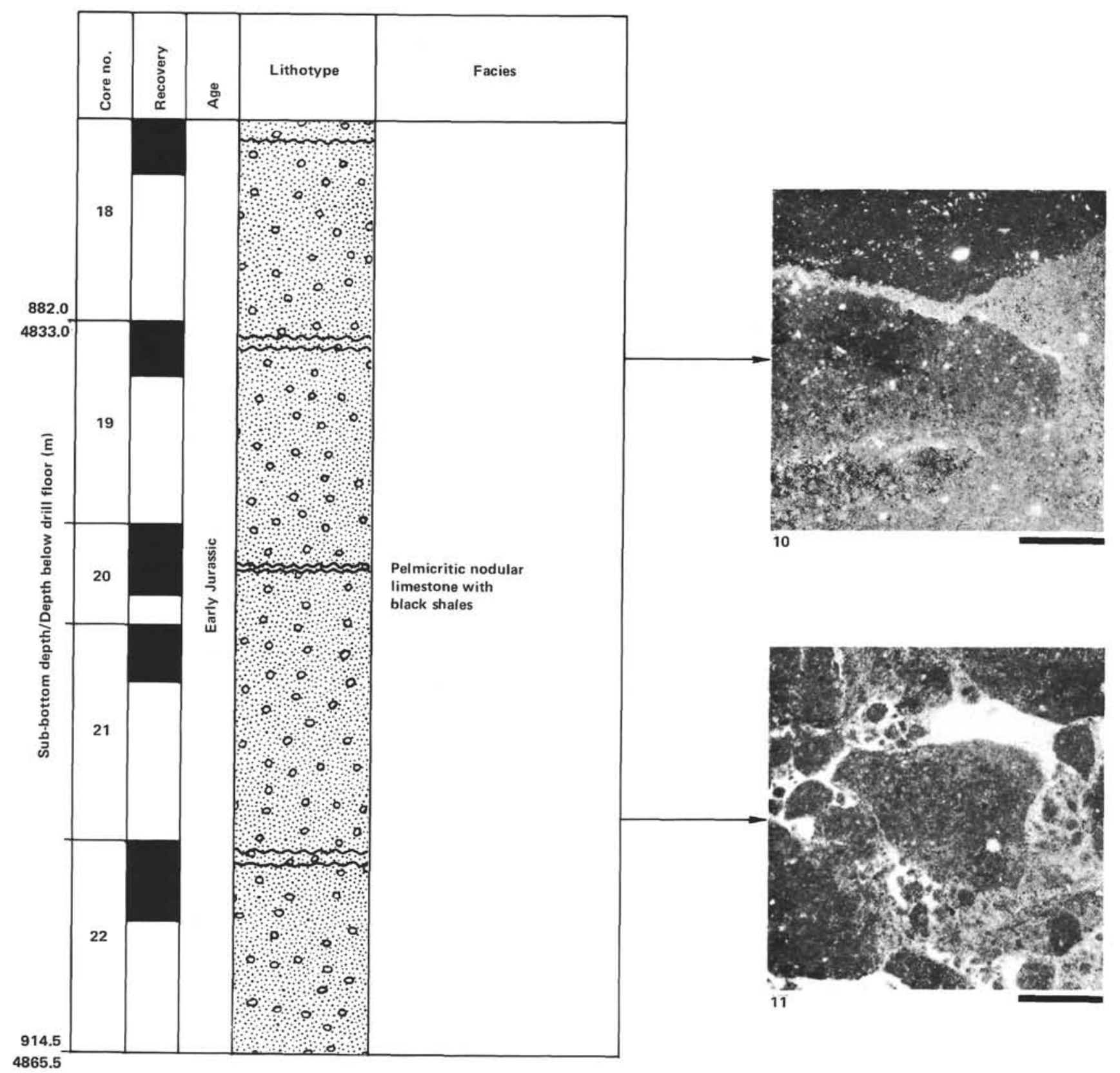

Figure 8. (Continued).

clasts comprise echinoderm foraminiferal wackestones, oncolitic foraminiferal grainstones, radiolarian wackestones, echinoderm sponge spicule wackestones, cyanooncoid packstones (Pl. 10, Fig. 2), pelagic bivalve foraminiferal packstones, and pelmicritic crusts. The breccias have grain-supported texture. Interparticle pores are geopetally filled by highly recrystallized micrite. The sparry cement in some of the voids is contemporaneous with the internal sedimentation.

Sorting of the breccia components is poor. Grain sizes vary from sand-sized to a maximum diameter of $15 \mathrm{~cm}$. The source of the clasts is the cyano-oncoid peloidal crust-siliceous sponge environment located on the seaward margin of the outer platform.
The sequence of breccias is interrupted by two in situ deposits. In the uppermost part of the breccia unit limestones composed mainly of skeletal particles rather than lithoclasts are intercalated. The composition is identical with the cyanobacterial oncoid facies found at Site 544 (PI. 12, Fig. 4). The other in situ deposit consists of peloidal crusts seen in the lower part of the breccia unit (PI. 13, Fig. 1).

The breccias are underlain by $2 \mathrm{~m}$ of red nodular limestones.

\section{B3. Hardground Cycles}

This interval is composed of 12 cycles of pelagic wackestones alternating with breccias consisting of in- 

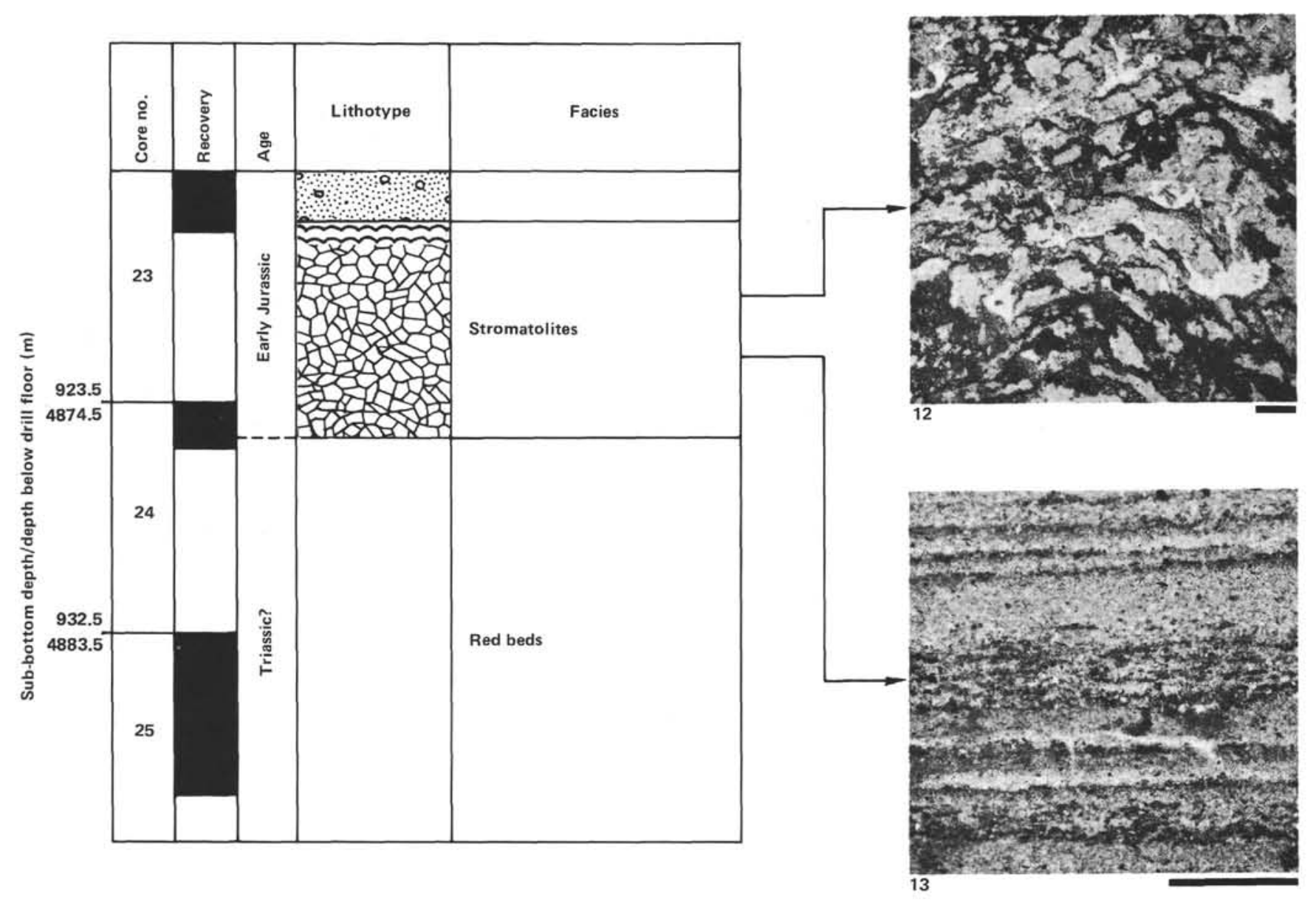

Figure 8. (Continued).

traclasts of similar pelagic wackestone. The pelagic wackestone layers are terminated by sharp surfaces at the base and top (Fig. 9). Presence of sessile foraminifers suggest early lithification of the muddy substrate.

\section{Microfacies 1. Pelagic Wackestone Layers}

Wackestones containing ammonites, sponge spicules, ostracodes, radiolarians, gastropods, and cyanobacterial oncoids in micritic matrix. The sediment is highly bioturbated.

\section{Microfacies 2. Breccias}

Rudstones and grainstones composed of angular to well-rounded lithoclasts of pelagic wackestone. Other components are Tubiphytes sp., echinoderm remains, molluscan shell debris, foraminiferal oncoids, and angular quartz grains. According to grain size and composition, two different types of breccias occur together in the layers (Figs. 9 and 10). The first type is a breccia with poorly sorted pebble- and cobble-sized, angular clasts of monomictic composition. The clasts consist of a wackestone which contains radiolarians, sponge spicules, ostracodes, and ammonites. The second breccia type is polymictic, with well-sorted clasts which are sand-sized and well-rounded. These components are found as internal sediment in pockets and on ledges formed by the irregularly shaped wackestone clasts of the first breccia type.
Not only the bimodal composition of the breccias, but also numerous infiltration phases of silt-sized internal sediments indicate a very complex depositional history for the breccia layers. Individual laminae of internal sediment are separated by breaks in grain size and by thick rims of clear cement. Phenomena unusual for normal breccias of redeposited sediment are:

a. Presence of elongated caverns at the contacts between the pelagic wackestone and the breccias. In vertical section the pelagic wackestone sediment first appears in the open spaces of the underlying pores of the breccia indicating that the caverns predate the deposition of the pelagic wackestone.

b. Internal sediments are occasionally "attached" to the roofs of the caverns. Normally, silt-sized internal deposits floor the open cavities. But "inverse geopetal fabric" is also developed. Both normal geopetal fabric and sediment found in the tops of the pores are present in the same core sections (Fig. 10).

Our explanation of the evolution of the bimodal breccias is given in Figure 11. A first stage comprises the deposition of a pelagic wackestone bed 20 to $50 \mathrm{~cm}$ thick. The sediment is soft and lies upon a previous wackestone layer, which has already been lithified. The new sediment is subsequently burrowed throughout the total thickness.

After deposition, lithification starts a few $\mathrm{cm}$ below the seafloor (Fũrsich, 1979) prograding downward and upward. Bottom currents are strong enough to erode the 


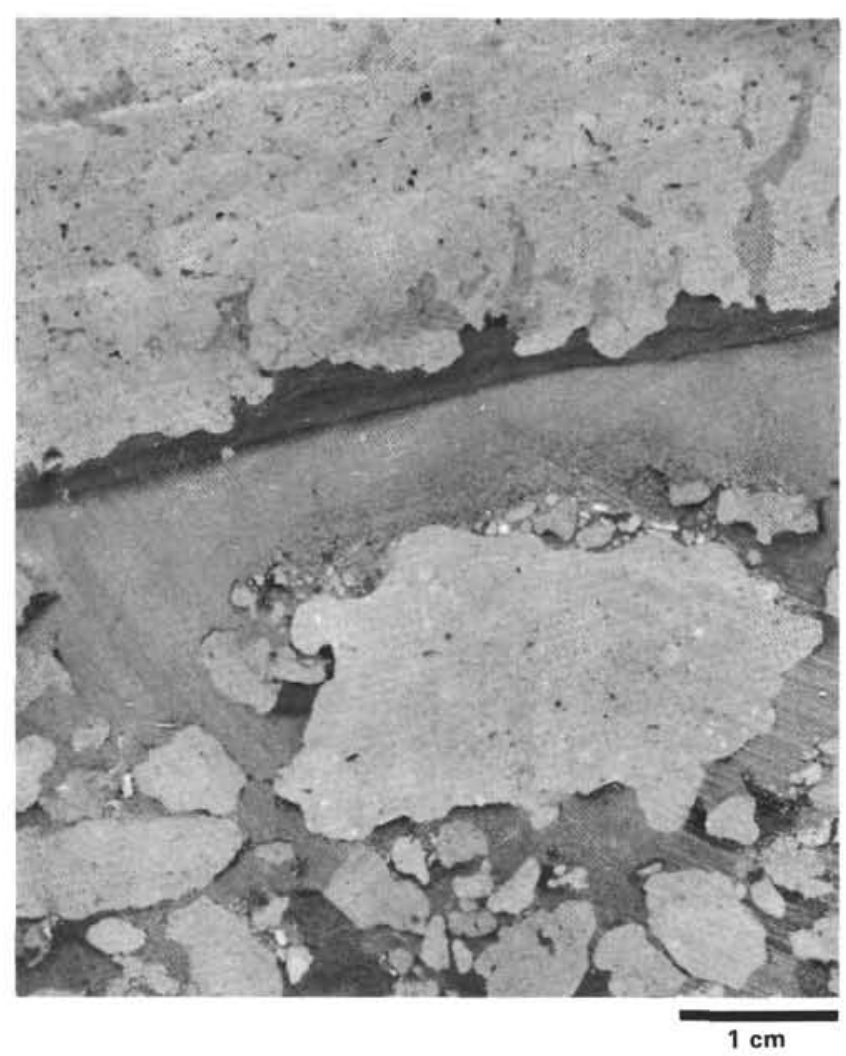

Figure 9. Deeper-slope hardgrounds. Highly bioturbated pelagic wackestone covers a partly collapsed porous wackestone framework. The interparticle pores are occluded by fine-grained internal sediment. Ledges of stable wackestone are covered by sand-sized sediment. Permeability is finally reduced to the uppermost pores, where numerous layers of internal sediment are visible. Sample 547B-11-3, $33-39.5 \mathrm{~cm}$.

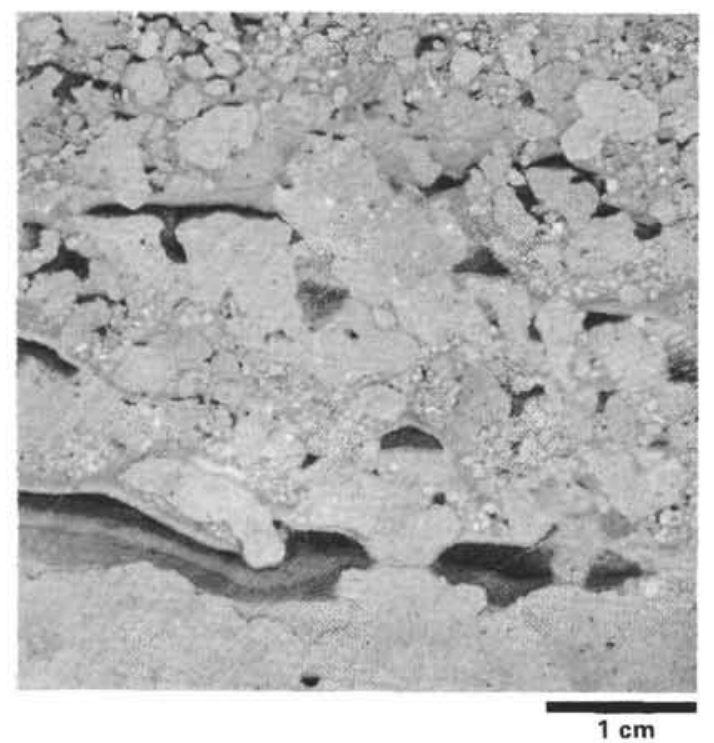

Figure 10. Breccia in deeper-slope hardground cycle. The elongated cavern in the contact between the underlying intact wackestone layer and the breccia not only shows geopetal fabric, but also micritic sediment "hanging from the roof." This is also visible in the upper left. "Inverse geopetal fabric" may be generated by selective displacement of chemically and mechanically eroding interparticle currents. Sample 547B-11-1, 108-113 cm. firm ground and form a sharp upper surface. Interparticle currents wash out soft material from the interior of the wackestone bed. The soft material is patchily distributed within a framework of semilithified rock. The irregular and patchy distribution of firm and soft material is possibly caused by the intense bioturbation (compare Kennedy and Garrison, 1975).

While interparticle currents remove soft original sediment, a multiple-phase internal sedimentation begins. In response to strong erosion and loading, the lithified porous wackestone framework partly collapses, forming in situ breccias. Some of the fragments are reworked, well rounded, reduced to sand size, and incorporated as constituents of the secondary sedimentary infill (fine-grained breccia). Most of the pores, however, are occluded by carbonate mud. Thin-section analysis confirms the sedimentary origin of the infiltrated micritic carbonate, which is composed of peloids and crystal silt. Early lithification of the internal sediments is necessary for the development of the "inverse geopetal fabric." Chemical solution or multiple phases of mechanical erosion are required for selective sediment removal. In this way, multigenerational porosities are produced. Continuous sedimentary infiltration then closes the passages in the pore systems. In the protected internal open spaces, clear cements begin to grow. After the passages are reopened (new phase of erosion) the cement rims are covered with new layers of internal sediment. When the pores remain closed, the void is filled with equant, blocky calcite crystals. The multiple-phase sedimentary infill is best seen at the top of the breccia beds.

The evolution of the wackestone/breccia cycles probably required a very long time and was associated with periods of nondeposition or very slow deposition.

\section{Subunit C. Sandy Limestone Breccias}

The hardgrounds of Subunit B3, which are increasingly interlayered with uniform micritic sediments, are underlain by very heterogenous breccias, approximately $22.5 \mathrm{~m}$ thick. Subunit $\mathrm{C}$ is divided into several individual deposits distinguished by color and structure (gray and red breccias). The individual breccia intervals range between $20 \mathrm{~cm}$ and $1 \mathrm{~m}$ thick. Whereas thin, graded conglomeratic layers strongly vary in lithologies, thick breccia beds mostly show monomictic composition.

\section{Microfacies}

Rudstones and floatstones composed of angular to well-rounded lithoclasts, echinoderm remains, gastropods, foraminifers (Lenticula, Ophthalmidium, textulariids), ammonites, and angular quartz grains. The lithoclasts are represented by rounded wackestone clasts containing calcitized siliceous sponges and radiolarians; lithoclasts of pelmicritic crusts; red sandstone; bioclastic wackestone with Involutina ticinensis (Schweighauser) (Bernoulli, pers. comm., 1982; compare Bernoulli, this volume) and sponge spicules (Pl. 13, Fig. 2); sponge spicule wackestone; sandy bioclastic wackestone with shells of pelagic bivalves, Globochaete alpina, radiolarians, and sponge spicules; clayey bioclastic wackestones with ostracodes and sponge spicules; bioclastic wackestone with quartz grains, authigenous dolomite crystals, and 

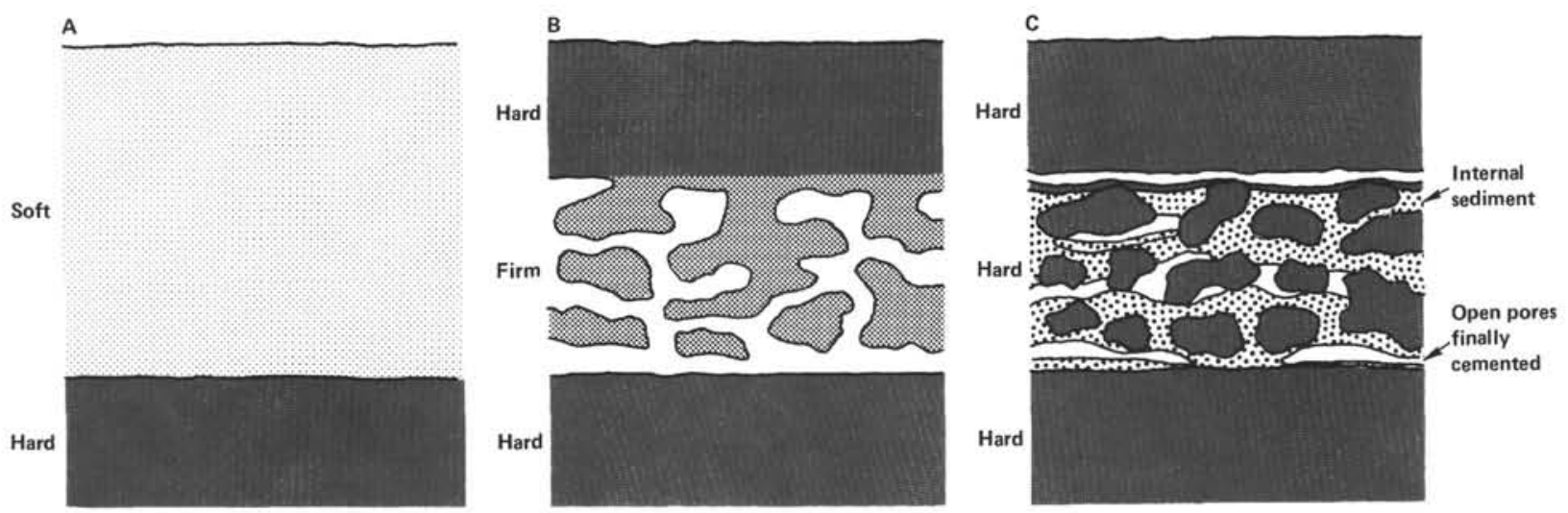

Figure 11. Evolutionary stages of deeper-slope hardgrounds observed in Hole 547B. A. Periodic sedimentation of pelagic wackestone; intense burrowing of the soft substrate. B. Subsurface lithification and erosional washout of the patchily lithified basal zone of the wackestone layer. C. Long-term and multiple infiltration and cementation in occasionally collapsing porous fabric; early lithification of internal sediment; chemical and mechanical erosion by strong interparticle currents.

ostracodes; echinoderm packstone; red clayey micrite; recrystallized stromatolite fragments and cyanobacterial oncoid wackestone. The particles are embedded in a micrite matrix (Pl. 13, Fig. 3). Occasionally grain-supported breccias show geopetal fabric. The internal sediments are thinly layered and are composed of recrystallized carbonate particles and angular quartz grains. Open pores are occluded by sparry cement. At least two generations of rim cement are present.

\section{Subunit D. Pelagic Nodular Limestones and Black Shales}

This subunit is a 77-m-thick sequence of nodular limestones with numerous intercalations of thin black shale deposits (Fig. 8) dated as Early Jurassic (site report). The nodular limestones are floatstones, packstones, and wackestones composed of micritic calcareous nodules in clayey or recrystallized micritic matrix. These rocks grade into continuous calcareous nodular "crusts" or pavements. Textural fabrics of the nodular limestone vary in response to original mineralogy (e.g., clay content; compare Zankl, 1969) and particle composition as well as sedimentary and diagenetic processes:

\section{Microfacies}

Five categories are distinguished.

1. Wackestones containing dark, round clots of micrite. These clots show indistinct contacts with the surrounding light, recrystallized sediment (Pl. 10, Fig. 4). In the dark micrite are concentrated numerous skeletons of pelagic organisms, such as radiolarians, sponge spicules, gastropods, and ostracodes.

2 . Floatstones containing clearly defined micritic nodules (Pl. 10, Fig. 3). Nodular micrite is again formed around pelagic microfossils. The nodules float in clayey or recrystallized calcareous matrix. Here, small, angular quartz grains are frequently encountered. These quartz grains can be regarded as pressure solution residues (Trurnit, 1968; Logan and Semeniuk, 1976; Wanless, 1981).

3. Packstones composed of calcareous nodules that are separated by clay seams of variable thickness inter- preted as stylocumulate residual matrix (Logan and Semeniuk, 1976). These stylonodular rocks (classification after Logan and Semeniuk, 1976) reveal very different origins: (a) in situ compaction with pressure solution and concentration of clay-rich matrix; (b) marginal solution of calcareous nodules after deposition in debris flows and turbidites.

Therefore, nodular calcareous sediments may converge in texture during diagenesis, especially in the late stages of compaction associated with pressure solution.

4. In situ nodular crusts are represented by a few intervals consisting of continuously stratified wackestones with irregular upper and lower boundaries. Above and below these layers, wackestones grade into nodular beds in which nodules decrease in density. The "wackestonecrust" are comparable to the Site 544 hardgrounds and indicate occasional lithification of the sedimentary surfaces.

5. Breccias. Angular lithoclasts of reworked wackestone hardgrounds and calcareous nodules are deposited in densely packed, polymictic breccias. The lithoclasts vary in texture and in color (gray and pale yellowish brown to grayish orange). The breccias, mostly in the lower part of Subunit D, are altered to stylobreccias by compaction and pressure solution.

The process of nodule formation is not resolved. Various theories have been proposed (Jenkyns, 1974; Tucker, 1974; Garrison and Kennedy, 1977). The three main processes are (a) reworking of hardgrounds and rolling of the angular fragments (Elmi, 1981); (b) compositional differentiation resulting from bioturbation (Mullins et al., 1980). Nodules are unburrowed sediment surrounded by compacted, clay-rich worm tubes (Eller, 1981; Elmi, 1981); (c) Concretional subsurface cementation of accumulated biogenous material (Kukal, 1975). Fossils are concentrated in worm tubes or in current ripples.

As in Hole 547B the transition from nodular limestones into black shales confirms that burrowing plays an important role in nodule development. Nodules decrease in frequency and size toward the black shales that mark the change to euxinic conditions. Burrows in the euxinic sediment are rich in pyrite (dark grey color). The 
first calcareous nodules have the same diameter as the pyrite-rich burrows in the black shales. In true nodular limestones no dark burrows are visible.

The model (Fig. 12) for the evolution of the Hole 547B nodular limestones is based upon processes of concretionary bacterial subsurface lithification with variable distributional density. In this model the particular effect of marine diagenesis on rocks that have never been affected by subaerial exposure is also considered. The phenomenon of strong pressure solution that is known from land exposures such as the Adnet limestone (Bernoulli and Jenkyns, 1970) and the Ammonitico Rosso (Garcia-Hernandez et al., 1981) did not develop in these sediments, and it is suggested that intermediate evolutionary stages of nodule formation (nodules with indistinct boundaries) are preserved.

From the studies of Hole 547B we distinguish in situ and allochthonous nodule development:

1. In situ nodules. These are formed within the sediment; in vertical profile their frequency varies from widely separated nodules to continuous, nodular crustlike pavements. The gradational boundaries are preserved even during late diagenesis, probably because the clay content is very low and the carbonate matrix was recrystallized early. But increased lithification in clay-rich matrix leads to the development of sharp boundaries. The nodules embedded in clayey matrix need more time to lithify. Well-defined nodules better resist the overburden, and subsequent compaction and pressure solution generate dense stylonodular packstones (fitted stylonodular packstones). Original nodular wackestones with matrix rich in clay are enriched by additional clay during pressure solution (stylocumulate wackestone). The unlithified matrix could be occasionally washed out, leading to the concentration of calcareous nodules. Nodular and stylonodular packstones could be formed by such processes.

2. Allochthonous nodular limestones. Reworking is frequent in the Hole 547B nodular limestones, as is indicated by brecciation and the polymictic composition of the nodules. The nodules could originate from angular lithoclasts which were formed by fragmentation of continuous crusts and of dense, irregular nodular limestones. In contrast, the small nodules of nodular wackestones were simply removed and not fractured. However, most of the reworked clasts are angular. This suggests intense erosion of nodular pavements and short-distance transport.

The model in Figure 12 includes two texture types, the result of different ways of transport. The Hole 547B reworked nodular limestones are completely ungraded and may, therefore, be deposited by various kinds of short-distance currents. Graded nodular limestones formed by turbidity currents occur in the Upper Jurassic section of Site 547B (Oxfordian periplatform turbidites).

\section{Subunit E. Stromatolitic Facies}

The lowermost $8.5 \mathrm{~m}$ of the carbonate sequence in Hole 547B consist of a stromatolitic facies. This basal subunit comformably overlies terrigenous continental red beds.

\section{Microfacies}

Two categories are distinguished.

1. Fenestral bindstone (Fig. 8). Sparry polygons are arranged parallel to the bedding, separated from each other by pelmicritic partitions. The layers are domeshaped.

2. Laminated stromatolite (Fig. 8). Bindstones composed of alternating thin peloid and microspar layers. The sediment is lalerally fragmented, and the sheet cracks are filled with stromatolite clasts. Laminated stromatolites contain calcitic pseudomorphs of undeterminable evaporitic minerals (probably gypsum, Pl. 10, Fig. 6; compare Kinsman, 1966, and Shearman, 1966).

To the base of the subunit the stromatolites become intercalated with brecciated stromatolite horizons. Here, in situ stromatolites show erosional surfaces. Only a few $\mathrm{cm}$ of this alternation was recovered. The basal part of the sequence is formed by reworked stromatolitic limestones composed mainly of pebbles consisting of laminated dolomite. The lithology indicates periodic highenergy conditions, each during a period of initial marine transgression. A low-energy, shallow-marine environment, established at the end of deposition of Subunit $\mathrm{D}$, allowed the stromatolites to be preserved. We suggest that the stromatolites flourished in a shallow subtidal environment just before a rapid change to deeper marine conditions (Section 547B-23-2 with pelagic wackestones containing Schizosphaerella; see Kälin and Bernoulli, this volume).

\section{The Sedimentary History of the Hole 547B Limestones}

Sedimentologic and geophysical data confirm the slope position of Hole 547B (Fig. 13). The constitutional changes of the limestones discussed in this chapter indicate a restricted basinal stage which is followed by an open-marine phase. A regressive depositional interval separates these two main settings. The restricted circulation during the basinal stage is demonstrated by the presence of black shales. Carbonate deposition started with a transgression, when stromatolitic sediments were deposited. A striking break between stromatolites and pelagic wackestones indicates very rapid initial subsidence. Presence of nodular limestones with pelagic fauna suggests the development of a "deeper" basinal environment during the Early Jurassic. Regressive sediments, possibly of Dogger age, are red calcareous breccias that contain clasts of pelagic calcareous slope deposits mixed with shelf sandstones. Liassic rock fragments are also encountered. Terrigenous influx is indicated by the presence of angular quartz grains. The regressive breccias seem to fill up the Liassic basin.

The development of hardgrounds above the regressive phase indicates increased activity of bottom currents and/or periodic low deposition. The relief between the Hole 547B basin and the Site 544 segment must have been low, because comparable cyanobacterial oncoid fa- 


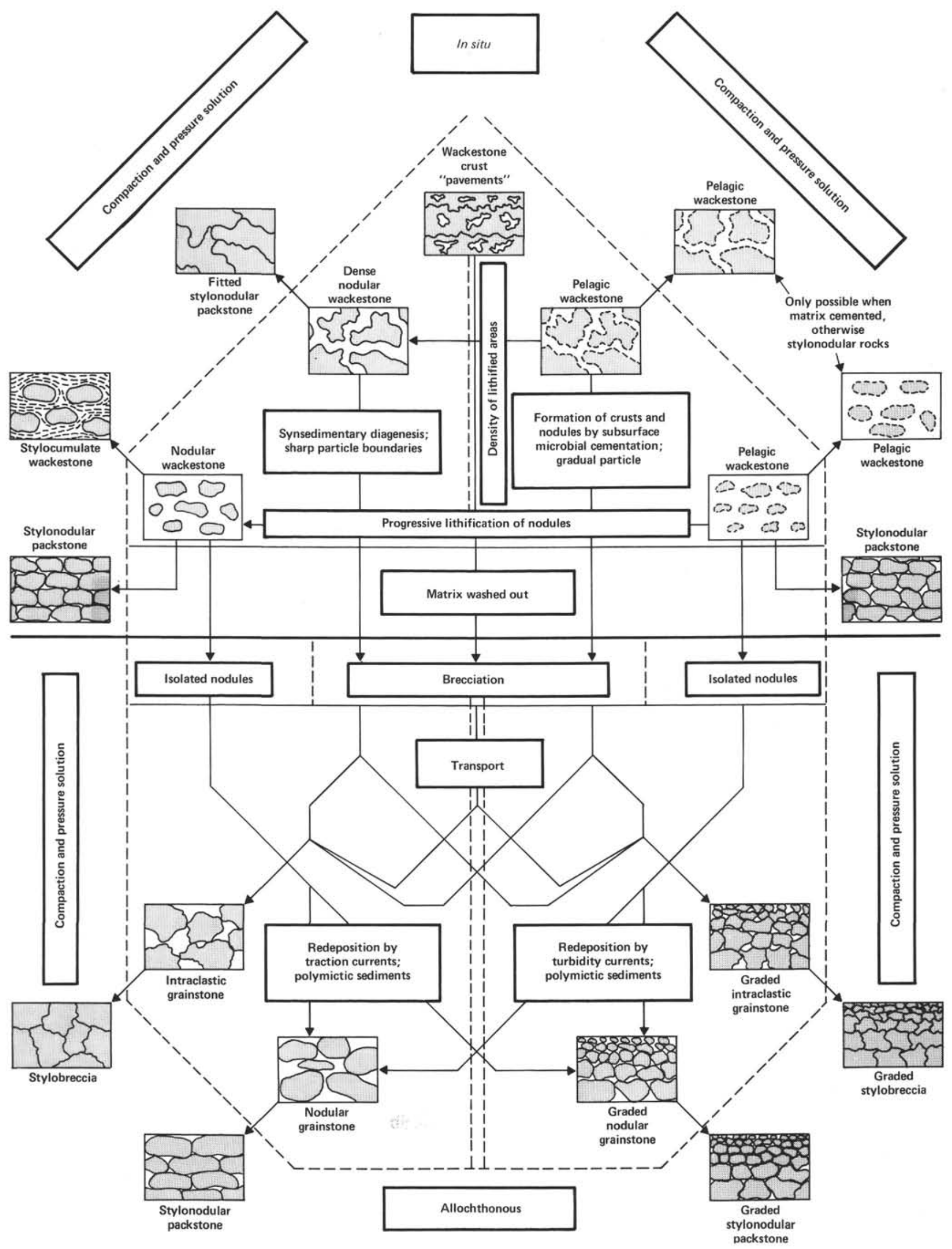

Figure 12. Scheme of nodule formation and sedimentary history of nodular limestones drawn from the microfacies types observed in Hole 547B. 


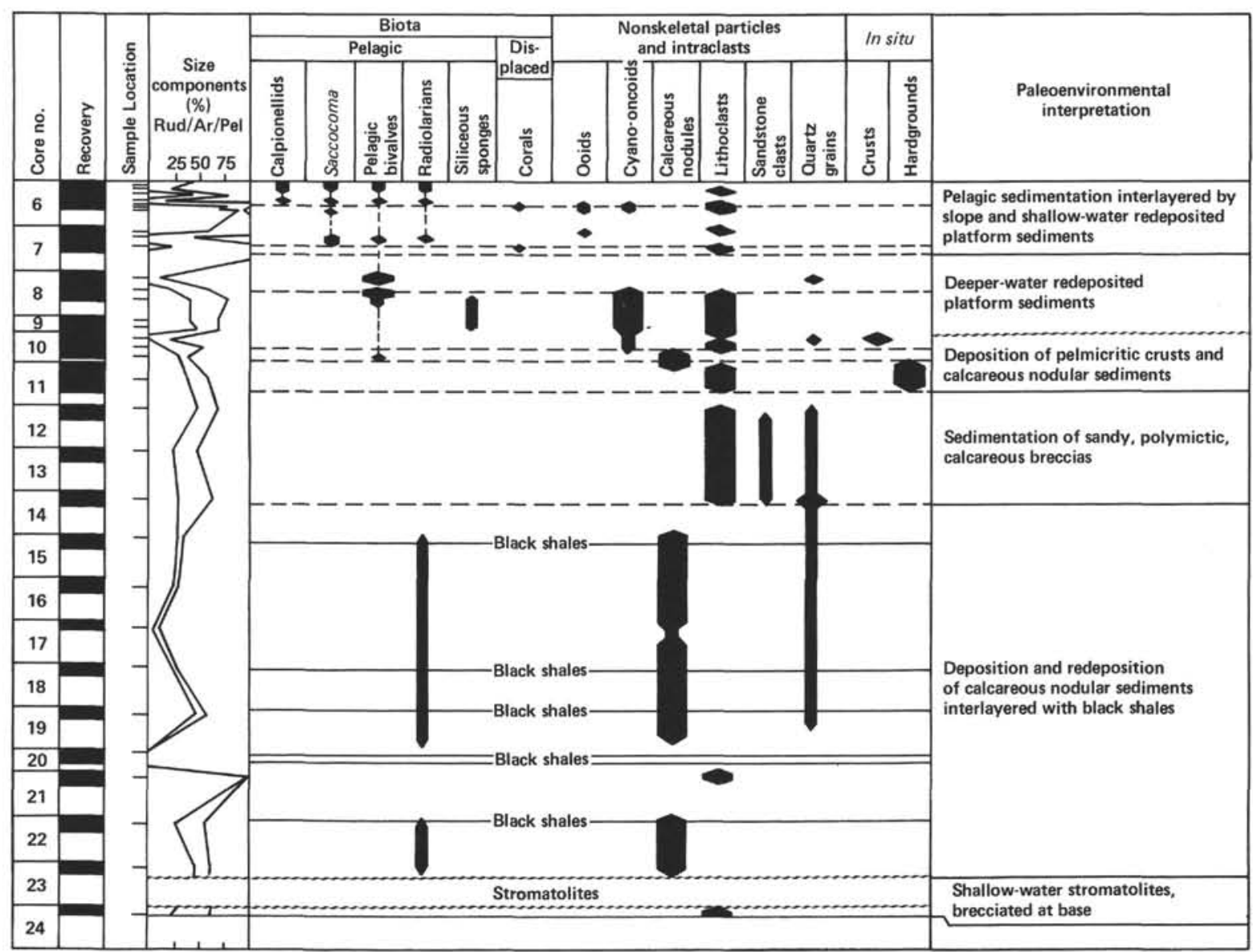

Figure 13. The sedimentological characteristics of Hole 547B Jurassic limestones and their environmental interpretation.

cies with autochthonous pelmicritic crusts were contemporaneously formed at both sites.

Above the crusts, redeposited intervals demonstrate progressive deepening of the carbonate platform slope and landward retreat of the paleoshelf slope. Three types of redeposited sediments demonstrate this process: (1) Proximal, ungraded, coarse breccias of reworked cyanooncoid-sponge facies suggest deposition close to the deeper platform edge. (2) Graded, fine-grained turbidites in the Saccocoma facies contain shallow-water derived allochems. The texture of the turbidites suggests distal deposition and long-distance transport and possibly reflects greater depth and a retreating shelf edge. (3) The uppermost redeposited sediments, found in the calpionellid facies of Subunit A, are dominated by coarsegrained pelagic allochems deposited in muddy matrix. Reworking at this time was therefore restricted to the pelagic environment, and defacing of the platform was weak.

\section{CONCLUSIONS}

The limestones drilled during Leg 79 help in understanding the evolution of a deep carbonate platform margin. The geologic events confirmed by the drilling results of Leg 79 indicate (compare Lancelot and Winterer, 1980; Jansa and Wiedmann, 1982):
1. Flooding of the continental red beds in the Early Jurassic (Hole 547B).

2. A regressive phase, probably in the Dogger, indicated by the presence of sandy carbonates (Holes 545 and 547B).

3. Renewed transgression ("Atlantic transgression") in the Late Jurassic, with proximal redeposited sediments in the foreslope areas (Hole 547B) and growth of sponge-crust buildups (Site 544) and coral bioherms (Site 545).

4. Drowning of the platform at the end of the earliest Cretaceous.

Sites 544 and 545 show that deposition was influenced and complicated by tectonism. The oldest structural lineations are of Triassic or Variscan age (Manspeizer et al., 1978; Stets and Wurster, 1982; Seibold, 1982 ) oriented $60^{\circ}$ and $140-160^{\circ}$ (Hinz et al., 1982). They separate tectonic segments 10 to $15 \mathrm{~km}$ wide. It is likely that such a large-scale tectonic framework is responsible for the differentiation of the facies types in the early stages of the Mazagan platform evolution (Fig. 14). The Middle Jurassic is geologically more complex. During this time Lower Jurassic sediments could have been removed by erosion from the Site 544 block, where erosion cut down to the red beds. Terrigenous quartz grains and sandstone clasts deposited in Hole 547B 


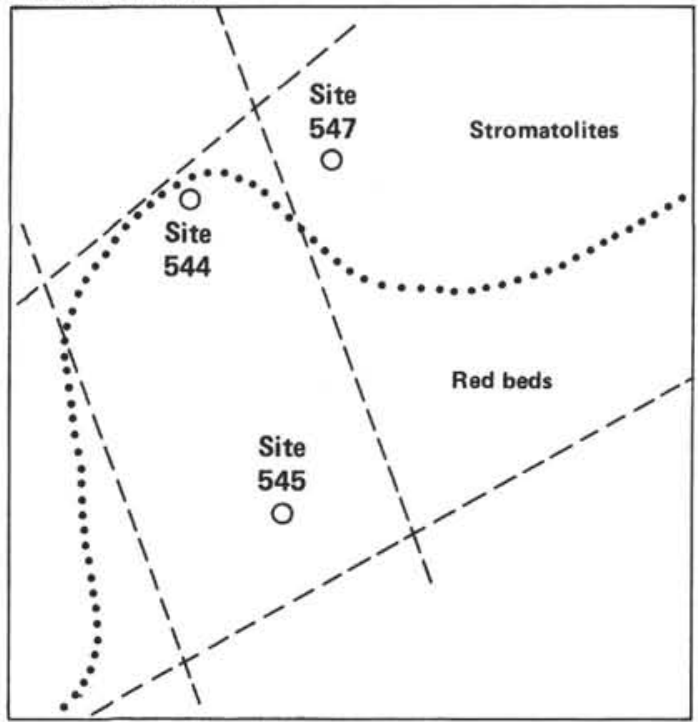

\section{Oxfordian}

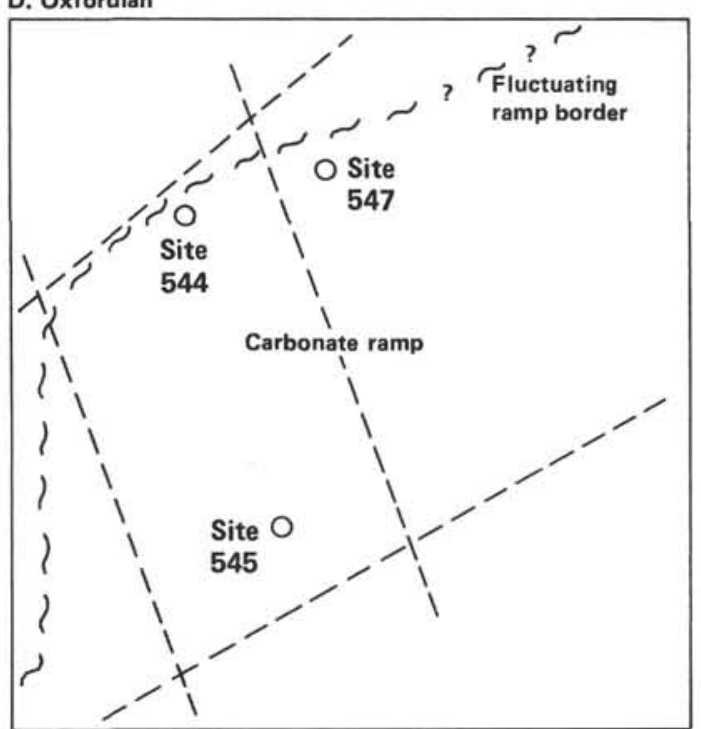

B. Liassic

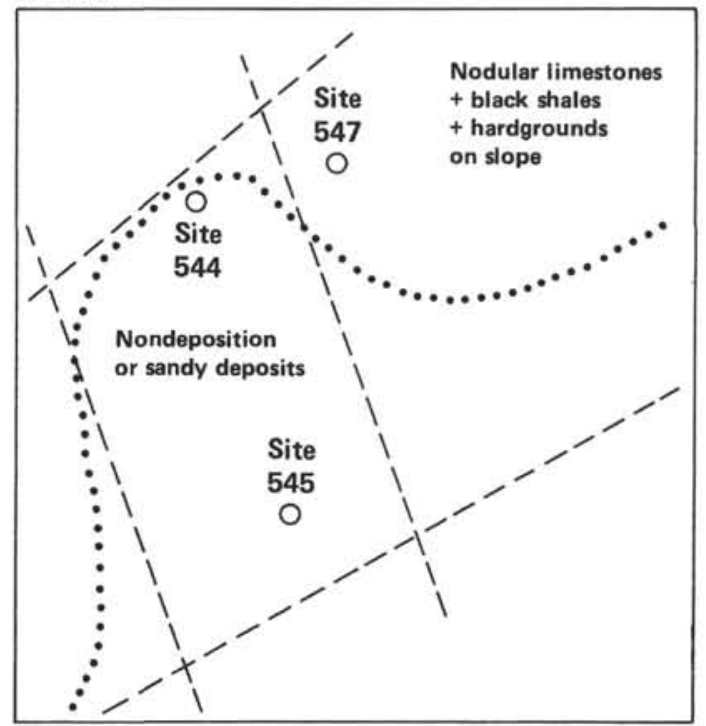

E. Kimmeridgian

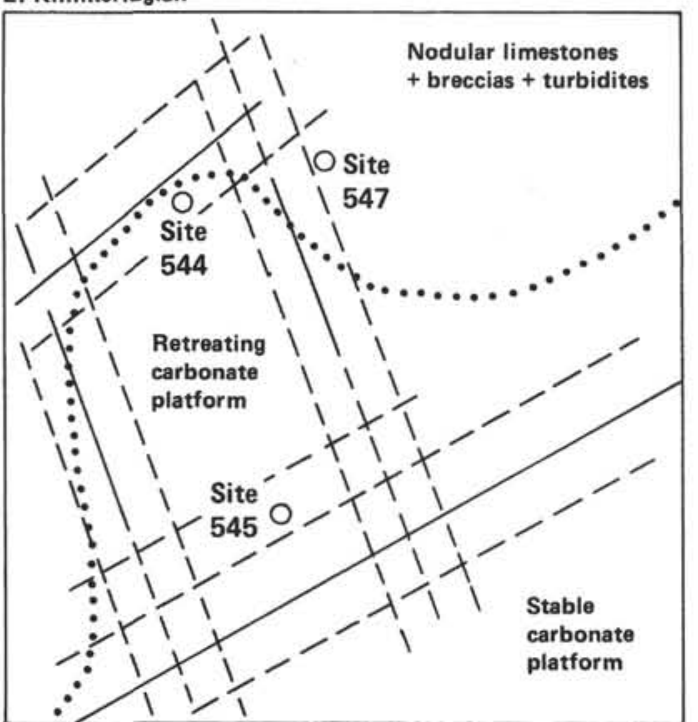

C. Dogger?

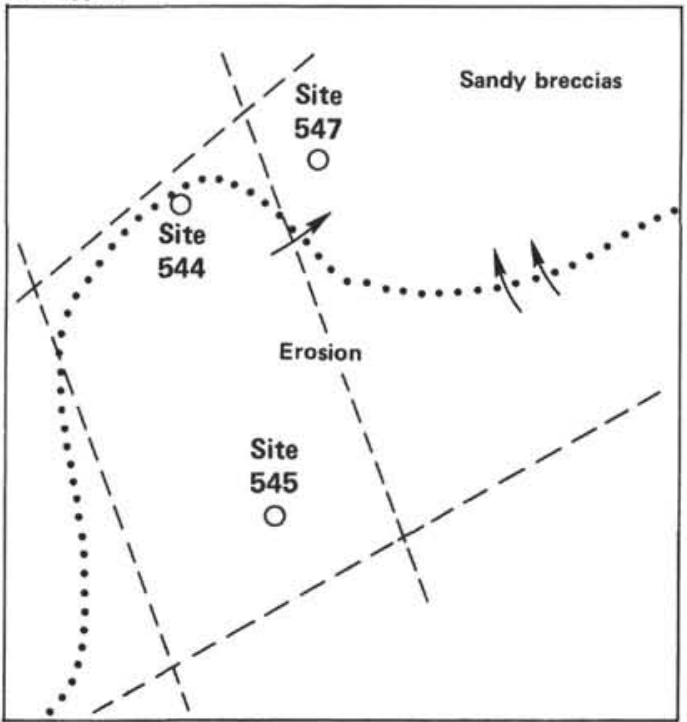

F. Tithonian-Neocomian

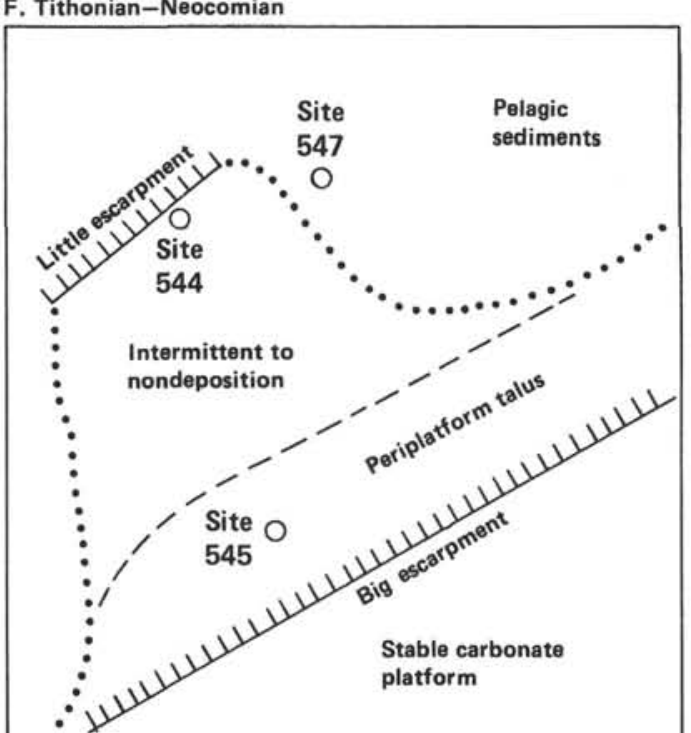

Figure 14. Paleogeographic evolution of the outer Mazagan carbonate platform. A. Triassic/Liassic: Fractures present, but little morphology. Stromatolites and stromatolitic breccias in Hole 547B basin. B. Liassic: Slowly subsiding Site 544 area, rapidly subsiding Site 547 basin with nodular limestones and hardgrounds on the slope. C. Dogger?: Regressive phase. Erosion on slowly subsiding blocks, accumulation on rapidly subsiding blocks. Basin of Site 547 finally filled. D. Oxfordian: Carbonate ramp with peloidal crusts and sponge buildups. Externally fluctuating limits characterized by nodular limestones, hardgrounds, crusts, and proximally redeposited sediments (sponge breccias). E. Kimmeridgian: Beginning of ups. Externally fluctuating limits characterized by nodular limestones, hardgrounds, crusts, and proximally redeposited sediments (sponge breccias). E. Kimmeridgian: Beginning of matolites. F. Tithonian-Neocomian: Subsidence of the Sites 544-545 block. The big Mazagan Escarpment and the little Site 544 escarpment develop. Inner platform remains shallow. The Site 545 area is slowly covered with coarsely brecciated lagoonal sediments. 
came from the surrounding basement highs, whereas pelagic calcareous rock fragments were derived from the surrounding deeper marine slopes.

The period of carbonate platform development started with the Late Jurassic transgression (Ager, 1975; Jansa and Wiedmann, 1982). After the Middle Jurassic regressive phase, the relief between the tectonically elevating blocks and the basin seems to have decreased. In the Oxfordian a carbonate ramp, constructed over the outer Mazagan shelf area, was bordered on the seaward side by peloidal crusts. This was also the time of most extensive carbonate production in the Mazagan area. For a brief time crusts even developed in the Site 547 basin. The occurrence of very proximal slope deposits indicates that sponge-crust buildups grew on the slope close to Hole 547B. The Mazagan platform in general retreated landward during the Late Jurassic. At the Site 544 and Site 545 segment, however, the carbonate platform stage must have been prolonged, because this external block subsided slowly. Here, during the Kimmeridgian and Tithonian, shallow-water carbonates were deposited. Stromatolites represent hypersaline intervals (Site 545) among oolitic and reef environments. Because of the minor thicknesses, these shallow-water conditions seem more likely to be the result of another regressive phase rather than the result of strong platform growth. At the end of the Late Jurassic, the landward movement of the platform margin continued. At this period the Mazagan Escarpment began to form. Whereas the inner carbonate platform was continuously covered by crustose pelsparites and lagoonal debris (CYANA dives; see Auzende et al., this volume), a periplatform talus composed of shallow lagoonal rock fragments accumulated on the upper slope (Site 545). The inner platform margin was intensely defaced at this period. The present morphology of the Mazagan Escarpment is characterized by steps which were probably tectonically controlled. Fractures parallel to the main faults subdividing the slope must have existed at the end of the Tithonian. The outer segments consist of calpionellid-rich slope deposits; the inner segments show rapidly accumulating shallow-water carbonates. The facies boundaries are also tectonically controlled. Defacing of the platform margin was at a reduced rate because of two effects:

1. The progressive development of the Mazagan Escarpment morphology. On the back-tilted blocks, most of the eroded platform material was collected.

2. Older Jurassic platform limestones cropped out during formation of the Escarpment. These fully cemented rocks were very resistant to erosion, and defacing of the platform after the Jurassic was extremely slow. Only a few indications of erosional events are recognized-for instance, calcareous turbidites in the lowermost Cretaceous and debris flows in the Miocene (Fig. $15)$.

\section{ACKNOWLEDGMENTS}

We wish to thank the reviewers, D. Herm (Munich), E. Flügel (Erlangen), L. Happel (Munich), and also D. Bernoulli, for their constructive comments. T. Steiger is very greatful to $\mathrm{H}$. Mertel for preparing exceptional thin sections. Special thanks to Miss B. Kirkland for refining the English text of the paper.

\section{REFERENCES}

Ager, D. V., 1974. The western High Atlas of Morocco and their significance in the history of the North Atlantic. Geol. Assoc. (London) Proc., 85(1):23-41.

Bacelle, L., and Bosellini, A., 1965. Diagrammi per la stima visiva della composizione percentuale nelle rocce sedimentarie. Ann. Univ. Ferrara, N. S., Sez. IX., Sci. Geol. Paleont., 1/3:59-62.

Bernoulli, D., 1972. North Atlantic and Mediterranean Mesozoic facies: A comparison. In Hollister, C. D., Ewing, J. I., et al., Init. Rpts. DSDP, 11: Washington (U.S. Govt. Printing Office), 801871.

Bernoulli, D., and Jenkyns, H. C., 1970. A Jurassic basin: The Glasenbach Gorge, Salzburg, Austia. Geol. Bundesanst. Wien Verh., 1970, pp. 504-531.

1974. Alpine, Mediterranean and central Atlantic Mesozoic facies in relation to the early evolution of the Tethys. In Dott, R. H., and Shaver, R. H. (Eds.), Modern and Ancient Geosynclinal Sedimentation. Soc. Econ. Paleont. Mineral. Spec. Publ., 19: 128-160.

Dunham, R. J., 1962. Classification of carbonate rocks according to depositional structure. In Ham, W. E. (Ed.), Classification of Carbonate Rocks: A Symposium. Am. Assoc. Pet. Geol. Mem., 1: $108-121$.

Eller, M. G., 1981. The red chalk of eastern England: A Cretaceous analogue of Rosso Ammonitico. In Farinacci, A., and Elmi, S. (Eds.), Rosso Ammonitico Symp. Proc.: Rome (Edizioni Tecnoscienza), pp. 207-231.

Elmi, S., 1981. Sédimentation rythmique et organisation sequentielle dans les ammonitico-rosso et les faciès associés du Jurassique de la Méditerranée occidentale. Interprétation des grumeaux et des nodules. In Farinacci, A., and Elmi, S., (Eds.), Rosso Ammonitico Symp. Proc.: Rome (Edizioni Tecnoscienza), pp. 251-299.

Embry, A. F., and Klovan, E. J., 1972. Absolute water depths limits of late Devonian paleoecological zones. Geol. Rundsch., 61(2).

Flügel, E., 1978. Mikrofazielle Untersuchungsmethoden von Kalken: Berlin (Springer-Verlag).

, 1982. Microfacies Analysis of Limestones: New York (Springer-Verlag).

Flügel, E., and Steiger, T., 1981. An upper Jurassic sponge-algal buildup from Northern Frankenalb, West Germany. In Toohey, D. (Ed.), European Fossil Reef Models. Soc. Econ. Paleont. Mineral. Spec. Publ., 30:371-397.

Folk, R. L., 1959. Practical petrographical classification of limestones. Am. Assoc. Pet. Geol. Bull., 43(1):1-38.

Fritz, G. K., 1958. Schwammstotzen, Tuberolithe und Schuttbreccien in Weissen Jura der Schwäbischen Alb. Arb. Geol. Paläont. Inst., Stuttgart, 13:1-119.

Fürsich, F. T., 1979. Genesis, environments, and ecology of Jurassic hardgrounds. Jb. Geol. Paläont. Abh., 158(1):1-63.

Garcia-Hernandez, M., Lopez-Garrido, A. C., and Oloriz, F., 1981. Etude des calcaires noduleux du Jurassique supérieur de la zone prébétique (Cordillères bétiques, SE de l'Espagne). In Farinacci, A., and Elmi, S. (Eds.), Rosso Ammonitico Symp. Proc.: Rome (Edizioni Tecnoscienza), pp. 419-434.

Garrison, R. E., and Kennedy, W. J., 1977. Origin of solution seams and flaser structure in Upper Cretaceous chalks of Southern England. Sed. Geol., 19:107-137.

Hinz, K., Dostmann, H., and Fritsch, J., 1982. The continental margin of Morocco: Seismic sequences, structural elements and geological development. In von Rad, U., Hinz, K., Sarnthein, M., and Seibold, E., (Eds.), Geology of the Northwest African Continental Margin: Berlin (Springer-Varlag), pp. 34-60.

Jansa, L. F., 1981. Mesozoic carbonate platforms and banks of the eastern North American margin. Mar. Geol., 44:97-117.

Jansa, L. F., and Wiedmann, J., 1982. Mesozoic-Cenozoic -development of the eastern North American and Northwest African continental margins; A comparison. In von Rad, U., Hinz, K., Sarnthein, M., and Seibold, E. (Eds.), Geology of the Northwest African Continental Margin: Berlin (Springer-Verlag), pp. 215269.

Jenkyns, H. C., 1972. Pelagic "oolites" from the Tethyan Jurassic. J. Geol., 80:21-33.

1974. Origin of red nodular limestones (Ammonitico Rosso, Knollenkalke) in the Mediterranean Jurassic: A diagenetic model. 
In Hsü, K. J., and Jenkyns, H. S. (Ed.), Pelagic Sediments: on Land and under the Sea. Int. Assoc. Sedimentol., Spec. Pub., 1: 249-271.

Kennedy, W. J., and Garrison, R. E., 1975. Morphology and genesis of nodular chalks and hardgrounds in the Upper Cretaceous of Southern England. Sedimentology, 22:311-386.

Kinsman, D. J. J., 1966. Gypsum and anhydrite of recent age, Trucial Coast, Persian Gulf. In Rau, J. L. (Ed.), 2nd Symp on Salt (Vol. 1): Cleveland, (Northern Ohio Geol. Soc.), 302-326.

Krumbein, W. E., (Ed.), 1979.Cyanobakterien-Bakterien oder Algen? 1st Oldenburger Symp. Cyanobakterien, 1977, Univ. Oldenburg, Germany.

Kukal, Z., 1975. On the origin of nodular limestone. Calif. Min. Geol., 20:359-368.

Lancelot, Y., Seibold, E., et al., 1977. Init. Repts. DSDP, 41: Washington (U.S. Govt. Printing Office).

Lancelot, Y., and Winterer, E.L., 1980. Evolution of the Moroccan oceanic basin and adjacent continental margin: A synthesis. In Lancelot, Y., Winterer, E.L., et al., Init. Repts. DSDP, 50: Washington (U.S. Govt. Printing Office), 801-821.

Lancelot, Y., Winterer, E. L., et al., 1980. Init. Repts. DSDP, 50: Washington (U.S. Govt. Printing Office).

Logan, B. W., and Semeniuk, U., 1976. Dynamic Metamorphism; Processes and Products in Devonian Carbonate Rocks, Canning Basin, Western Australia. Geol. Soc. Australia, Spec. Publ., 6.

Manspeizer, W., Puffer, J. H., and Cousimer, H. L., 1978. Separation of Morocco and eastern North America: A Triassic-Liassic stratigraphic record. Geol. Soc. Am. Bull., 89:901-920.

Michard, A., 1976. Eléments de Géologie Marocaine. Notes Mem. Serv. Geol. Maroc., 252.

Mullins, H. T., Neumann, A. C., Wilbur, R. J., and Boardman, M. R., 1980. Nodular carbonate sediment on Bahamian slopes: possible precursors to nodular limestones. J. Sed. Pet., 50:117-132.

Peryt, T., 1981. Phanerozoic oncoids: An overview. Facies 4:197-214.

Purser, B. G., 1980. Sédimentation et Diagenése des Carbonates Néritiques Récents (Vol 1): Paris (Soc. Editions Technip).

Renz, O., Imlay, R., Lancelot, Y., and Ryan, W. B. F., 1975. Ammonite-rich Oxfordian limestones from the base of the continental slope off Northwest Africa. Eclogae Geol. Helv., 68(2):431-448.
Riding, R., 1979. Cyanoliths: skeletal oncolites formed by calcified blue-green algae (Abstr.) 2. Symp. Intern. Algues Fossiles, Paris.

Schlager, W., 1980. Mesozoic calciturbidites in Deep Sea Drilling Project Hole 416A: Recognition of a drowned carbonate platform. In Lancelot, Y., Winterer, E. L., et al., Init. Repts. DSDP, 50: Washington (U.S. Govt. Printing Office), 733-749.

Seibold, E., 1982. The Northwest African continental margin: An introduction. In von Rad, U., Hinz, K., Sarnthein, M., and Seibold, E. (Eds.), Geology of the Northwest African Continental Margin: Berlin (Springer-Verlag), pp. 3-20.

Seyfried, H., 1980. Über die Bildungsbereiche mediterraner Jurasedimente am Beispiel der Betischen Kordillere (Südost-Spanien). Geol. Rundsch., 69:149-178.

Shearman, D. J., 1966. Origin of marine evaporites by diagnesis. Trans. Inst. Min. Metall., B, 75:208-215.

Stets, J., and Wurster, P., 1982. Atlas and Atlantic: Structural relations. In von Rad, U., Hinz, K., Sarnthein, M., and Seibold, E., (Eds.), Geology of the Northwest African Continental Margin: Berlin (Springer-Verlag), pp. 69-85.

Trurnit, P., 1968. Pressure solution phenomena in detrital rocks. Sed. Geol., 2:89-114.

Tucker, M. E., 1974. Sedimentology of Paleozoic pelagic limestone: The Devonian Griotte (Southern France) and Cephalopodenkalk (Germany). In Hsü, K. J., and Jenkyns, J. C., Pelagic Sediments: on Land and under the Sea. Int. Assoc. Sedimentol. Spec. Publ., 1: 71-92.

Walter, M. R. (Ed.), 1976. Stromatolites. Dev. Sedimentol., 20.

Wanless, H. R., 1979. Limestone response to stress: Pressure solution and dolomitization. J. Sed. Petrol., 49(2):437-462.

Wissmann, G., and von Rad, U., 1979. Seismic structure, continental basement, and Mesozoic sediments from the Mazagan Plateau off Morocco. "Meteor"-Forsch. Ergebnisse, Reihe C, 31:1-20.

Zankl, H., 1969. Structural and textural evidence of early lithification in fine-grained carbonate rocks. Sedimentology, 12:241-256.

Date of Initial Receipt: November 18, 1983

Date of Acceptance: March 21, 1984 


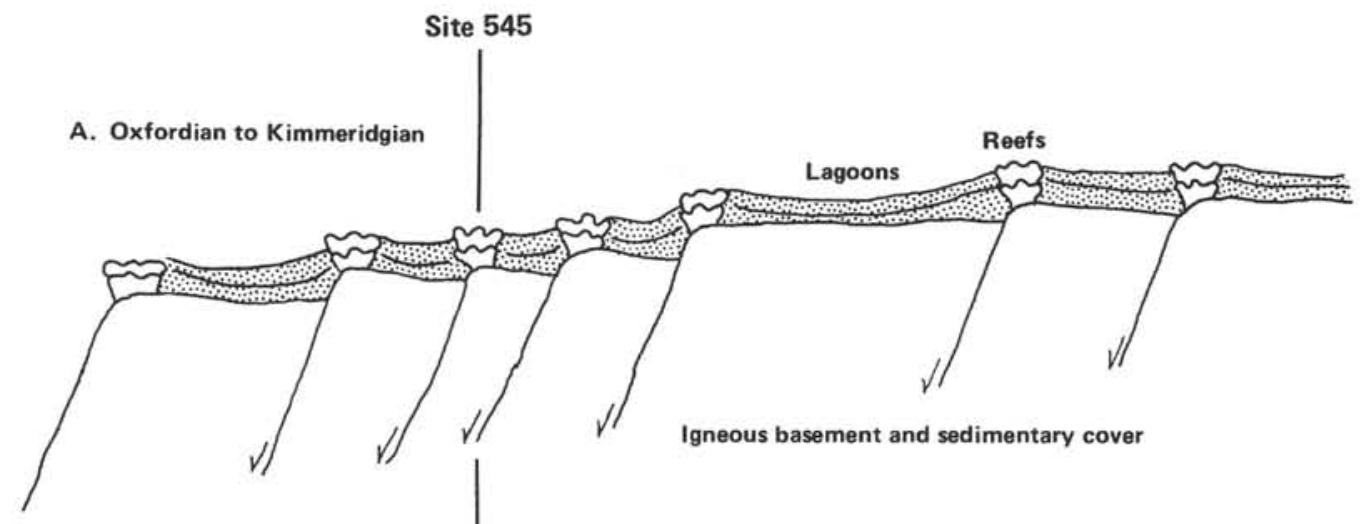

B. Tithonian

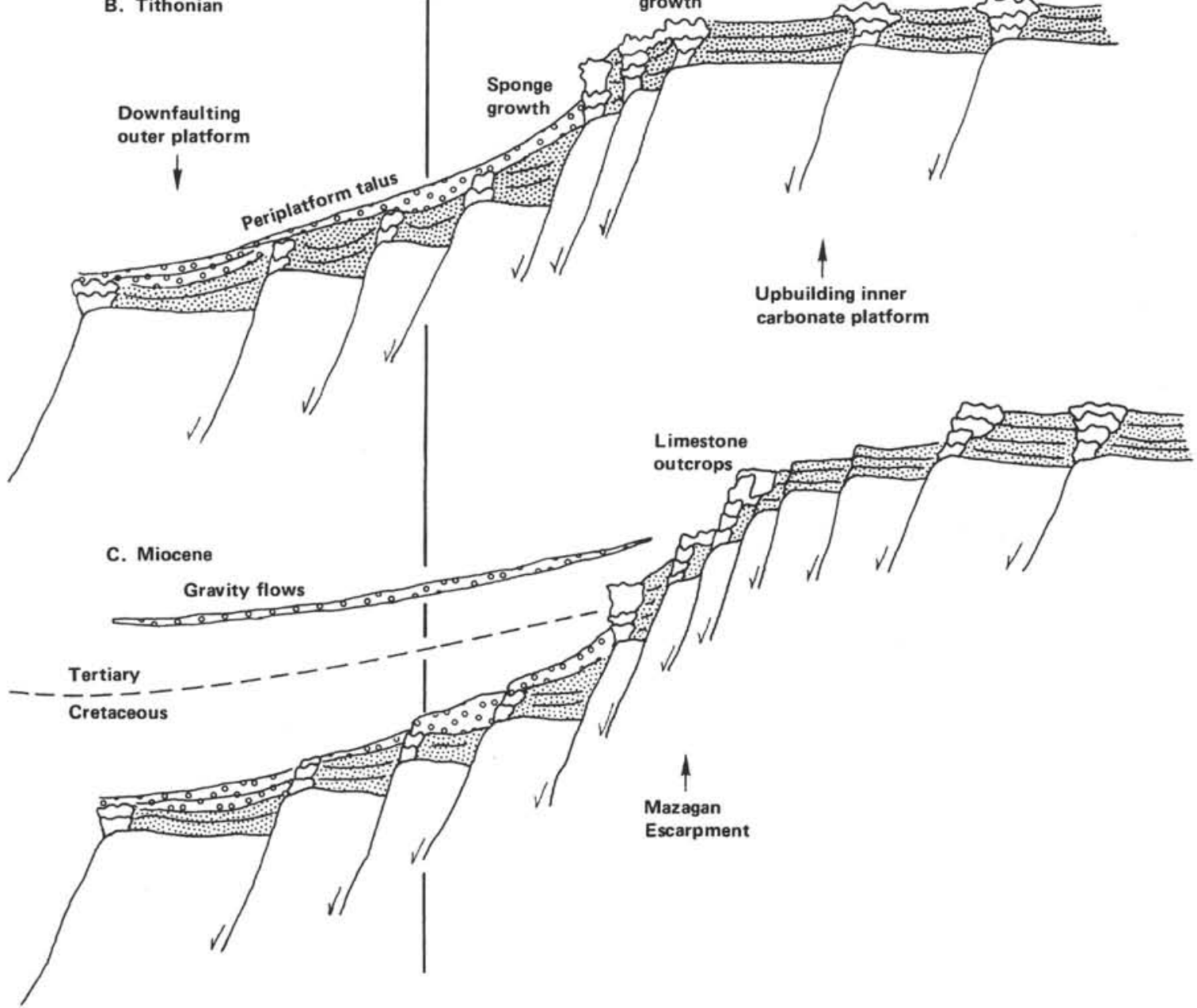

Figure 15. Sedimentological development of the area near the Mazagan Plateau (boundary between inner and outer carbonate platform) from Oxfordian to Miocene (results from Site 545 drilling and Cyana dives). A. Oxfordian to Kimmeridgian: Reefs on top of back-tilting, slowly subsiding tectonic blocks in a carbonate ramp. B. Tithonian: Formation of the Mazagan Escarpment. C. Miocene: Established Mazagan Escarpment is being defaced. 

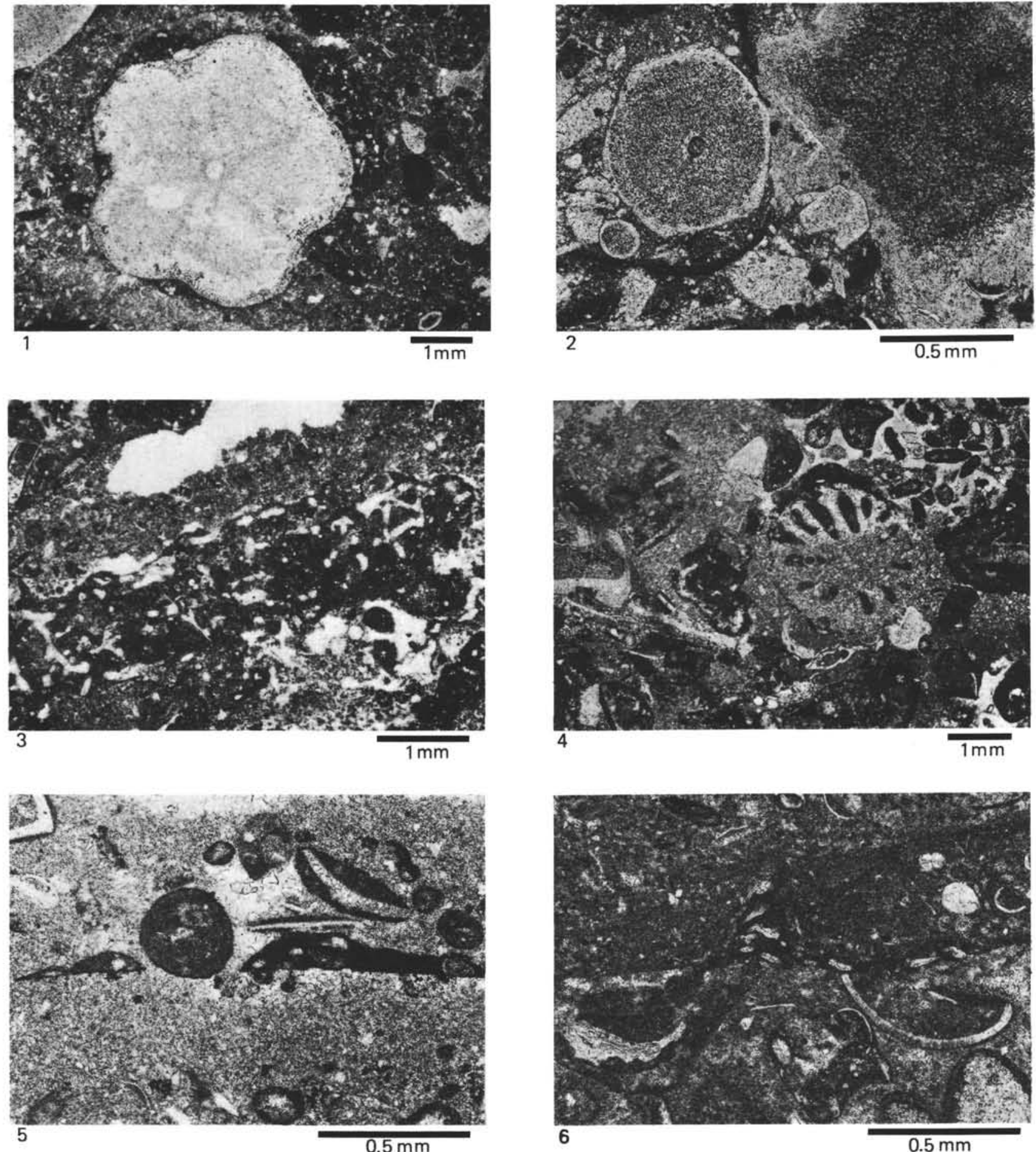

Plate 1. Constituents of Site 544 Oxfordian limestones. 1. Crinoid ossicle, $\times 10$, encrusted by sessile foraminifers and slightly bored; bioclastic (echinoderm-cyano-oncoid) wackestone facies, Sample 544-14-4, 87-94 cm. 2. Crinoid ossicles, $\times 43$, neither bored nor encrusted but overgrown by syntaxial calcite; Sample 544A-14-4, 6-11 cm. 3. Calcified hexactinellid siliceous sponge fragment, $\times 15$; original skeleton partly dissolved and also coated by cyanobacterial micrite; peloidal crust facies, Sample 544-14-4, 72-76 cm. 4. Coral fragment, $\times 10$, dissolved and filled with crystal silt; sessile foraminifers on its top indicate orthotrophic growth of the encrusting organisms in place as the matrix underwent early lithification; bioclastic grainstone facies, Sample 544A-12,cc $(5-12 \mathrm{~cm})$. 5. Sessile miliolid foraminifers, $\times 50$, marking a sedimentary surface within the recrystallized wackestone matrix; Sample 544A-13-1, 106-110 cm. 6. Hardground containing ostracodes and Globochaete alpi$n a$ encrusted by sessile miliolid foraminifers, $\times 50$; Sample 544A-15-1, 121-124. 

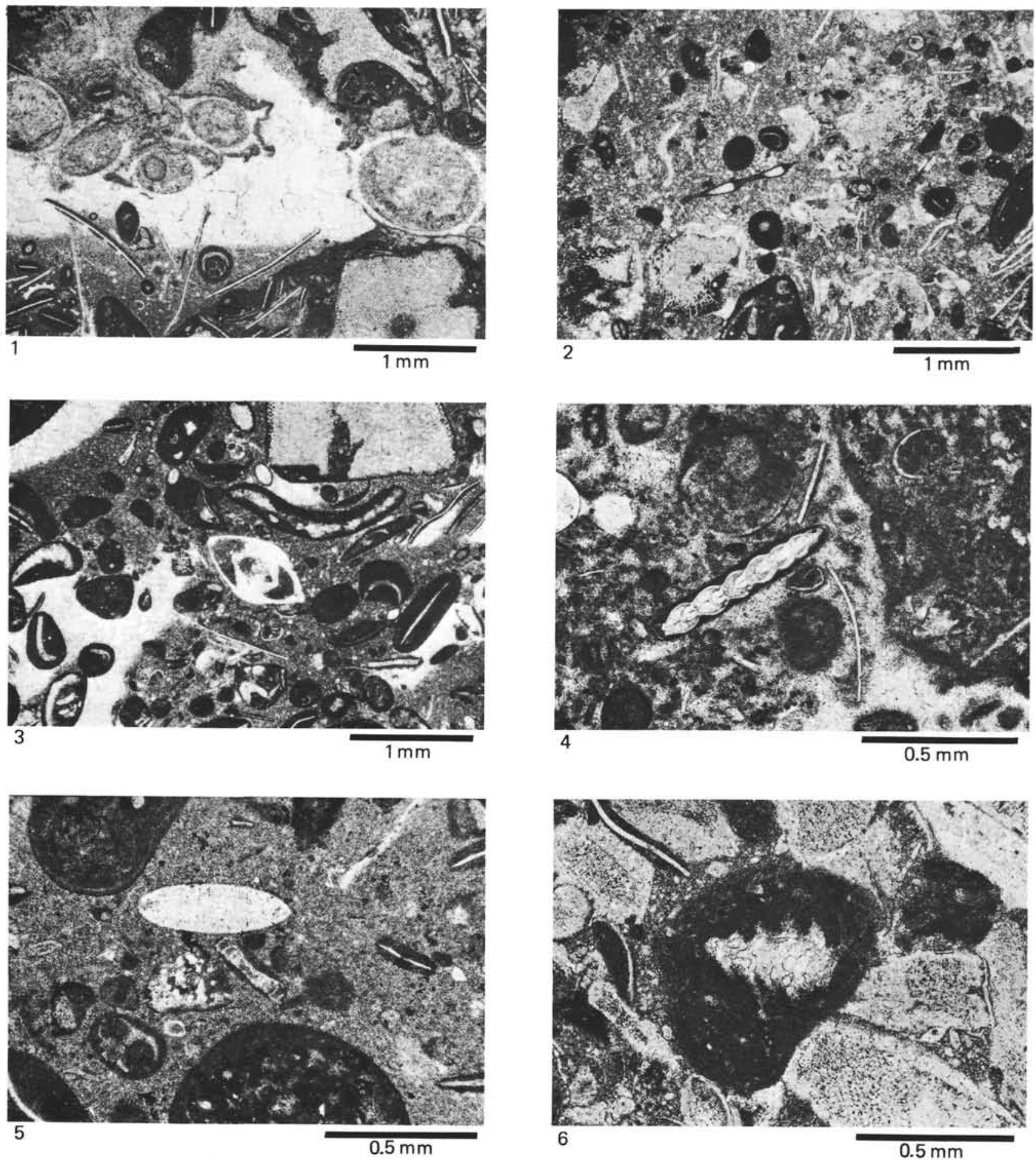

Plate 2. Constituents of Site 544 Oxfordian limestones. $(1-3, \times 20,4-6, \times 50$.) 1. Cavity partially filled with shells of pelagic bivalves, cyanobacterial oncoids, and recrystallized micrite, with serpulids growing from the top into the open space; the walls of the worm tubes are externally dissolved and merge with the sparry calcite cement which fills the void; Sample 544A-14-2, 134-142. 2. Nodophthalmidium sp. in highly recrystallized matrix. Echinoderms and shells of pelagic bivalves are overgrown by epitaxial calcite; bioclastic (pelagic bivalve-cyano-oncoid) wackestone facies, Sample 544A-13-1, 93-100 cm. 3. Lenticulina sp.; bioclastic (foraminiferal-cyano-oncoid) grainstone facies, Sample 544A-13-1, 106$110 \mathrm{~cm}$. 4. Uniserial nodosariid thinly coated by cyanobacterial micrite; peloid crust facies, Sample 544A-13-1, 22-27 cm. 5. Spirillina sp. The ostracode above is totally recrystallized and filled with sparry calcite; Sample 544A-13-1, 106-110. 6. Trocholina sp. enclosed in a cyanobacterial oncoid, the cortex of which contains coarse sedimentary material; Sample 544A-14-4, 6-11 cm. 


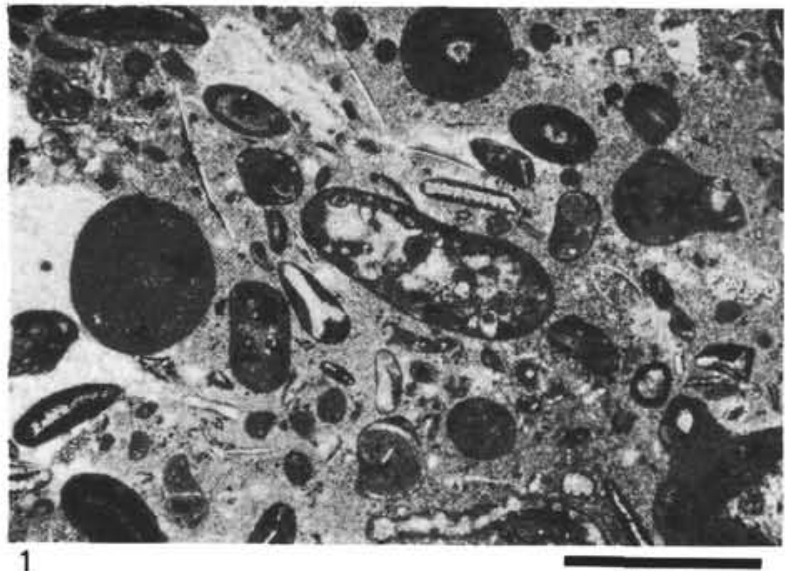

$1 \mathrm{~mm}$
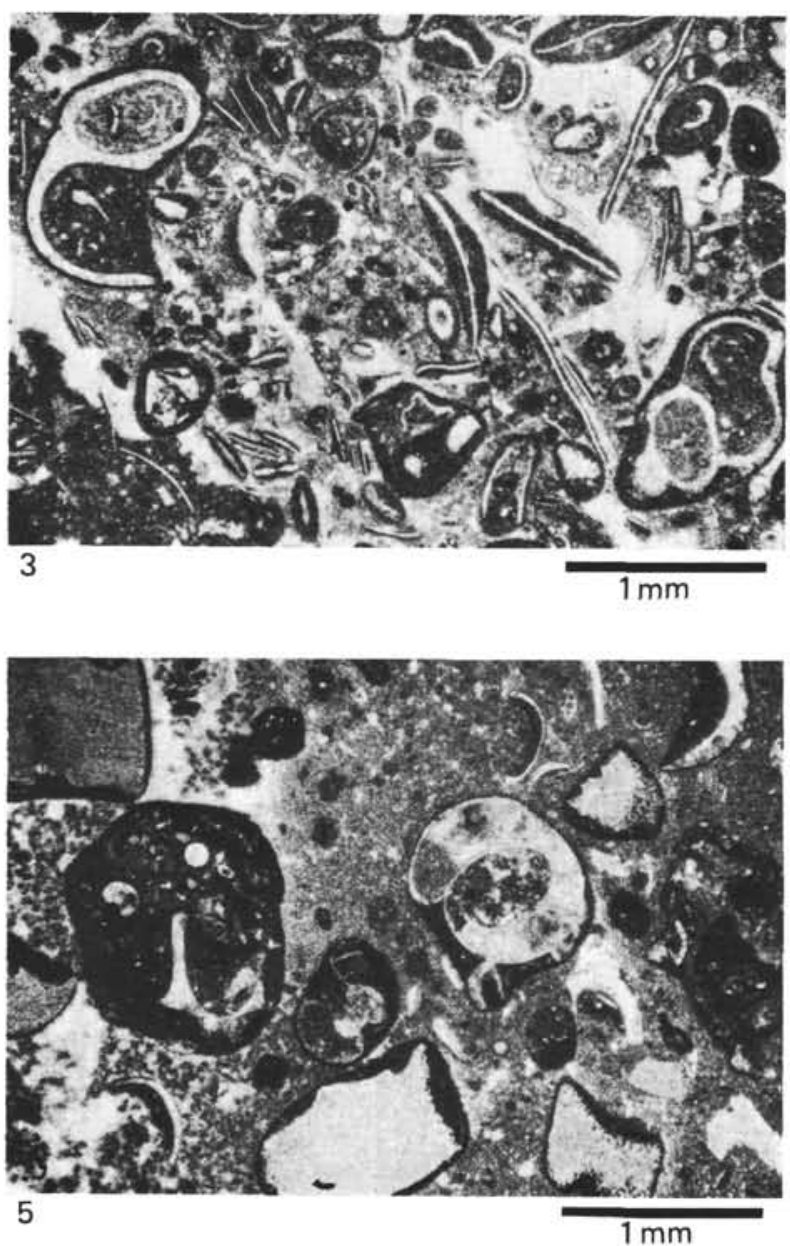

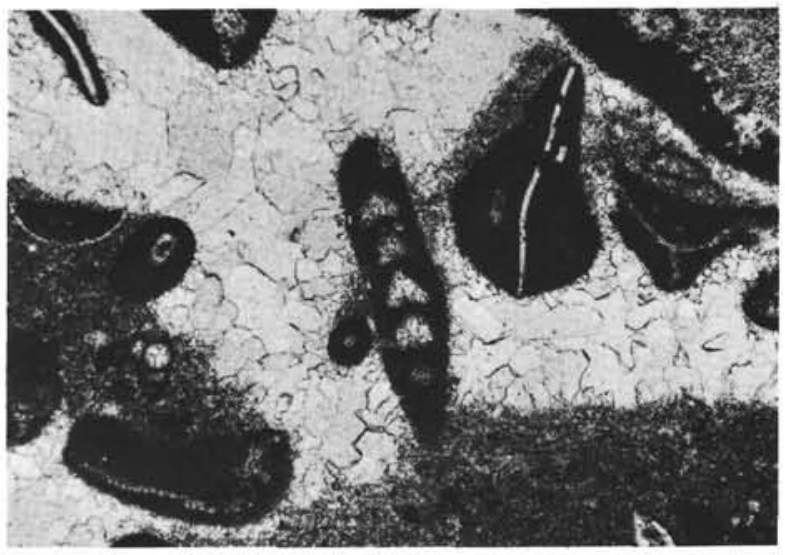

2

$0.5 \mathrm{~mm}$

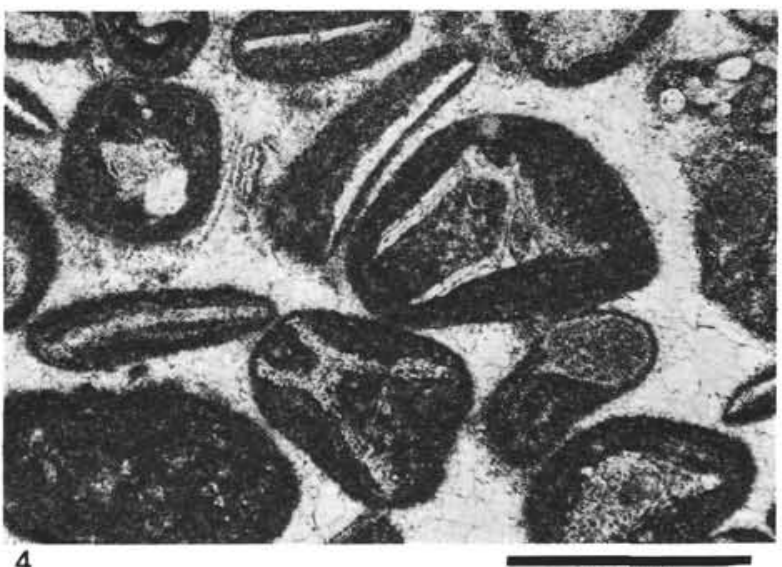

$0.5 \mathrm{~mm}$

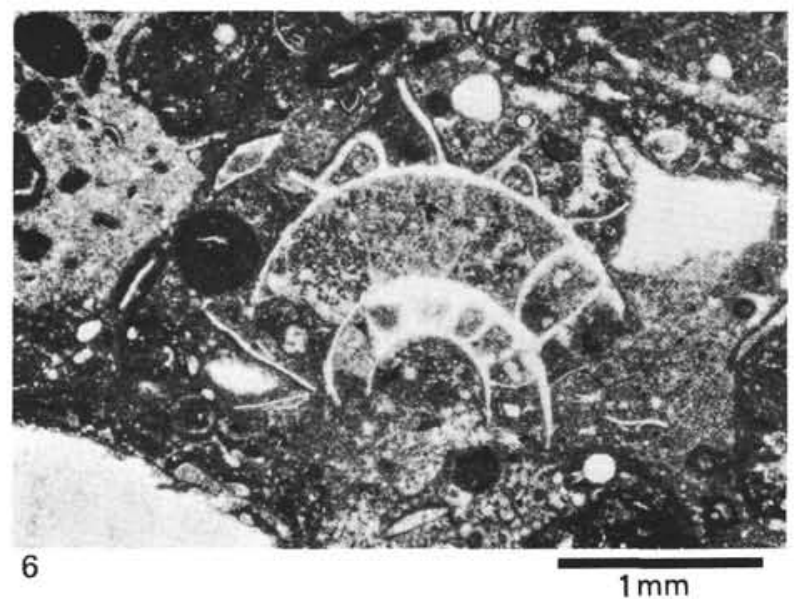

Plate 3. Constituents of Site 544 Oxfordian limestone. 1. Ammobaculites sp. (center), $\times 20$, showing thick, simple agglutinated mass composed of bioclasts, ostracode shells, and peloids; bioclastic (echinoderm-cyano-oncoid) grainstone facies, Sample 544A-13-1, 100-110 cm. 2. Rheophax sp., $\times 50$, as a cavity-filling particle; Sample $544 \mathrm{~A}-13-1,106-110 \mathrm{~cm}$. 3. Gastropods, $\times 20$, filled with microbioclastic sediment and coated by cyanobacterial micrite; bioclastic (pelagic bivalve-cyano-oncoid) grainstone facies, Sample 544A-14-1, 122-126 cm. 4. Saccocoma debris coated by cyanobacterial micrite, $\times 50$. Bioclastic (pelagic bivalve-cyano-oncoid) grainstone facies. Note two generations of sparry calcite: a dirty, bladed, sparry calcite rim after original, aragonitic, early submarine cement, followed by coarse, blocky, sparry calcite interpreted as a late diagenetic cement; Sample 544A-14-3, 114-119 cm. 5. Juvenile ammonites, $\times 20$; Sample 544A-15-1, 121-124 cm. 6. Ammonite fragment, $\times 20$; the aragonite shell was replaced by sparry calcite; Sample $544 \mathrm{~A}-14-3,40-45 \mathrm{~cm}$. 


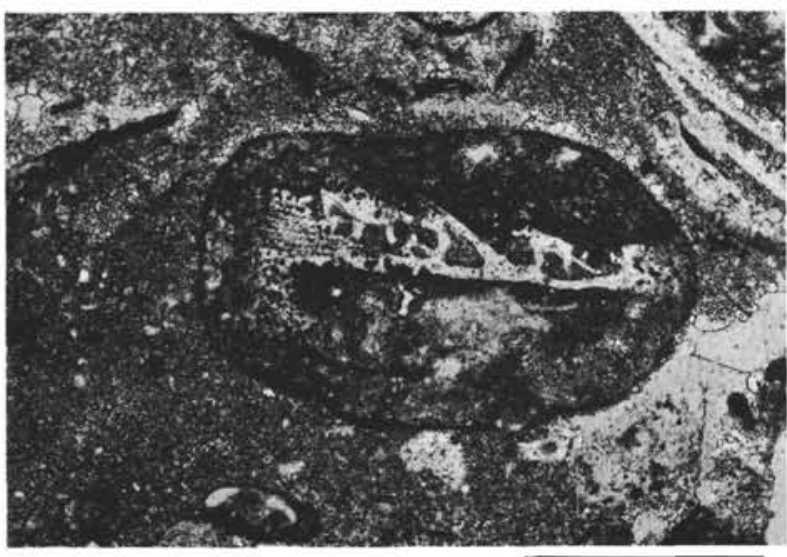

1

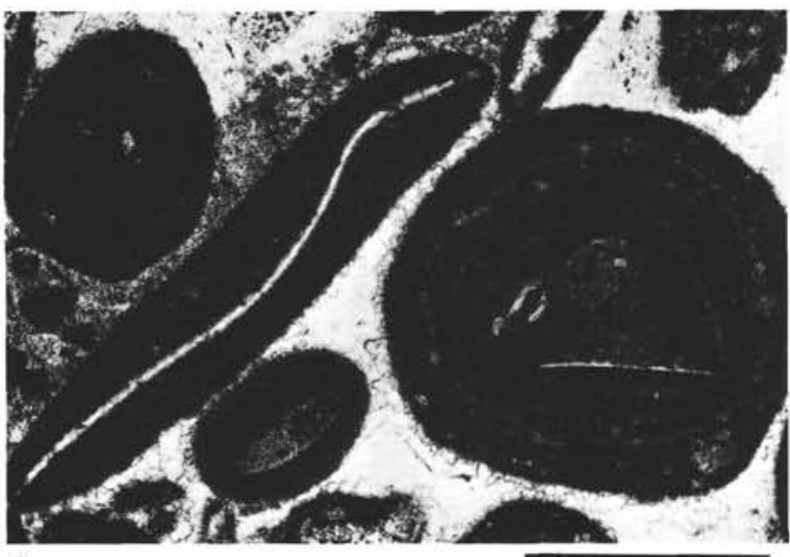

3

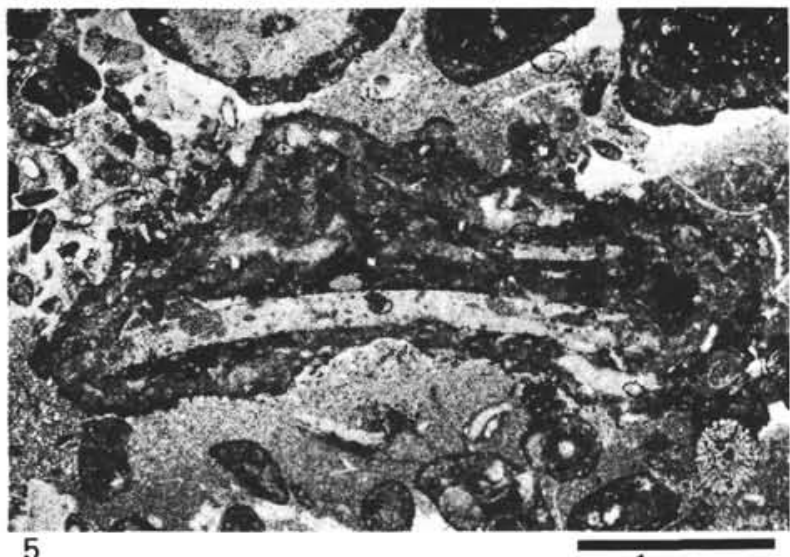

$1 \mathrm{~mm}$

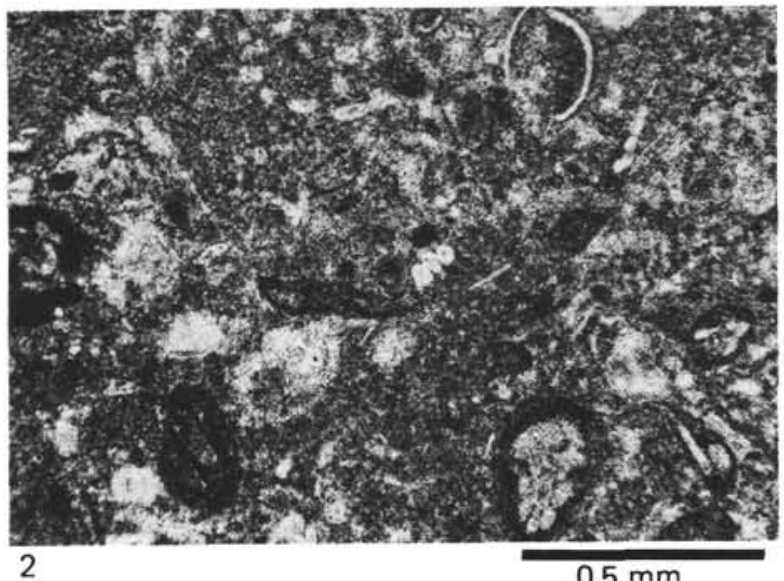

$0.5 \mathrm{~mm}$
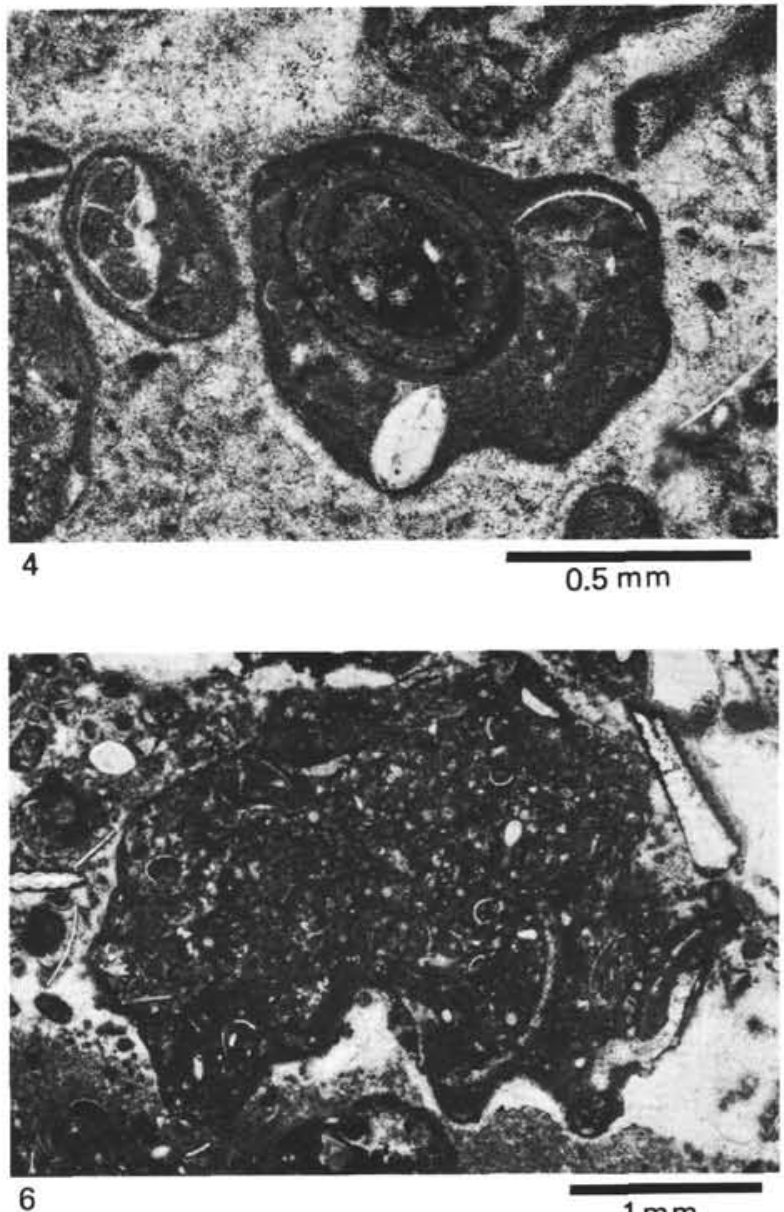

$1 \mathrm{~mm}$

Plate 4. Constituents of Site 544 Oxfordian limestones. $(1-4, \times 50,5-6, \times 20$.) 1. Aptychus fragment as nucleus of a cyanobacterial oncoid; Sample 544A-12, CC (5-12 cm). 2. Globochaete alpina (Lombard), frequently observed in micritic sediments; Sample 544A-13-1, 93-100 cm. 3. Cyanobacterial oncoids containing pelagic bivalve shells and aggregates; cortex consists of spherical, alternating light and dark micrite laminae. The oncoids are similar to "pelagic ooids" of Jenkyns (1972); Sample 544A-14-4, 16-19 cm. 4. Aggregate grain; lump composed of ostracodes, peloids, and a cyanobacterial oncoid coated by cyanobacterial micrite rims; Sample 544A-13-2, 39-44 cm. 5. Cyanobacterial-foraminiferal oncoid composed of cyanobacterial micrite and sessile foraminifers encrusting a highly bored molluscan shell; irregular shape of oncoid is due to binding of other sedimentary and skeletal particles. Sample 544A-12, CC $(5-12 \mathrm{~cm})$. 6. Bioclastic wackestone intraclast, containing ostracodes and Globechaete and forming part of an early lithified surface within the detrital facies, which was broken by currents; Sample 544A-13$1,22-27 \mathrm{~cm}$. 

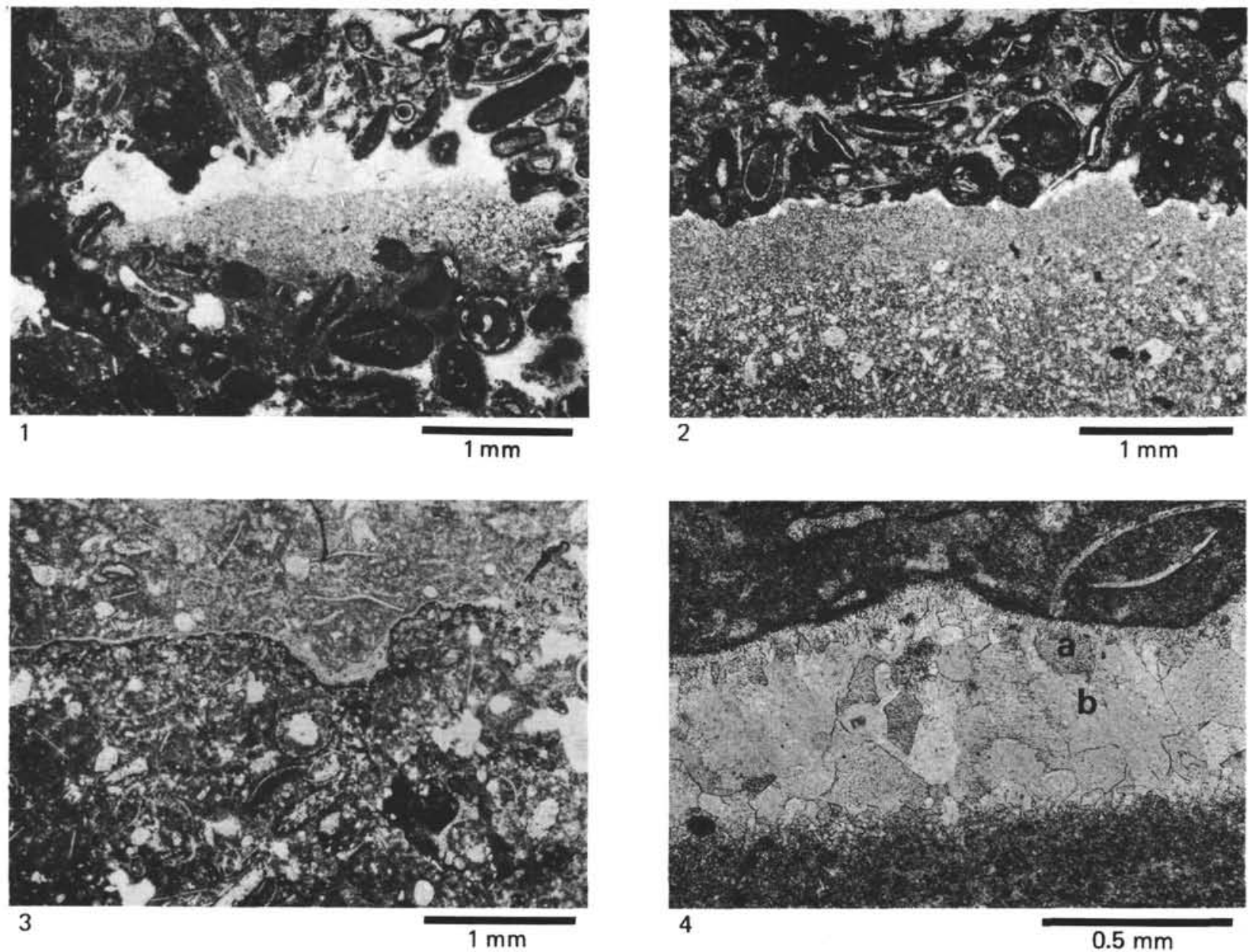

Plate 5. Sedimentary structures in Site 544 Oxfordian limestones. $(1-3, \times 20 ; 4, \times 50$.) 1. Cavity in bioclastic grainstone, probably generated by burrowing; void geopetally filled by "crystal silt" at the bottom and coarse sparry cement above the internal sediment; Sample 544A-13-1, 22-27 $\mathrm{cm}$. 2. Graded internal sediment beneath an early lithified bioclastic grainstone; coarse grains of the internal sediment are calcite rhombs interpreted as diagenetically overgrown echinoderm debris. Filling of the cavity is complete; the sparry rim cement grew from the roof of the cavity during the last phase of internal sedimentation. Sample 544A-13-1, 1-6 cm. 3. Hardground; irregular surface in bioclastic wackestone coated by Fe-Mn oxides and thin calcite layers; Sample 544A-13-1, 22-27 cm. 4. Cements in cavities. Two generations of calcite cement occur: (a) represented by a short, bladed rim which grows on a cyanobacterial micrite layer forming the roof of the cavity, which was later filled by (b) coarse, blocky, sparry calcite that overlies the internal sediment and coarsens toward the center of the cavity; Sample 544A-13-1, 1-6 cm. 

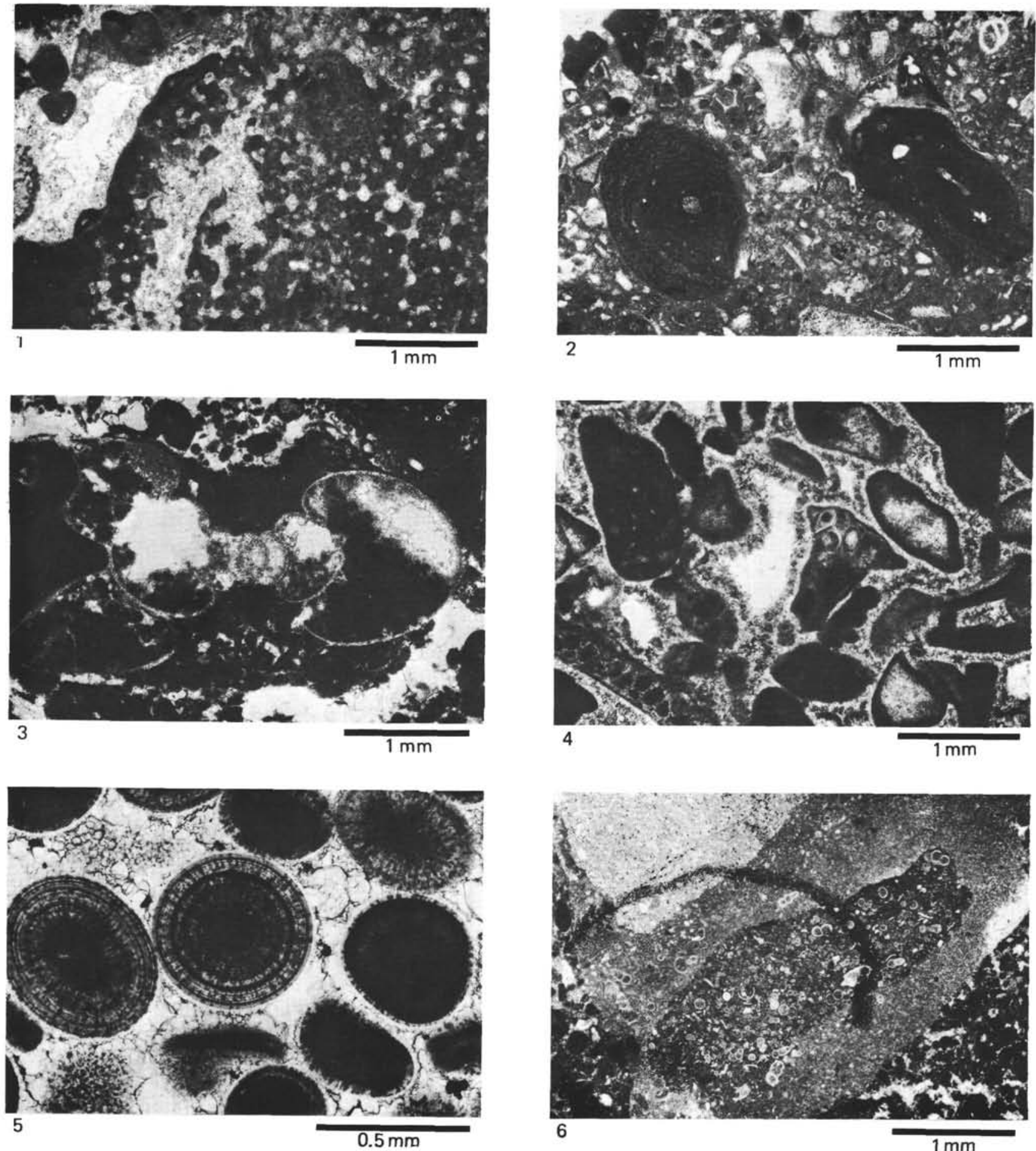

Plate 6. Constituents of Miocene gravity flows in Site 545. (1-4, 6, $\times 20,5, \times 50$.) 1. Calcitized hexactinellid sponge; Tithonian-lowermost Cretaceous, Sample 545-11-1, 46-50 cm. 2. Tubiphytes sp. and calpionellids in bioclastic wackestone; sponge-reef facies, Tithonian-lowermost Cretaceous, Sample 545-15-1, 39-42. 3. Ammonite in a bioclastic grainstone of the sponge-reef facies; Upper Jurassic, Sample 545-11-1, 18-21 $\mathrm{cm}$. 4. Bioclastic grainstones containing intraclasts, fragments of bryozoans, aptychi, and echinoderms; particles cemented by multiple rims of fibrous cement. Upper Jurassic, Sample 545-11-1, 42-49 cm. 5. Shallow-water ooid grainstone cemented by short drusy sparry calcite rims. Upper Jurassic, Sample 545-15-1, 17-21. 6. Upper Cretaceous breccia composed of angular clasts of Jurassic limestones, dolomite, and Cretaceous foraminiferal pelagic limestones embedded in a micritic matrix bearing Upper Cretaceous foraminifers, Sample 545-16-1, 0-3 cm. 

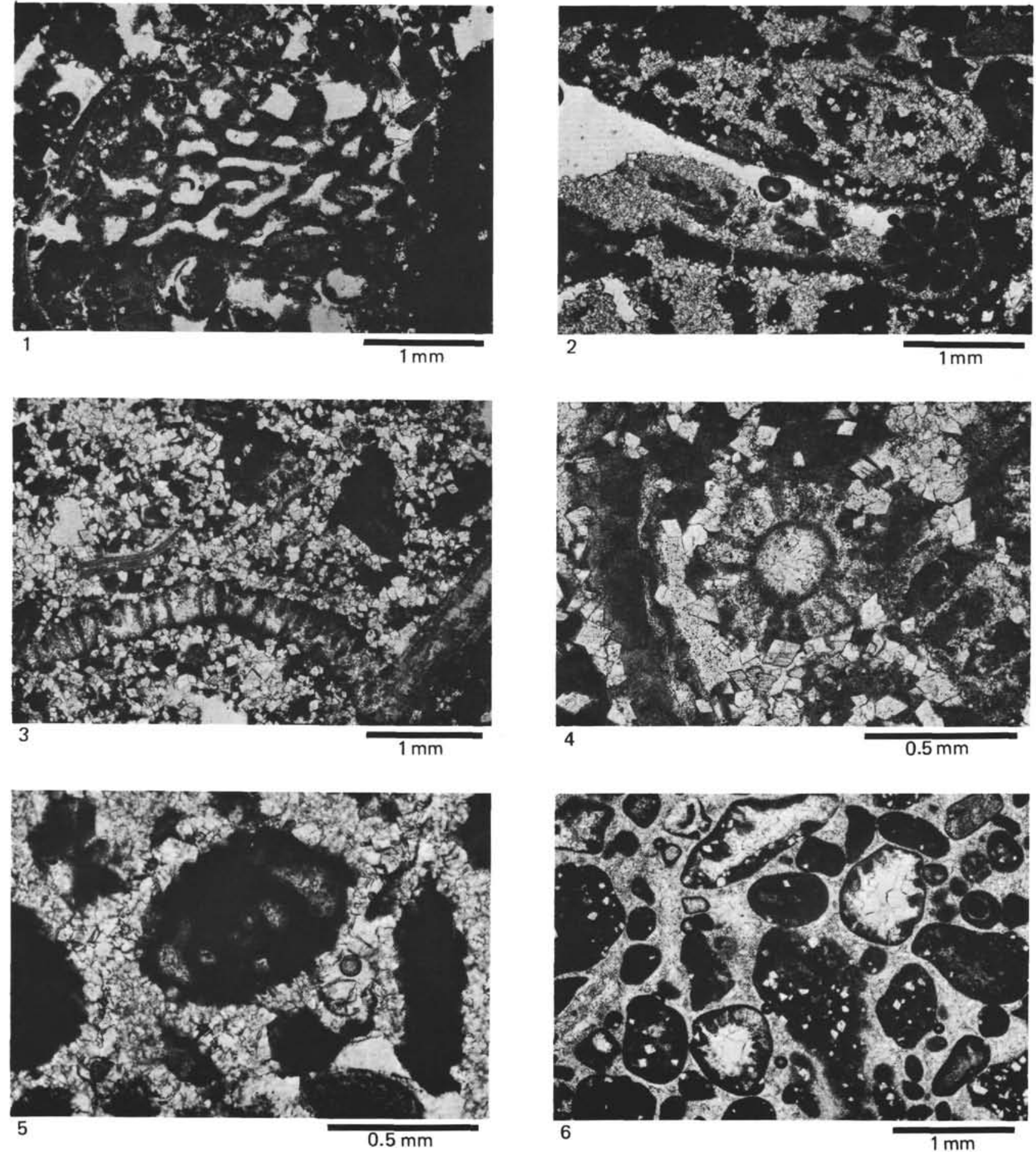

Plate 7. Constituents of Site 545 Upper Jurassic-lowermost Cretaceous limestones. $(1-3,6, \times 20,4-5, \times 50$.) 1. Fragment of the hydrozoan Cladocoropsis mirabilis Felix in porous shallow-water lagoonal grainstones; Sample 545-57-1, 26-31 cm. 2. Dissolved coral fragment in a highly dolomitized shallow-water bioclastic grainstone; coral mold partly filled by dolomite; Sample 545-60-1, 13-15 cm. 3. Dasycladacean algae remains in highly dolomitized shallow-water platform grainstone; Sample 545-57-1, 139-142. 4. Salpingoporella pygmaea Gümbel, Sample 545$62-1,41-43 \mathrm{~cm}$. 5. Nautiloculina oolithica Mohler, Sample 545-60-1, 13-15 cm. 6. Trocholina alpina (Leupold) in well-cemented shallow-water platform grainstones; Growth of dolomite rhombs seen mainly in intraclasts; Sample 545-64-2, 88-91. 

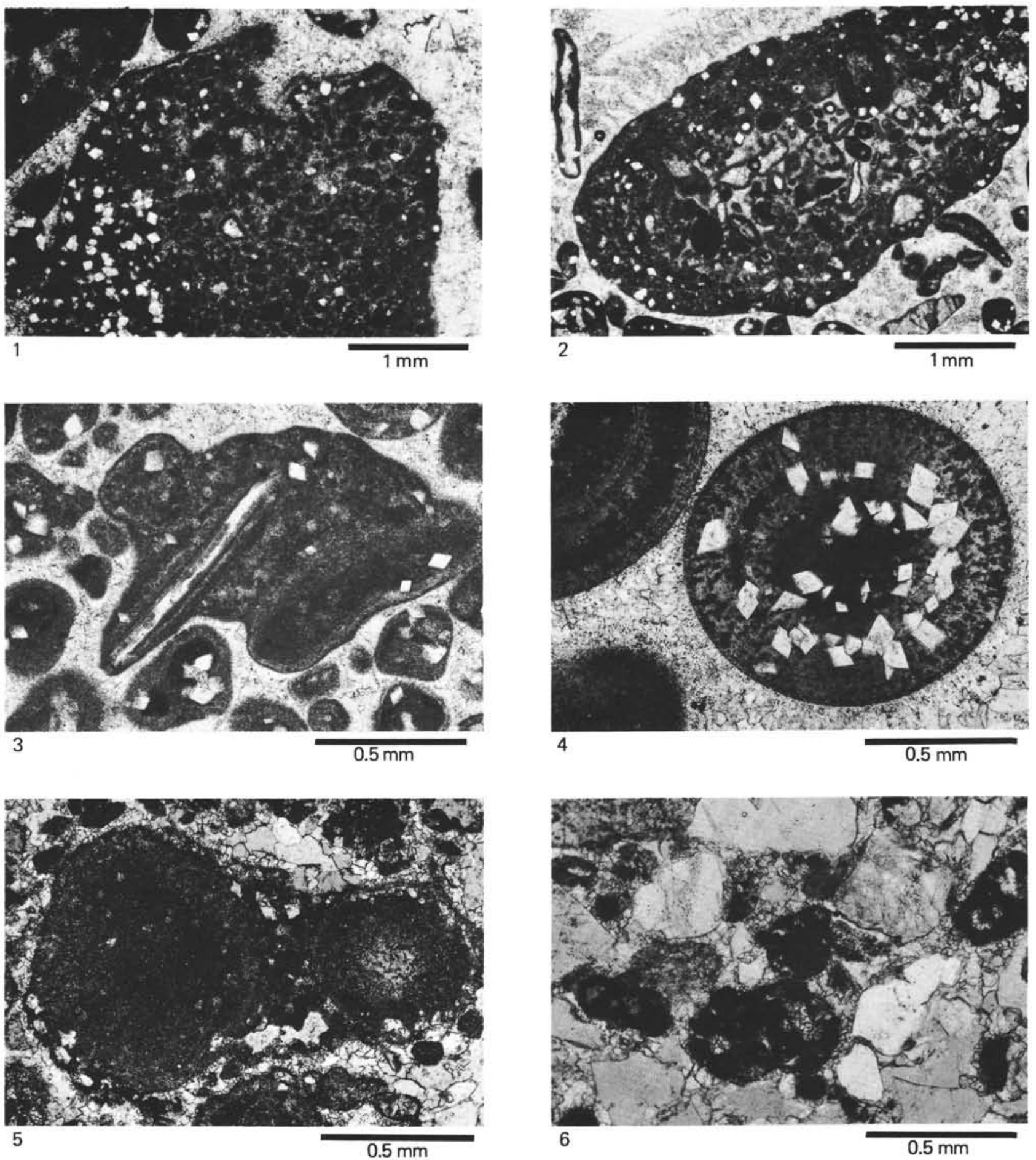

Plate 8. Constituents of Site 545 Jurassic limestones. $(1-2, \times 20,3-6, \times 50$.) 1. Slightly dolomitized intraclast of peloidal packstone; Upper Jurassic-lowermost Cretaceous, Sample $545-64-2,105-108 \mathrm{~cm}$. 2. Slightly dolomitized rounded interclasts of bioclastic packstone coated by pelmicritic crusts; Upper Jurassic-lowermost Cretaceous, Sample 545-64-2, 88-91 cm. 3. Aggregate grain of micritized lenticular shallow-water ooids bound by pelmicrite weakly dolomitized; Upper Jurassic-lowermost Cretaceous, Sample 545-64-2, 88-91 cm. 4. Dolomitized shallow-water ooid; Upper Jurassic-lowermost Cretaceous, Sample 545-64-1, 62-64 cm. 5. Entirely micritized ooids bound by bacterial micrite and encrusted by sessile foraminifers; sandy oolitic packstone facies; Dogger?, Sample 545-71-2, 119-123. 6. Agglutinated foraminifers of $\mathrm{Ammoba}$ culites type in calcareous sandstone within the sandy oolitic facies. Dogger?, Sample 545-72-2, 104-108 cm. 


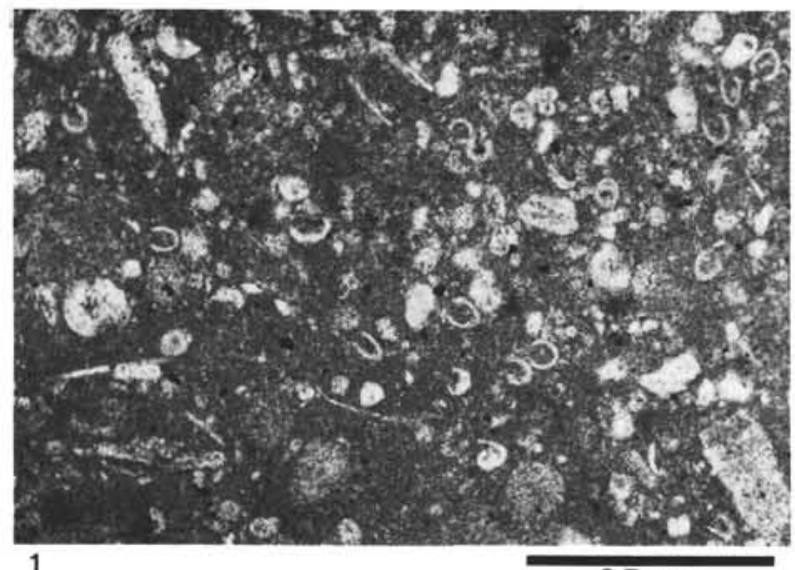

$0.5 \mathrm{~mm}$

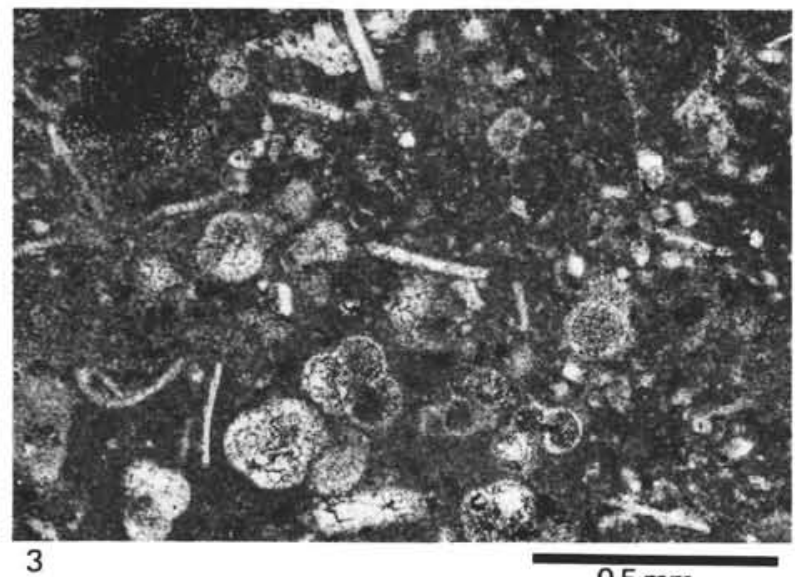

$0.5 \mathrm{~mm}$

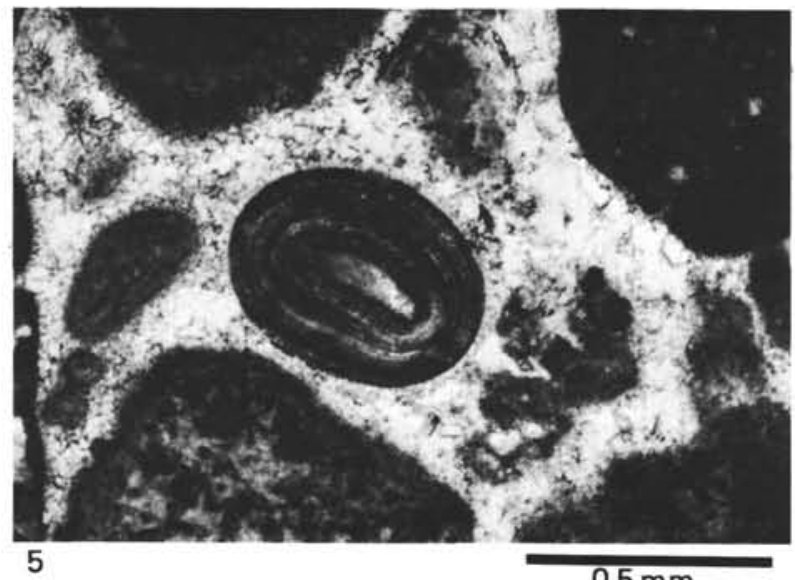

$0.5 \mathrm{~mm}$

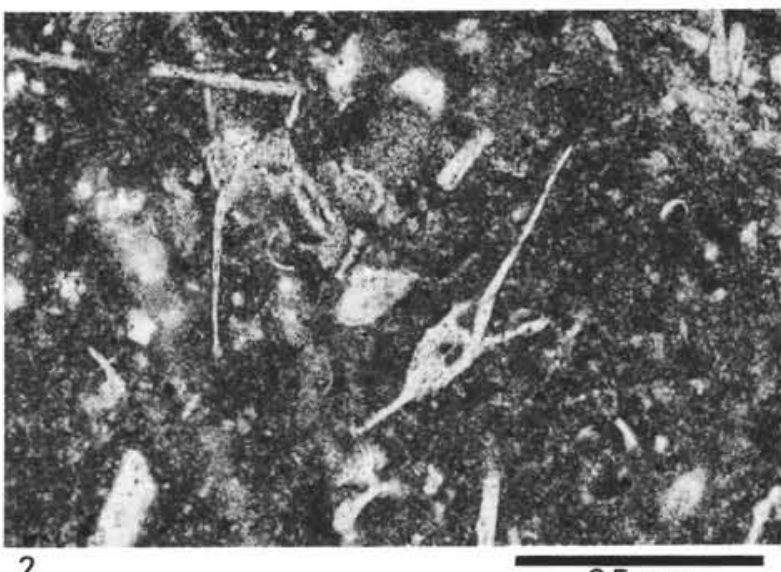

$0.5 \mathrm{~mm}$

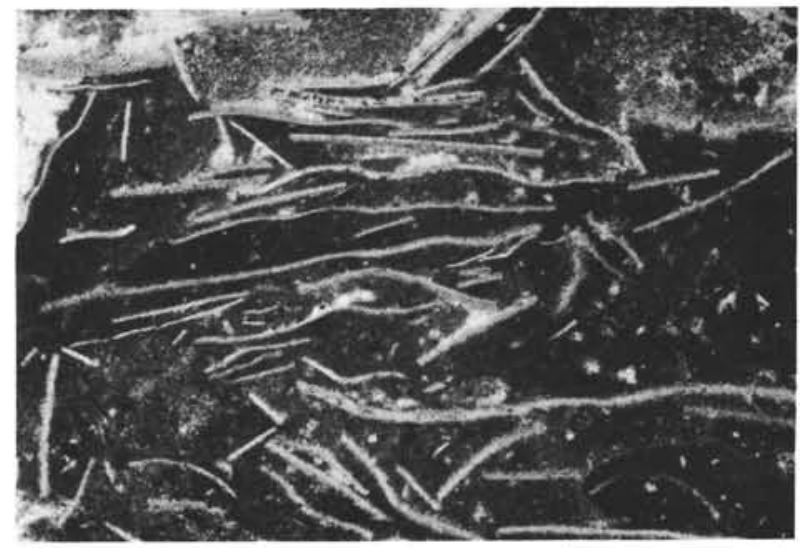

4

$1 \mathrm{~mm}$

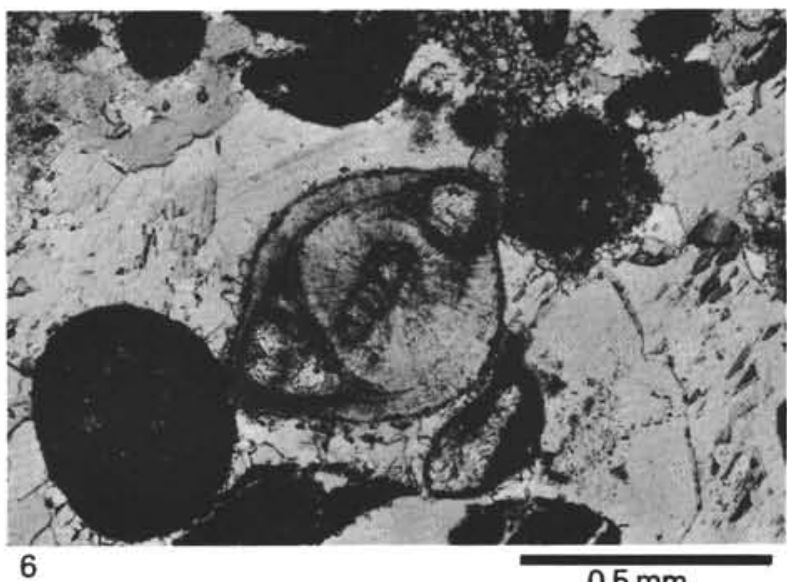

$0.5 \mathrm{~mm}$

Plate 9. Constituents of Hole 547B Upper Jurassic-lowermost Cretaceous limestones. $(1-3,5-6, \times 50,4, \times 20$.) 1. Calpionellids, mostly Calpionella alpina Lorenz and calcite-filled radiolarian molds; pelagic bioclastic wackestone, Sample 547B-6-2, 142-146 cm. 2. Saccocoma fragments; pelagic bioclastic wackestone, Sample 547B-7-2, 69-72. 3. Protoglobigerina sp. and short pelagic bivalve shells; pelagic bioclastic wackestone, Sample 547B-7-2, 69-72 cm. 4. Shells of pelagic bivalves ("filaments"); Sample 547-8-3, 57-61 cm. 5. Shallow-water ooid, component of a calcareous turbidite derived from the carbonate platform; Sample 547B-6-4, 118-120 cm. 6. Protopeneroplis striata Weynschenk in a calcareous turbidite; Sample 547B-7-3, 112-115 cm. 

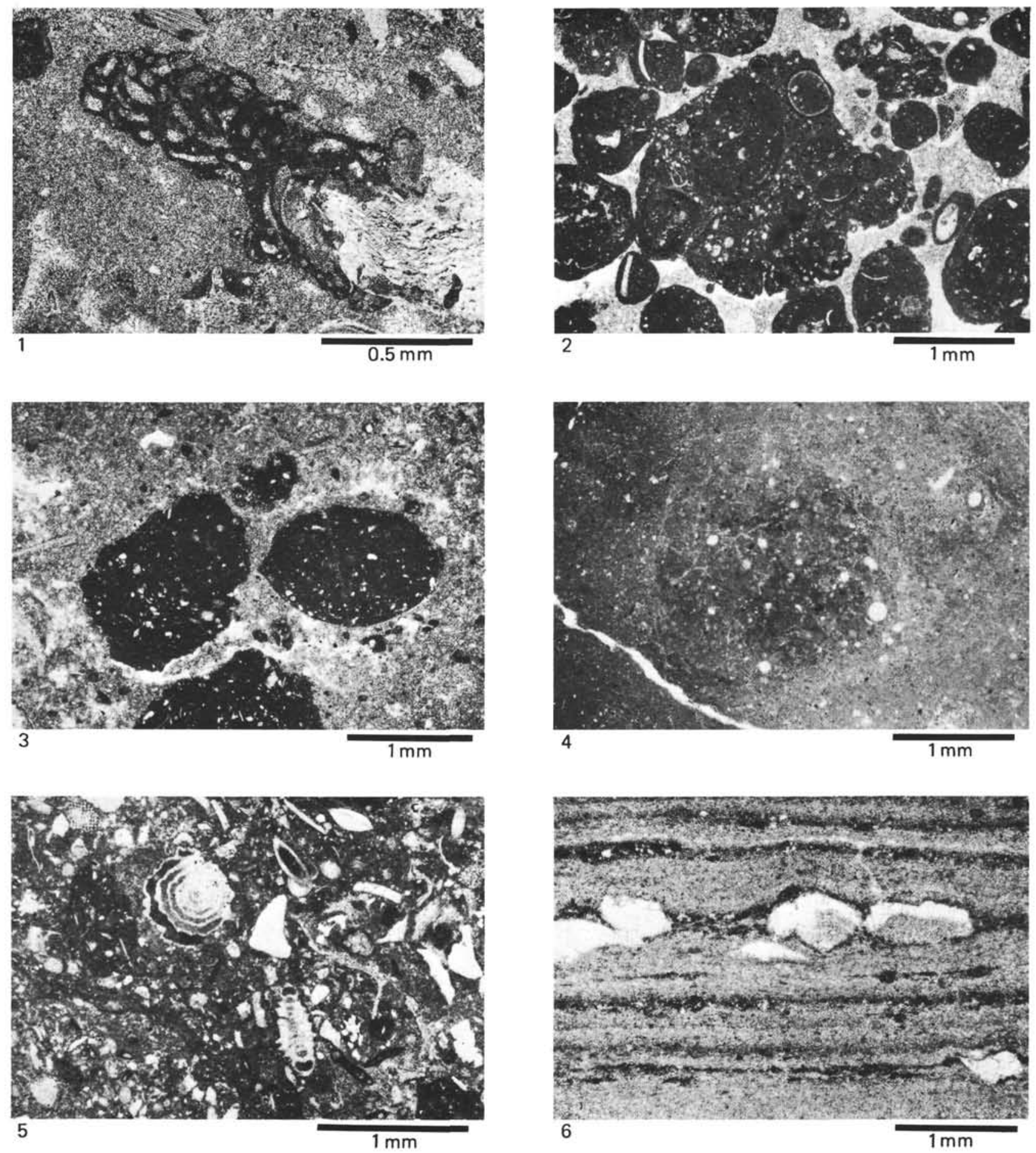

Plate 10. Constituents of Hole 547B Jurassic limestones. 1. Sessile foraminifers, $\times 50$, attached to a molluscan shell fragment; polymictic intraclastic breccia, Oxfordian, Sample 547B-10-1, 22-26. 2. Intraclasts composed of cyanobacterial oncoids and pelmicrite, $\times 20$; intraclastic grainstone facies similar to the cyanobacterial oncoid facies found at Site 544; Oxfordian, Sample 547B-10-2, 130-134 cm. 3. Rounded pelmicritic nodules composed of small bioclasts, radiolarians, and sponge spicules; $\times 20$; matrix highly recrystallized, possibly by pressure solution. Dogger?, Sample 547B-10-4, 16-19 cm. 4. Pelmicritic nodule, $\times 20$, in slightly recrystallized micritic matrix; "nodule" is slightly denser than the surrounding matrix and has no sharp boundary. The dark pelmicrite is concentrated around groups of biota, probably by bioturbation; Lias, Sample 547B-16-2, 126-130 cm. 5. Rock fragment of bioclastic packstone containing sections of Involutina ticinensis Schweihauser, $\times 25$; Lias-Dogger?, Sample 547B-12-1, 35-39 cm. 6. Stromatolite, interlayered light and dark laminae, $\times 20$; dark laminae are rich in pyrite, with sharp upper boundary which reveals minor surface erosion and with ghosts of big crystals, possibly gypsum; Lias, Sample 547B-24, CC (20-25 $\mathrm{cm})$. 

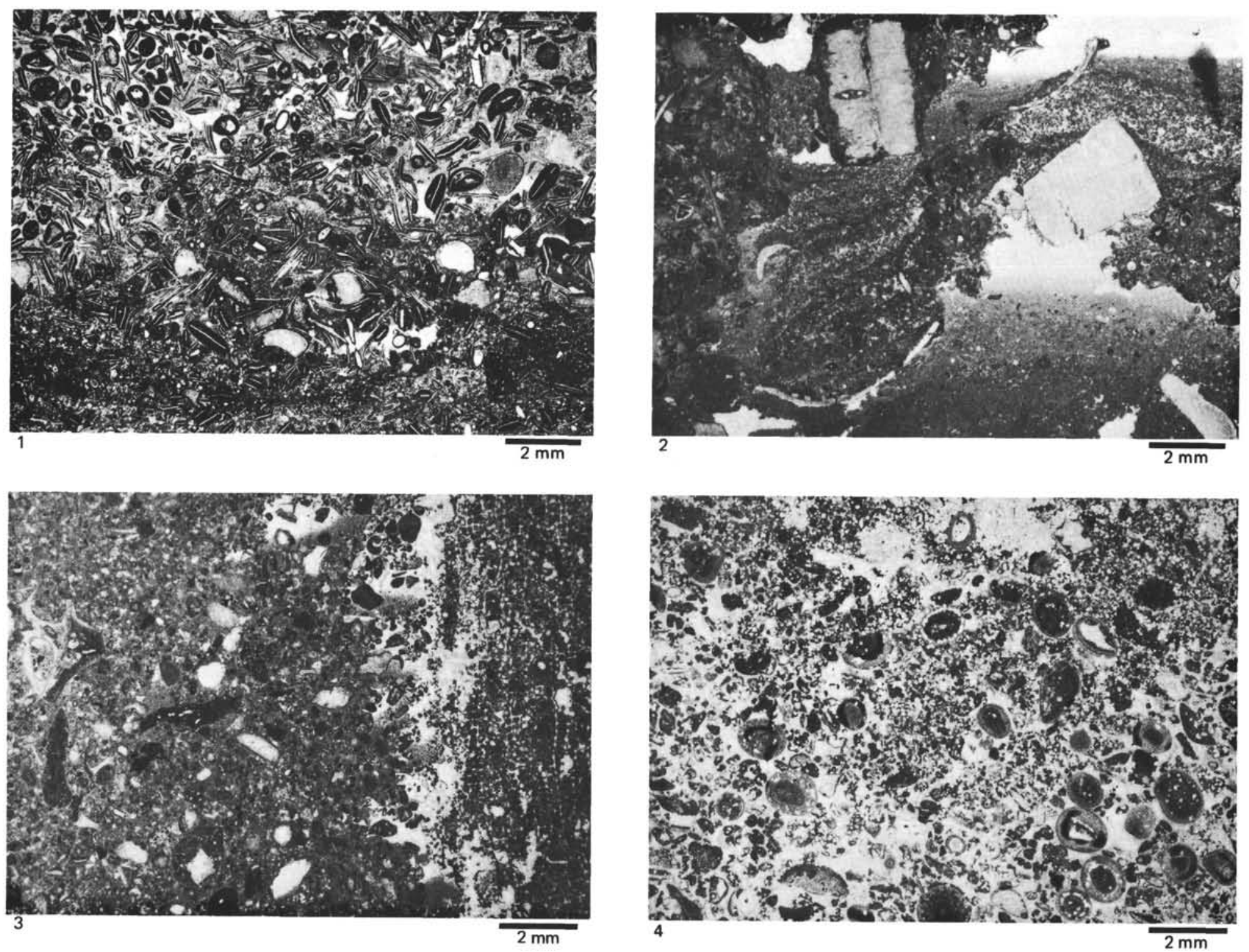

Plate 11. Selected facies types of Holes 544 and 545. ( $\times 7$.$) 1. Pelagic bivalve-cyanobacterial oncoid facies. Bioclastic grainstone containing predominantly echino-$ derms, pelagic bivalves, and cyanobacterial oncoids, in lower part of figure, sedimentary particles are smaller, densely packed, and concentrated in a hardground. Oxfordian, Sample 544A-14-2, 138-142 cm. 2. Peloid-crust facies. Pelmicritic thinly laminated bindstones interlayered with bioclastic oncoids, foraminifers, and other bioclasts are frequently incorporated into the crusts; cavities show graded geopetal filling. Oxfordian, Sample 544A-15-1, 121-124 cm. 3. Siliceous sponge facies. Calcitized siliceous sponges of the hexactinellid group in bioclastic wackestone composed mainly of Tubiphytes, echinoderm remains, serpulid fragments, and intraclasts; small cavities near the sponge show geopetal filling. Tithonian-lowermost Cretaceous, Sample 545-16-1, 53-58 cm. 4. Oolitic facies. Highly dolomitized ooid-bioclastic grainstone composed of shallow-water ooids, echinoderms, shallow-water benthic foraminifers, and dasycladacean algal remains. Poor calcite cementation, high porosity $(\sim 20 \%)$. Kimmeridgian-Tithonian, Sample $545-64-2,55-59 \mathrm{~cm}$. 

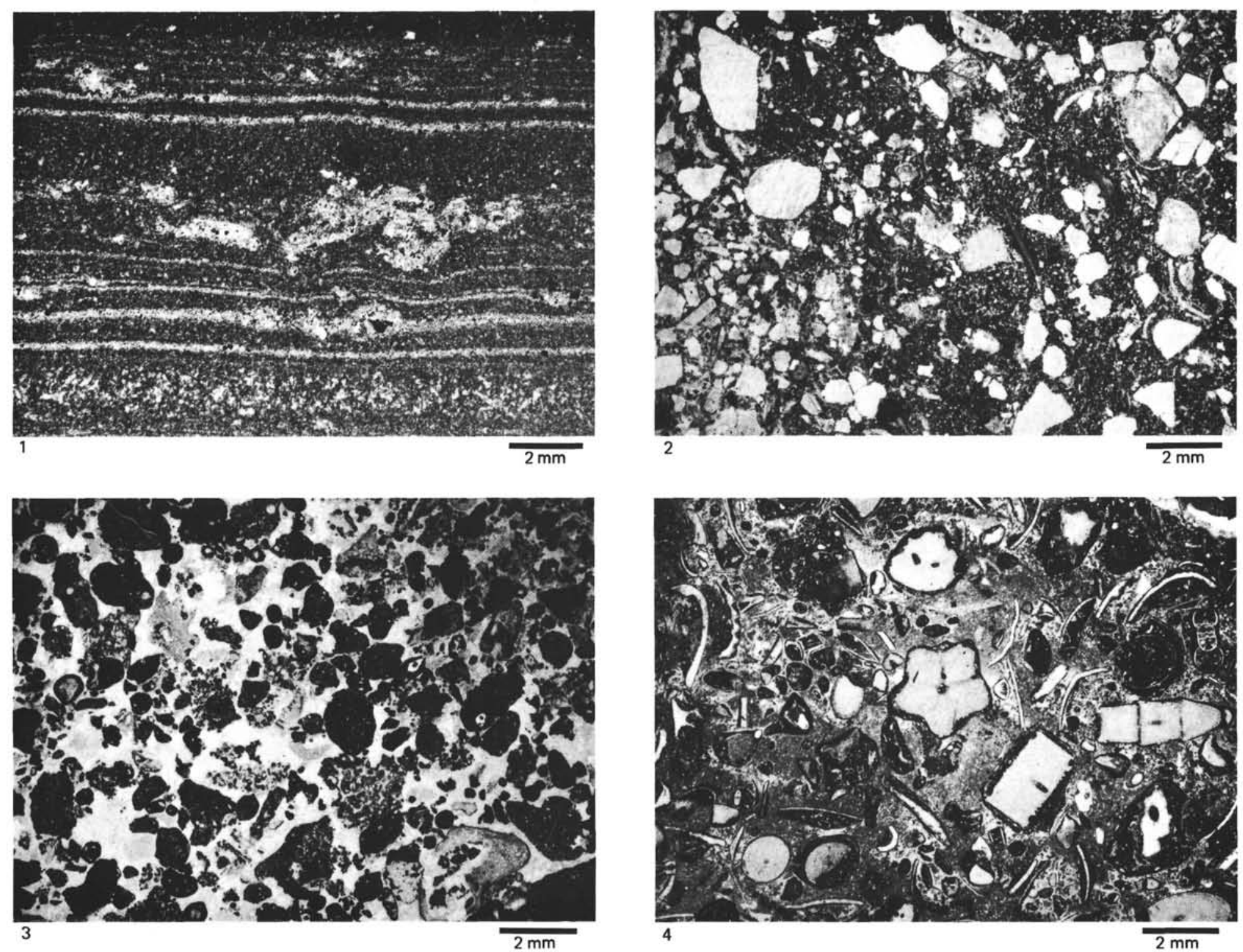

Plate 12. Selected facies types of Holes 545 and 547B $(\times 7$.) 1. Stromatolitic facies. Brown laminated dolomite with interlayers of slightly recrystallized micrite and thin bands of translucent spar; pyrite crystals in sparry zones. Micrite layers are occasionally disturbed by sedimentary, possibly bioclastic particles, which sank into the soft bottom. Dogger?, Sample 545-67-1, 75-80 cm. 2. Sandy peloid wackestone/packstone facies. Calcareous sandstones composed of large angular quartz grains, peloids, thin mollusk shells, arenaceous foraminifers and rare micritized ooids. Layers of densely packed sand grains alternate with calcareous wackestones. Dogger, Sample 545-72-2, 31-36 cm. 3. Calcareous turbidite composed of carbonate debris from deeper-water and shallow-water carbonate platform areas. Lithoclasts are subrounded to subangular microbioclastic wackestones, siliceous sponge fragments, hydrozoan debris, echinoderms, shallow-water ooids and foraminifers; Tithonian. Sample 547B-7-3,111-115 cm. 4. Cyanobacterial oncoid facies. Bioclastic wackestones composed of encrusted pentacrinoid debris, mollusk fers; Tithonian. Sample $547 \mathrm{~B}-7-3,111-115 \mathrm{~cm}$. 4. Cyanobacterial oncoid facies. Bioclastic wackestones composed of encrusted pentacrinoid debris, mollusk
shells, ammonites, brachiopod shells, interclasts, and benthic foraminifers. Most of the components are coated by cyanobacterial micrite, rich in trapped clastic material. Oxfordian, Sample 547B-8-4, 64-69 cm. 

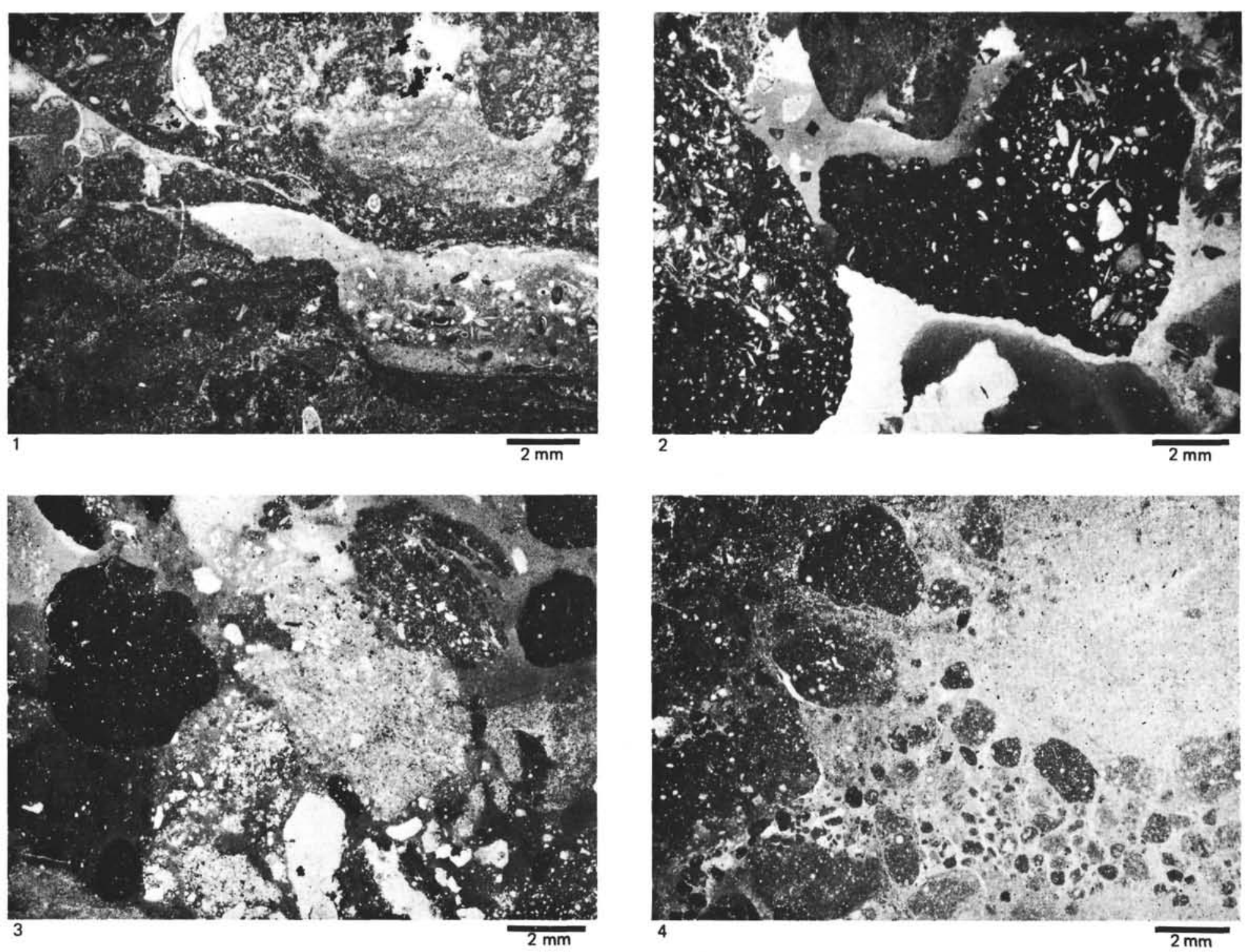

Plate 13. Selected facies types of Hole 547B. $(\times 7$.$) 1. Peloid crust cycle. The pelmicritic bindstone contains cavities subparallel to bedding and filled by bioclastic$ sediment with foraminifers such as Ophthalmidium and Lenticulina; lithified surfaces are grown by serpulids. Oxfordian, Sample 547B-10-1, 138-143 cm. 2. Gray limestone breccia. Rounded and subangular clasts of sandy bioclastic wackestones with siliceous sponge spicules and Involutina ticinensis Schweighauser derived from slope areas of the front of the Liassic shallow-water carbonate platform. Lias-Dogger?, Sample 547B-12-1, 35-39 cm. 3. Red limestone breccia. Polymicritic sandy floatstone composed of angular to subrounded clasts of bioturbated radiolarian peloid micrite, clayey micrite, quartzose micrite, and micritic sandstone floating in recrystallized micritic matrix containing large quartz grains and authigenous calcite crystals. Lias-Dogger?, Sample 547B-13-1, 118-122 sandstone floating in recrystallized micritic matrix containing large quartz grains and authigenous calcite crystals. Lias-Dogger?, Sample 547B-13-1, 118-122
$\mathrm{cm}$. 4. Nodular limestone. Subangular to rounded lithoclasts of radiolarian wackestone in recrystallized clayey carbonate matrix rich in fine-grained detrital quartz. Lias, Sample 547B-15,cc (9-12). 